Supporting Information for:

\title{
A Chemical Proteomics Approach for Profiling the NAD Interactome
}

Justina Šileikytėł, Sunil Sundalamł Larry L. David and Michael S. Cohen*

Department of Chemical Physiology and Biochemistry, Oregon Health and Science University, Portland, OR 97239

$\$$ These authors contributed equally

*email: cohenmic@ohsu.edu

\section{Table of Contents}

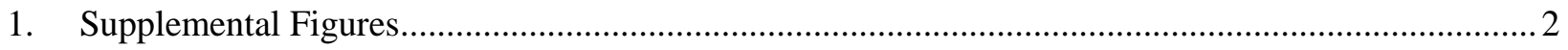

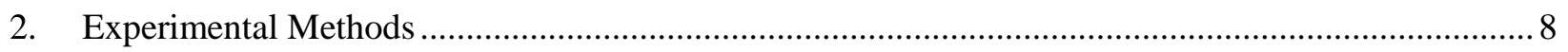

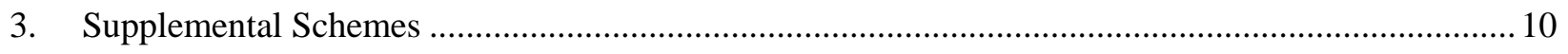

4. Chemical synthesis methods and compound characterization ................................................... 18 


\section{Supplemental Figures}

(a)

PARP-1

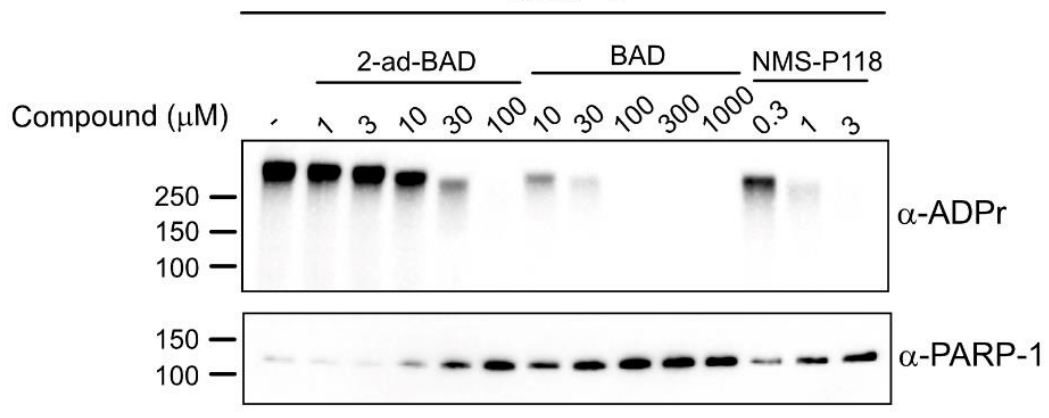

(b)

PARP-10

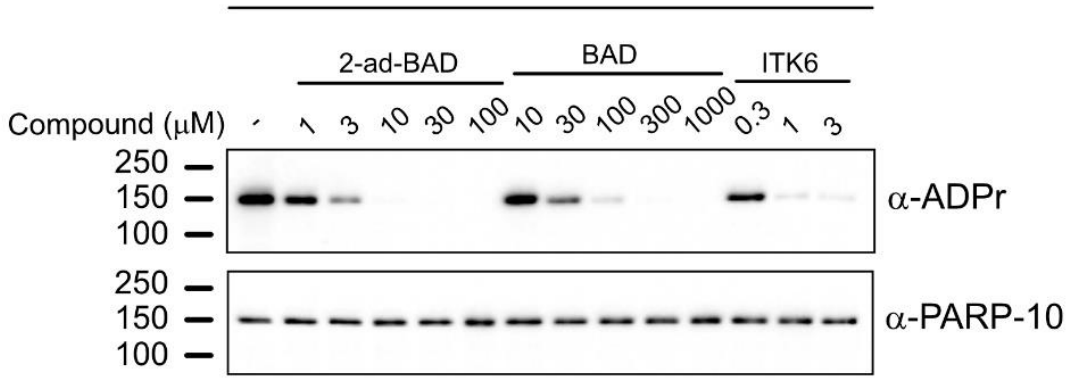

(c)

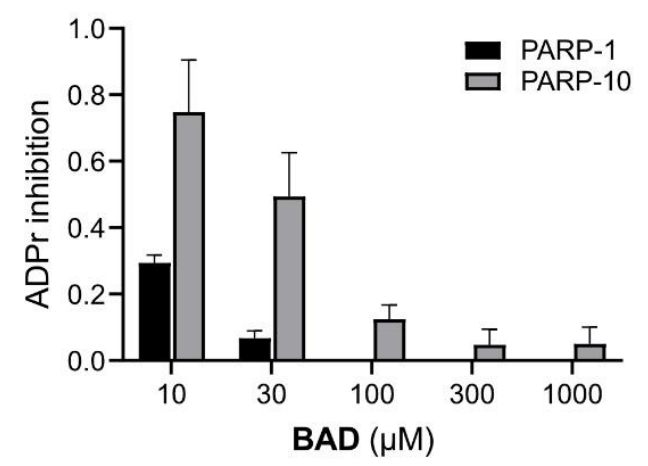

Figure S1. A clickable NAD ${ }^{+}$PAL probe (2-ad-BAD) inhibits PARP-1 and PARP-10 activity in concentration response. (a) $50 \mathrm{nM}$ of recombinant His6-PARP-1 was incubated with $10 \mu \mathrm{g} / \mathrm{mL}$ activated DNA in $100 \mathrm{mM} \mathrm{NaCl}, 50 \mathrm{mM}$ HEPES [pH 7.4], $4 \mathrm{mM} \mathrm{MgCl}_{2}, 0.2 \mathrm{mM}$ TCEP for $10 \mathrm{~min}$, then treated with indicated competitor (BAD or the PARP-1 inhibitor NMS-P118) for additional $10 \mathrm{~min} .50 \mu \mathrm{M} \mathrm{NAD}^{+}$ was then added to initiate auto-PARylation of PARP-1. After $10 \mathrm{~min}$, the reaction was quenched by addition of $4 \mathrm{x}$ Laemmli sample buffer and boiling at $95^{\circ} \mathrm{C}$ for $5 \mathrm{~min}$. Protein samples were separated by SDS-PAGE, transferred onto nitrocellulose and probed with indicated antibodies. (b) Experiments were performed essentially as in (a) with the exception that damaged DNA was omitted and the PARP-10 inhibitor ITK6 was used instead of NMS-P118. (c) Densitometry analyses of (b) and (c) comparing inhibitory effect of BAD on PARP-1 and PARP-10 auto-ADP-ribosylation. Data are mean \pm SEM of 3 independent experiments. 

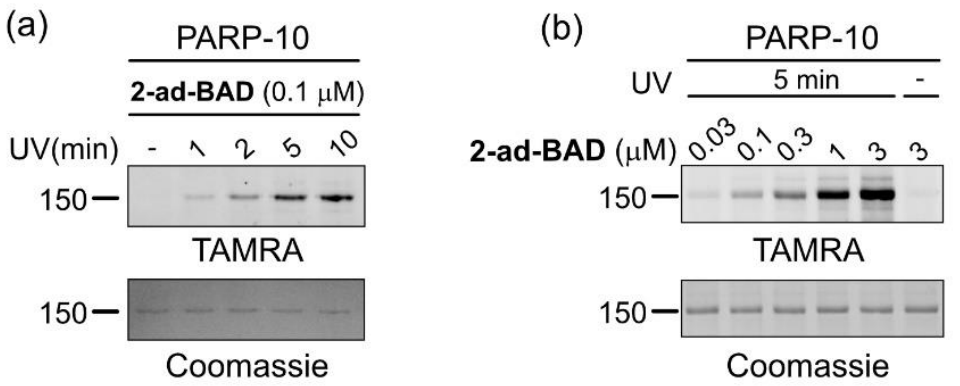

Figure S2. Photo-crosslinking of 2-ad-BAD to PARP-10 is both UV time- and dose-dependent. (a) PARP$10(250 \mathrm{nM})$ in $100 \mathrm{mM} \mathrm{NaCl}, 50 \mathrm{mM}$ HEPES [pH 7.4], $4 \mathrm{mM} \mathrm{MgCl}_{2}, 0.2 \mathrm{mM}$ TCEP was incubated with 2-ad-BAD for $10 \mathrm{~min}$ and then irradiated for indicated times. PARP-10 was coupled to tetramethylrhodamine azide (TAMRA-azide) using click chemistry, resolved by SDS-PAGE and subjected to in-gel fluorescence scanning. Coomassie stain was used for loading control. (b) Experiments were performed essentially as in (a) only that irradiation time was kept constant at 5 min and effects of increasing concentrations of 2-ad-BAD were studied. Data are representative of 2 independent experiments. 


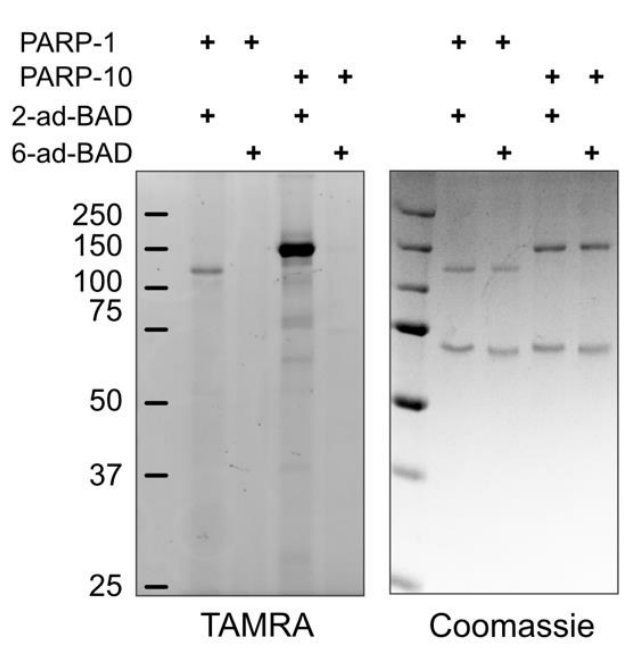

Figure S3. 6-ad-BAD does not label PARP-1 or PARP-10. Labeling experiments were performed as described in Figure S2b using $1 \mu \mathrm{M}$ of either 2- or 6-ad-BAD. 
(a)

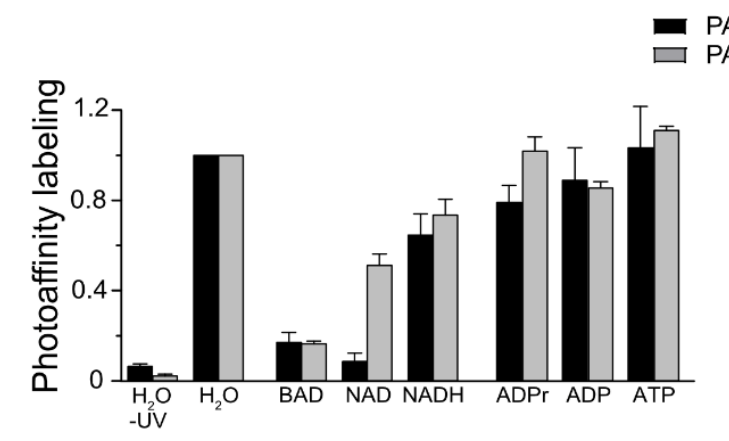

(b)

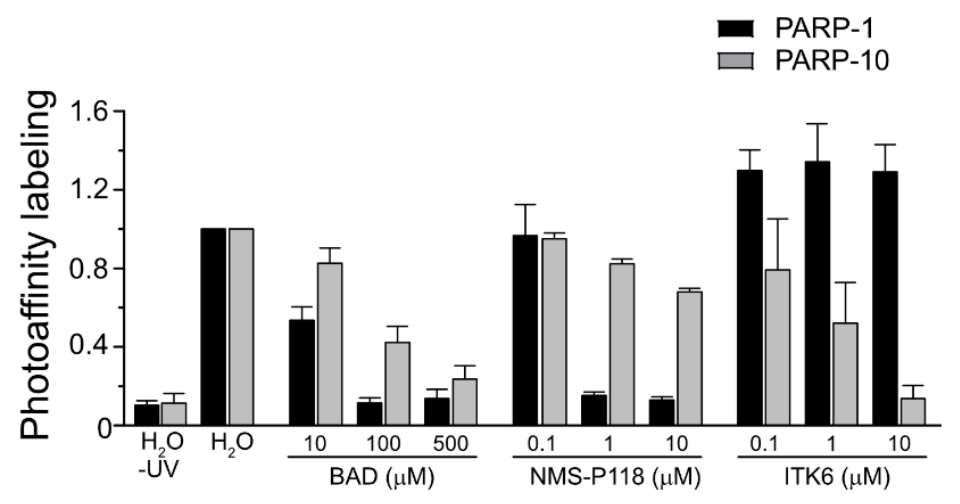

Figure S4. Densitometry analyses of Figure $3(a)$ panels $(a, b)$ comparing the inhibitory effect of nucleotides and (b) panels (c,d) comparing inhibitory effect of PARP inhibitors on PARP-1 and PARP-10 labelling by 2-ad-BAD. TAMRA in-gel fluorescence was normalized to Coomassie staining, except for PARP-1 NAD ${ }^{+}$ treated samples where relative to control TAMRA signal is reported due to auto-PARylation induced molecular weight shift and therefore not detectable Coomassie signal at PARP-1 molecular weight of $\sim 110$ $\mathrm{kDa}$. Data are mean $\pm \mathrm{SEM}$ of 3 independent experiments. 


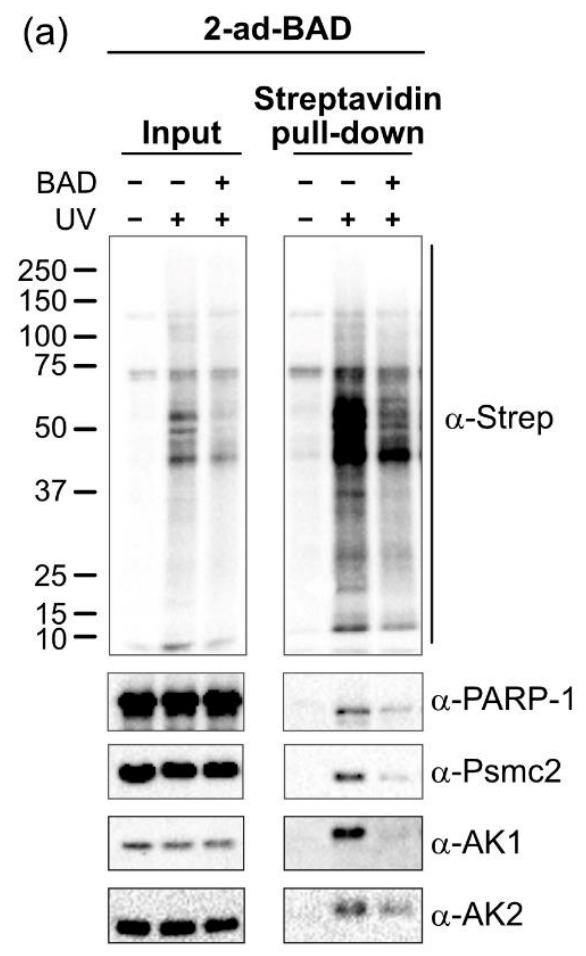

(b)

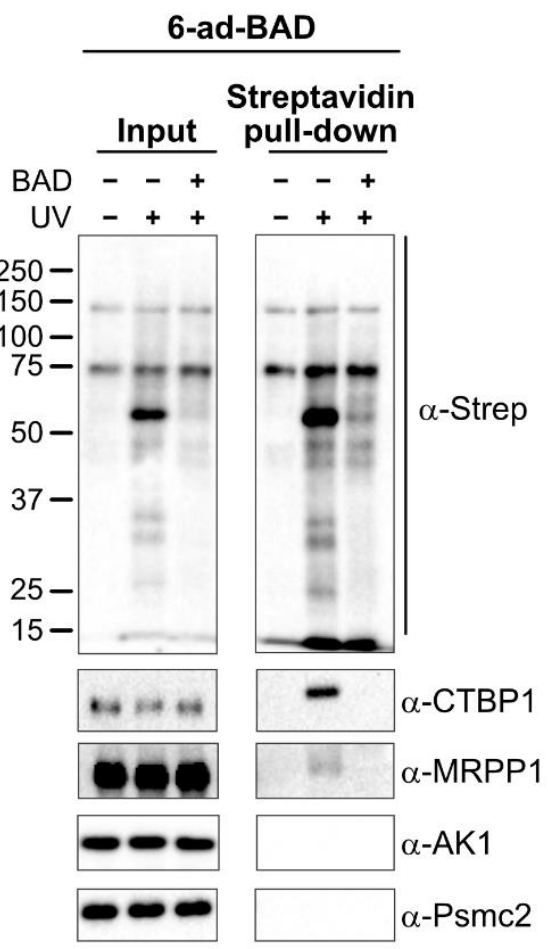

Figure S5. Validation of (a) 2-ad-BAD and (b) 6-ad-BAD targets identified in LC-MS/MS. HEK293T lysates were preincubated with $1 \mathrm{mM} \mathrm{BAD}$ for $10 \mathrm{~min}$ followed by $10 \mathrm{~min}$ incubation with $10 \mu \mathrm{M}$ of indicated probe. Samples were then UV irradiated for $5 \mathrm{~min}$ (or kept in the dark), coupled to desthiobiotinazide using click chemistry, enriched with streptavidin beads, resolved by SDS-PAGE and immunoblotted with indicated antibodies. 
(a)

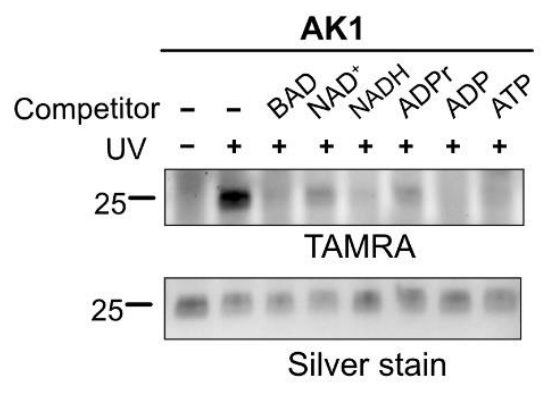

(b) AK1 Thermal stabilization

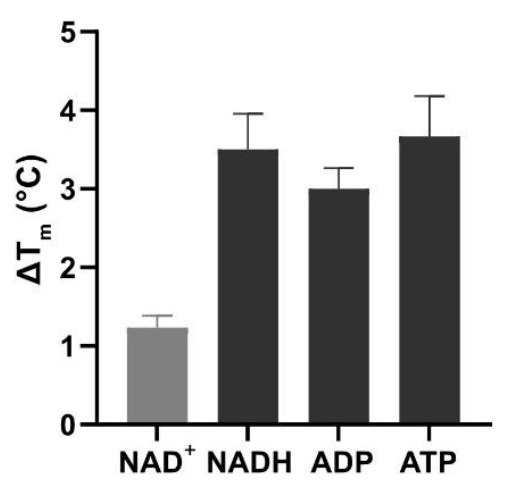

Figure S6. Validation of Adenylate kinase 1 (AK1) as a putative NAD + NADH binding protein. (a) 2-adBAD directly and specifically binds to AK1. Recombinant AK1 (500 nM) in $100 \mathrm{mM} \mathrm{NaCl}, 50 \mathrm{mM}$ HEPES [pH 7.4], $4 \mathrm{mM} \mathrm{MgCl}, 0.2 \mathrm{mM}$ TCEP was incubated with $150 \mu \mathrm{M}$ of indicated competitor molecule for $10 \mathrm{~min}$, followed by $10 \mathrm{~min}$ treatment with $0.3 \mu \mathrm{M}$ 2-ad-BAD. Samples were then subjected to UV light for 5 min, conjugated to TAMRA using Click chemistry, separated by SDS-PAGE and in-gel fluorescence was recorded. Silver staining was used to demonstrate comparable protein loading. (b) A differential scanning fluorimetry assay is supportive of NADH as novel AK1 ligand. Recombinant AK1 $(0.1 \mathrm{mg} / \mathrm{mL})$ in $100 \mathrm{mM} \mathrm{NaCl}, 50 \mathrm{mM}$ HEPES, $\mathrm{pH} 7.4,4 \mathrm{mM} \mathrm{MgCl}_{2}$, 7.5x SYPRO Orange was tested for thermal stability in the absence or presence of indicated nucleotides at $1 \mathrm{mM}$. Ordinate reports on the difference of melt peak temperature prompted by indicated treatments. Data are mean \pm SEM of 3 independent experiments. 


\section{Experimental Methods}

\section{Protein expression and purification}

Full length His $_{6}$-PARP-1 and His 6 -SUMO-PARP-10 proteins we expressed and purified as previously described $^{1,2}$.

\section{In vitro PARP-1 and PARP-10 activity assay}

PARP-1 or PARP-10 were diluted to $20 \mathrm{nM}$ in reaction buffer consisting of $100 \mathrm{mM} \mathrm{NaCl}, 50 \mathrm{mM}$ Hepes, $4 \mathrm{mM} \mathrm{MgCl}, 0.2 \mathrm{mM}$ TCEP [pH 7.4] and - in assays of PARP-1 only - $10 \mu \mathrm{g} / \mathrm{mL}$ of activated calf thymus DNA (Sigma-Aldrich D4522) followed by 10 min incubation with $\mathrm{ddH}_{2} \mathrm{O}$ or indicated concentrations of BAD, 2-ad-BAD, NMS-P118 (Selleckchem) or ITK6 ${ }^{2}$ at RT. The ADP-ribosylation reactions were started by addition of $50 \mu \mathrm{M} \mathrm{NAD}^{+}$, let to proceed for $10 \mathrm{~min}$ RT before quenching with $4 \mathrm{x}$ Laemmli sample buffer and boiling for $5 \mathrm{~min}$ at $95^{\circ} \mathrm{C}$.

\section{In vitro photocrosslinking and Click chemistry}

Treatments. Recombinant PARP-1 (250 nM), PARP-10 (250 nM) or AK1 (500 nM; Novus Biologicals) were diluted in $100 \mathrm{mM} \mathrm{NaCl}, 50 \mathrm{mM}$ HEPES [pH 7.4], $4 \mathrm{mM} \mathrm{MgCl}, 0.2 \mathrm{mM}$ TCEP. PARP-1 reactions also contained $10 \mu \mathrm{g} / \mathrm{mL}$ of activated calf thymus DNA (Sigma-Aldrich D4522), unless otherwise noted. In experiments reported in Figure 2, the samples were treated with $0.1 \mu \mathrm{M}$ 2-ad-BAD or ad-olaparib for 10 min. In competition experiments reported in Figure 3 and Figure S3, samples were first treated with 150 $\mu \mathrm{M}$ of indicated nucleotides for 10 minute and then with $0.3 \mu \mathrm{M} 2$-ad-BAD for additional $10 \mathrm{~min}$. All treatments occurred at RT. Samples were then kept in the dark or irradiated for 5 min in the RPR-100 Photochemical Reactor (Rayonet) equipped with $350 \mathrm{~nm}$ lamps at $4{ }^{\circ} \mathrm{C}$. The 2-ad-BAD concentrations and UV irradiation time were selected based on data obtained in experiments reported in Figure S2.

Click Chemistry. $25 \mu \mathrm{L}$ of each sample was mixed with $5 \mu \mathrm{L}$ of fatty acid free BSA and SDS to give a final Click reaction concentration of $1 \mathrm{mg} / \mathrm{mL}$ and $1 \%$, respectively. Click reactions were started by adding 15 $\mu \mathrm{L}$ of PBS based $3 \mathrm{x}$ click reaction mix (final 1x concentrations shown): $100 \mu \mathrm{M}$ Tris[(1-benzyl-1H1,2,3triazol-4-yl)methyl]amine (TBTA, Click Chemistry Tools), $\quad 1 \quad \mathrm{mM} \quad \mathrm{CuSO}_{4}, \quad 40 \quad \mu \mathrm{M}$ tetramethylrhodamine (TAMRA)-azide (Click Chemistry Tools), $1 \mathrm{mM}$ Tris(2-carboxyethyl)phosphine hydrochloride (TCEP, Thermo Fisher) and 5\% tert-Butyl alcohol to each sample, and let to proceed for $1 \mathrm{~h}$ at RT while gently shaking. Reactions were stopped by adding 4x Laemmli sample buffer and boiling at $95^{\circ} \mathrm{C}$ for $5 \mathrm{~min}$.

In gel fluorescence and staining. Samples were loaded to 10 or $12 \%$ SDS-polyacrylamide gels and run until the dye front left the gel. In-gel fluorescence was detected with ChemiDoc XRS+ (Biorad) using Rhodamine filter and then the gels were stained with Coomassie blue or Silver using standard protocols. 


\section{Photocrosslinking in cell lysates, Click chemistry, immunocapture and sample preparation for LC- MS/MS}

Cell culture and lysis. HEK 293T cells were grown in DMEM (Gibco) + 10\% fetal bovine serum (Sigma) at $37^{\circ} \mathrm{C}$ and $5 \% \mathrm{CO}_{2}$ to confluence. Cells were lysed on ice in $150 \mathrm{mM} \mathrm{NaCl}, 50 \mathrm{mM}$ HEPES [pH 7.4], 5 $\mathrm{mM} \mathrm{MgCl}, 10 \%$ Glycerol, $0.1 \% \mathrm{NP}-40$ and EDTA-free protease inhibitor cocktail (Roche) for 30 min on ice. The lysate was cleared by centrifugation at $10,000 \mathrm{~g}$ for $15 \mathrm{~min}$ at $4^{\circ} \mathrm{C}$ and then desalted with $\mathrm{Zeba}{ }^{\mathrm{TM}}$ Spin Desalting Columns (Thermo Fisher) according to manufacturer's instructions. Protein concentration was determined with Bio-Rad Protein assay and the lysate was diluted in lysis buffer to $2 \mathrm{mg} / \mathrm{ml}$.

Treatments. Cell lysates were first treated with $\mathrm{ddH}_{2} \mathrm{O}$ or $1 \mathrm{mM}$ BAD for $10 \mathrm{~min}$ at RT and then with 10 $\mu \mathrm{M}$ 2-ad-BAD or 6-ad-BAD for additional $10 \mathrm{~min}$. Samples were then kept in the dark or irradiated for 5 min in the RPR-100 Photochemical Reactor (Rayonet) equipped with $350 \mathrm{~nm}$ lamps at $4^{\circ} \mathrm{C}$.

Click Chemistry. SDS (final concentration $0.05 \%$ ) was added to $960 \mu \mathrm{L}$ of each sample, followed by conjugation to desthiobiotin by adding $480 \mu \mathrm{L}$ of PBS based 3x Click reaction mixture containing (final concentrations): $100 \mu \mathrm{M}$ Tris[(1-benzyl-1H-1,2,3triazol-4-yl)methyl]amine (TBTA, Click Chemistry Tools), $1 \mathrm{mM} \mathrm{CuSO}$, $200 \mu \mathrm{M}$ desthioBiotin-peg3-azide (Click Chemistry Tools), $1 \mathrm{mM}$ Tris(2carboxyethyl)phosphine hydrochloride (TCEP, Thermo Fisher) and 5\% tert-Butyl alcohol. Reactions were let to proceed for $1 \mathrm{~h}$ at RT while gently shaking and then stopped by adding 9 parts of cold methanol. Protein was precipitated overnight at $-20^{\circ} \mathrm{C}$. Samples were then centrifuged $3,500 \mathrm{~g}$ for $10 \mathrm{~min}$ at $4^{\circ} \mathrm{C}$, aqueous/MeOH solution was removed and protein precipitates were washed 3 times as follows: pellets were re-suspended in $1 \mathrm{ml}$ cold $\mathrm{MeOH}$ by pipetting and sonication, re-precipitated for $15 \mathrm{~min}$ at $-20^{\circ} \mathrm{C}$ and then spun at 10,000 $\mathrm{g}$ for $10 \mathrm{~min}$ at $4^{\circ} \mathrm{C}$. After the final wash, the pellets were air dried at RT for $\sim 10 \mathrm{~min}$ and re-solubilized in $700 \mu \mathrm{L} 8 \mathrm{M}$ urea in $0.1 \mathrm{M}$ TEAB by bath sonication and transferred to LoBind microcentrifuge tubes (Eppendorf).

Immunoprecipitation. Biotinylated proteins were enriched with streptavidin agarose resin as follows: 2.1 $\mathrm{mL}$ of $0.1 \mathrm{M}$ TEAB was added to protein solutions to reduce the urea concentration to $2 \mathrm{M}$. Then, $350 \mu \mathrm{L}$ of streptavidin beads (50\% slurry; Thermo Fisher 20349) were preequilibrated with $1 \%$ NP-40 in $0.1 \mathrm{M}$ TEAB and a total of $2.8 \mathrm{~mL}$ of that solution was added to protein samples overnight at $4^{\circ} \mathrm{C}$. Beads were then spun $2,000 \mathrm{~g}$ for $5 \mathrm{~min}$ at $4^{\circ} \mathrm{C}$, supernatant removed and the beads were washed $3 \mathrm{x}$ each with $1 \mathrm{~mL}$ of: (i) $4 \mathrm{M}$ urea in $0.1 \mathrm{M} \mathrm{TEAB}$, (ii) $1 \% \mathrm{NP}-40$ in PBS, (iii) PBS and (iv) $50 \mathrm{mM}$ ammonium bicarbonate; centrifuging $2000 \mathrm{~g}$ for 3 min each time.

Sample preparation for LC-MS/MS analysis. After final wash, beads with enriched biotinylated proteins were suspended in $700 \mu \mathrm{L} 8 \mathrm{M}$ urea in $0.1 \mathrm{M} \mathrm{TEAB}$ and thiols were reduced with $1.4 \mathrm{mg} / \mathrm{mL}$ dithiothreitol (DTT; Fisher) followed by alkylation with $3.4 \mathrm{mg} / \mathrm{mL}$ iodocetamide (Calbiochem), both incubations occurred for $45 \mathrm{~min}$ at $37^{\circ} \mathrm{C}$ while gently shaking. Free iodacetamide was quenched with $1.4 \mathrm{mg} / \mathrm{mL}$ DTT for $30 \mathrm{~min}$ at RT while gently shaking. Then beads were spun as above, washed with $1 \mathrm{~mL} 2 \mathrm{M}$ urea in 0.1 $\mathrm{M}$ TEAB and re-suspended in $400 \mu \mathrm{L}$ of the same buffer supplemented $1 \mathrm{mM} \mathrm{CaCl}_{2}$ and $2 \mu \mathrm{g}$ sequencing grade trypsin (Promega). Proteins were digested $37^{\circ} \mathrm{C}$ overnight while shaking. Samples were then transferred to centrifuge columns (Thermo Fisher 69705) and digested peptides were collected to LoBind microcentrifuge tubes upon spinning for $3 \mathrm{~min}$ at $2000 \mathrm{~g}$. MS grade formic acid was then added to $5 \%$ and samples were kept at $-20^{\circ} \mathrm{C}$ till LC-MS/MS analysis.

\section{LC-MS/MS analysis}

Following digestion, all samples were taken to dryness by vacuum centrifugation. Supernatants from onbead digests were dissolved in $100 \mu \mathrm{L}$ of $5 \%$ formic acid and after $0.22 \mu \mathrm{m}$ filtering of dissolved samples 
using Millipore Ultrafree-CL centrifugal filters, $20 \mu \mathrm{L}$ of each digest were separated using a Dionex RSLC UHPLC system, then delivered to a QExactive HF (Thermo Scientific) mass spectrometer using electrospray ionization with a Nano Flex Ion Spray Source fitted with a $20 \mu \mathrm{m}$ stainless steel nano-bore emitter spray tip and $1.0 \mathrm{kV}$ source voltage. Xcalibur version 4.0 was used to control the system. Samples were applied at $10 \mu \mathrm{L} / \mathrm{min}$ to a Symmetry C18 trap cartridge (Waters) for $10 \mathrm{~min}$, then switched onto a 75 $\mu \mathrm{m} \times 250 \mathrm{~mm}$ NanoAcquity BEH $130 \mathrm{C} 18$ column with $1.7 \mu \mathrm{m}$ particles (Waters) using mobile phases water (A) and acetonitrile (B) containing $0.1 \%$ formic acid, 7.5-30\% acetonitrile gradient over 60 min, and $300 \mathrm{~nL} / \mathrm{min}$ flow rate. Survey mass spectra were acquired over m/z 375-1400 at 120,000 resolution (m/z 200) and data-dependent acquisition selected the top 10 most abundant precursor ions for tandem mass spectrometry by HCD fragmentation using an isolation width of $1.2 \mathrm{~m} / \mathrm{z}$, normalized collision energy of 30 , and a resolution of 30,000. Dynamic exclusion was set to auto, charge state for MS/MS +2 to +7, maximum ion time $100 \mathrm{~ms}$, minimum AGC target of $3 \times 10^{6}$ in MS1 mode and $5 \times 10^{3}$ in MS2 mode. Comet (v. 2016.01, rev. 2) ${ }^{3}$ was used to search MS2 Spectra against an April. 2020 version of a uniprot FASTA protein database containing canonical Homo sapien sequences, concatenated sequence-reversed entries to estimate error thresholds and 179 common contaminant sequences and their reversed forms. The database processing used python scripts available at https://github.com/pwilmart/fasta utilities.git and Comet results processing used the PAW pipeline2 from https://github.com/pwilmart/PAW_pipeline.git. Comet searches for all samples was performed with trypsin enzyme specificity with monoisotopic parent ion mass tolerance set to $1.25 \mathrm{Da}$ and monoisotopic fragment ion mass tolerance set at $1.0005 \mathrm{Da}$. A static modification of $+57.02146 \mathrm{Da}$ added to all cysteine residues and a variable modification of $+15.9949 \mathrm{Da}$ on Methionine residues. Linear discriminant transformation was used to improve the identification sensitivity from the Comet analysis ${ }^{4,5}$. Comet scores were combined into linear discriminant function scores, and discriminant score histograms created separately for each peptide charge state $(2+, 3+$, and $4+)$. Separate histograms were created for matches to forward sequences and for matches to reversed sequences for all peptides of seven amino acids or longer. The score histograms of reversed matches were used to estimate peptide false discovery rates (FDR) and set score thresholds for each peptide class. The overall peptide FDR for the analysis was $2.67 \%$, and the overall protein FDR was $0.6 \%$.

\section{LC-MS/MS target validation by western blotting}

Samples were processed exactly as for LC-MS/MS experiment only that $1 / 5$ of the volumes were used, and procedure was stopped after final bead wash after immunoprecipitation. The enriched biotinylated proteins were eluted by suspending them in 2x Laemmli sample buffer supplemented with $5 \mathrm{mM}$ biotin and boiled at $95^{\circ} \mathrm{C}$ for $5 \mathrm{~min}$.

\section{SDS-PAGE, Wester blotting and quantification}

Samples were run on $10 \%$ or $12 \%$ acrylamide gels for $\sim 1 \mathrm{~h}$ at $180 \mathrm{~V}$ in Mini-PROTEAN Tetra cell (Biorad). The proteins were then transferred onto nitrocellulose membranes using Trans-Blot Turbo system (Biorad), the membranes were blocked with $5 \%$ milk in PBST for $1 \mathrm{~h} \mathrm{RT}$ and then probed overnight at $4{ }^{\circ} \mathrm{C}$ for panADP-ribose (1:1000; Cell signaling technology cat\# 83732), PARP-1 (1:3000; Cell signaling technology cat\# 9532), PARP-10 (1:1000; Bethyl laboratories cat\# A300-665A), Psmc2 (1:1000; Bethyl laboratories cat\# A303-822A), AK1 (1:500; Proteintech cat\# 14978-1-AP), AK2 (1:1000; Proteintech cat\# 11014-1AP), CTBP1 (1:1000; Bethyl laboratories cat\# A300-338A) or MRPP1 (1:500; Bethyl laboratories cat\# A304-390A). Anti-streptavidin-horseradish peroxidase (1:5000; Jackson Immuno research laboratories cat\# 016-030-084) was incubated for 25 min RT. Rabbit secondary antibody was from Jackson Immuno research laboratories (cat\# 111-035-144). Membranes were developed with ECL Western Blotting Substrate (Thermo Scientific) using Biorad ChemiDoc MP. Band intensities we quantified with ImageJ. 


\section{Differential Scanning fluorimetry (DSF)}

Differential scanning fluorimetry was used to detect the AK1-ligand interaction. Experiments were performed with $0.1 \mathrm{mg} / \mathrm{mL}$ AK1 (Novus Biologicus cat\# NBP1-50855) in $100 \mathrm{mM} \mathrm{NaCl}, 50 \mathrm{mM}$ HEPES [pH 7.4], $4 \mathrm{mM} \mathrm{MgCl}_{2}$, and 7.5x SYPRO ORANGE (Life technologies cat\# S6650). AK1 thermal stability upon treatment with $\mathrm{ddH}_{2} \mathrm{O}, \mathrm{ATP}, \mathrm{ADP}, \mathrm{NAD}^{+}$or $\mathrm{NADH}, 1 \mathrm{mM}$ each, was measured on Biorad RT-PCR thermocycler using Cal Orange 560 filter. The thermocycler settings for melting curve determination were as follows: $2 \mathrm{~min}$ hold at $20^{\circ} \mathrm{C}$, ramp from $20^{\circ} \mathrm{C}$ to $99^{\circ} \mathrm{C}$ (increment $0.5^{\circ} \mathrm{C}$ for $30 \mathrm{~s}$ ) and then hold at $99^{\circ} \mathrm{C}$ for $2 \mathrm{~min}$. The melting temperature $\left(\mathrm{T}_{\mathrm{m}}\right)$ for each sample was determined by calculating first derivative of the fluorescence $(\mathrm{d}(\mathrm{RFU}) / \mathrm{dT})$ and shift in thermal stability $\left(\Delta \mathrm{T}_{\mathrm{m}}\right)$ was calculated by subtracting vehicle treated sample $\mathrm{T}_{\mathrm{m}}$ from ligand-treated sample $\mathrm{T}_{\mathrm{m}}$. 


\section{Supplemental Schemes}

\section{$\underline{\text { Scheme S1: Synthesis of 2-Diaziridyl alkyl AMP morpholidate }}$}
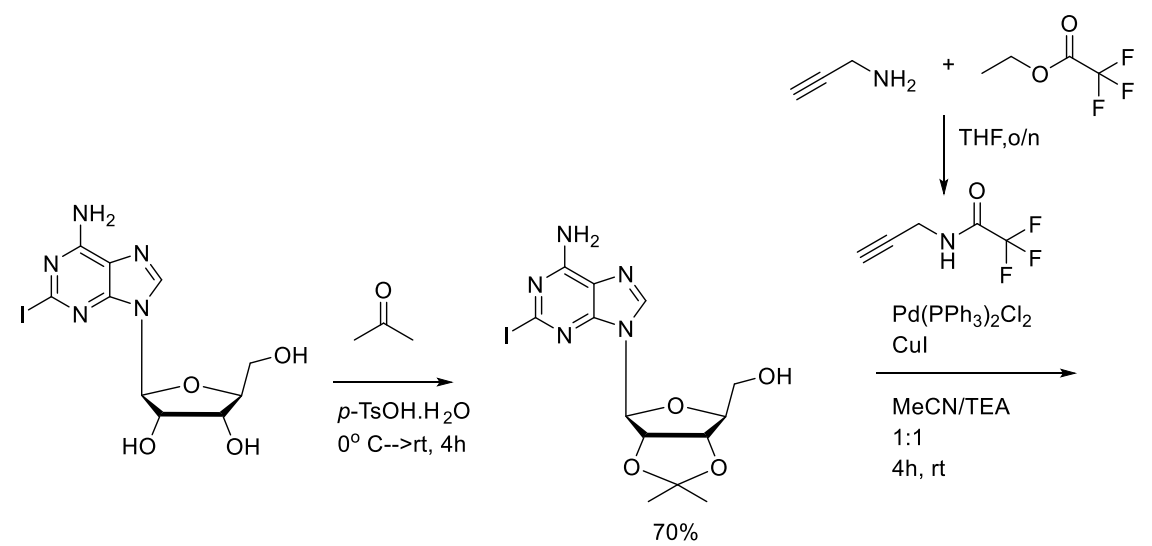
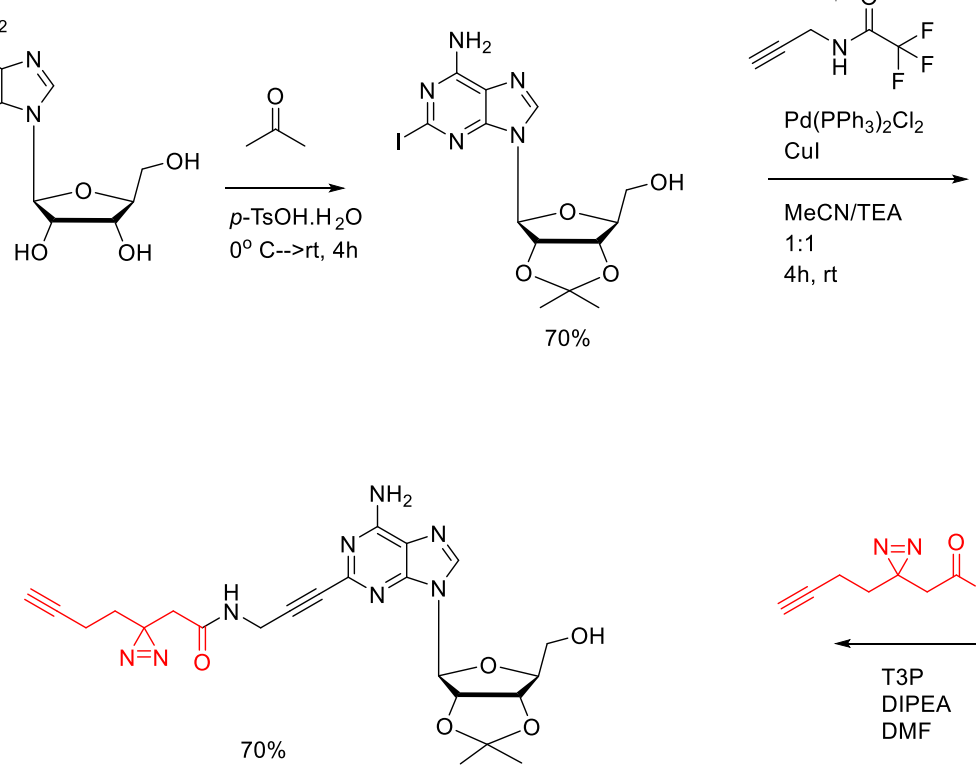

$\mathrm{POCl}_{3}$

TEA, THF

$\checkmark 0^{\circ} \mathrm{C}, 20 \mathrm{mins}$
$4 h, r t$

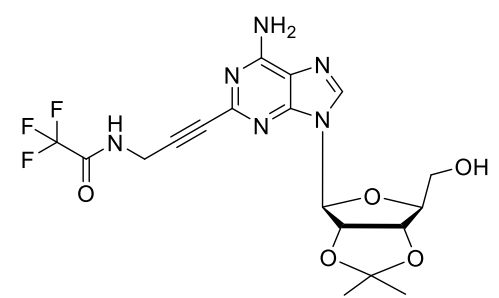

$67 \%$
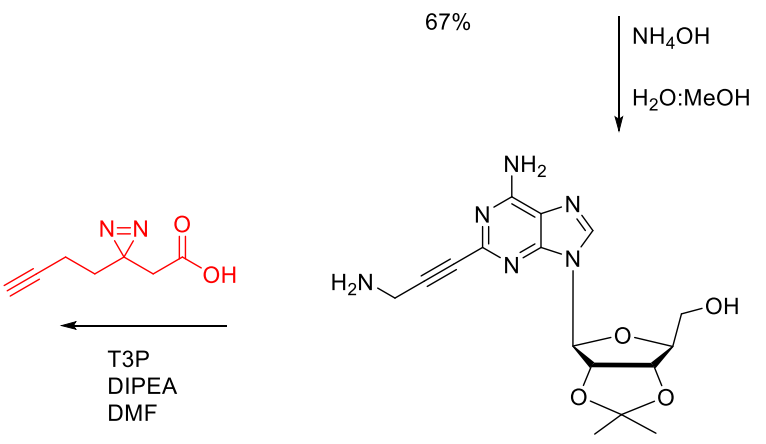

quantitative
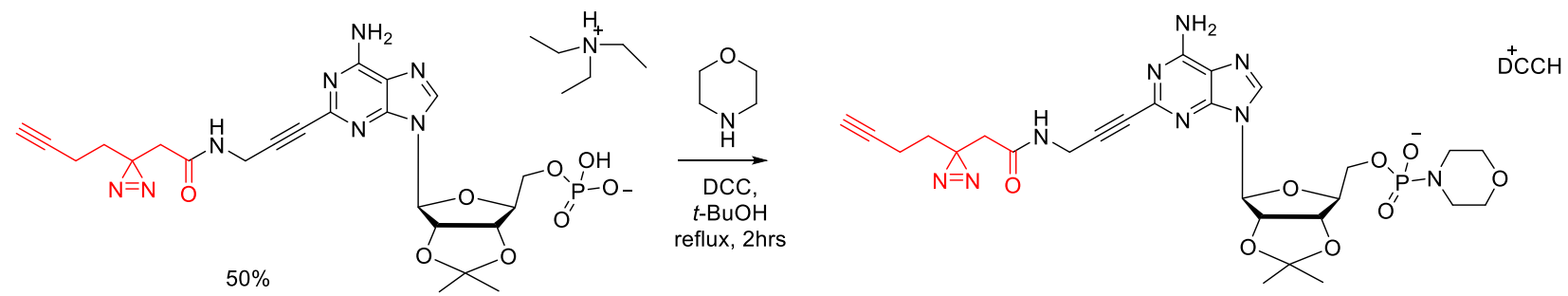

$96 \%$ 


\section{Scheme S2: Synthesis of the linker}

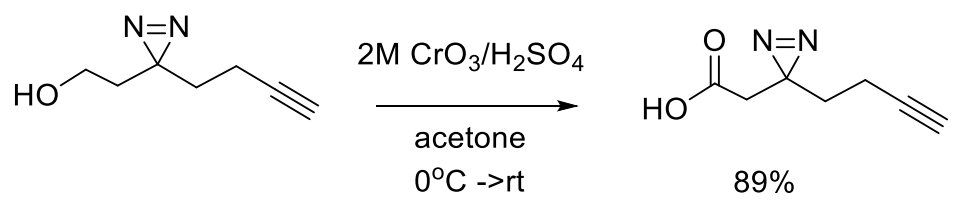

\section{Scheme S3: Synthesis of Benzamide riboside monophosphate}
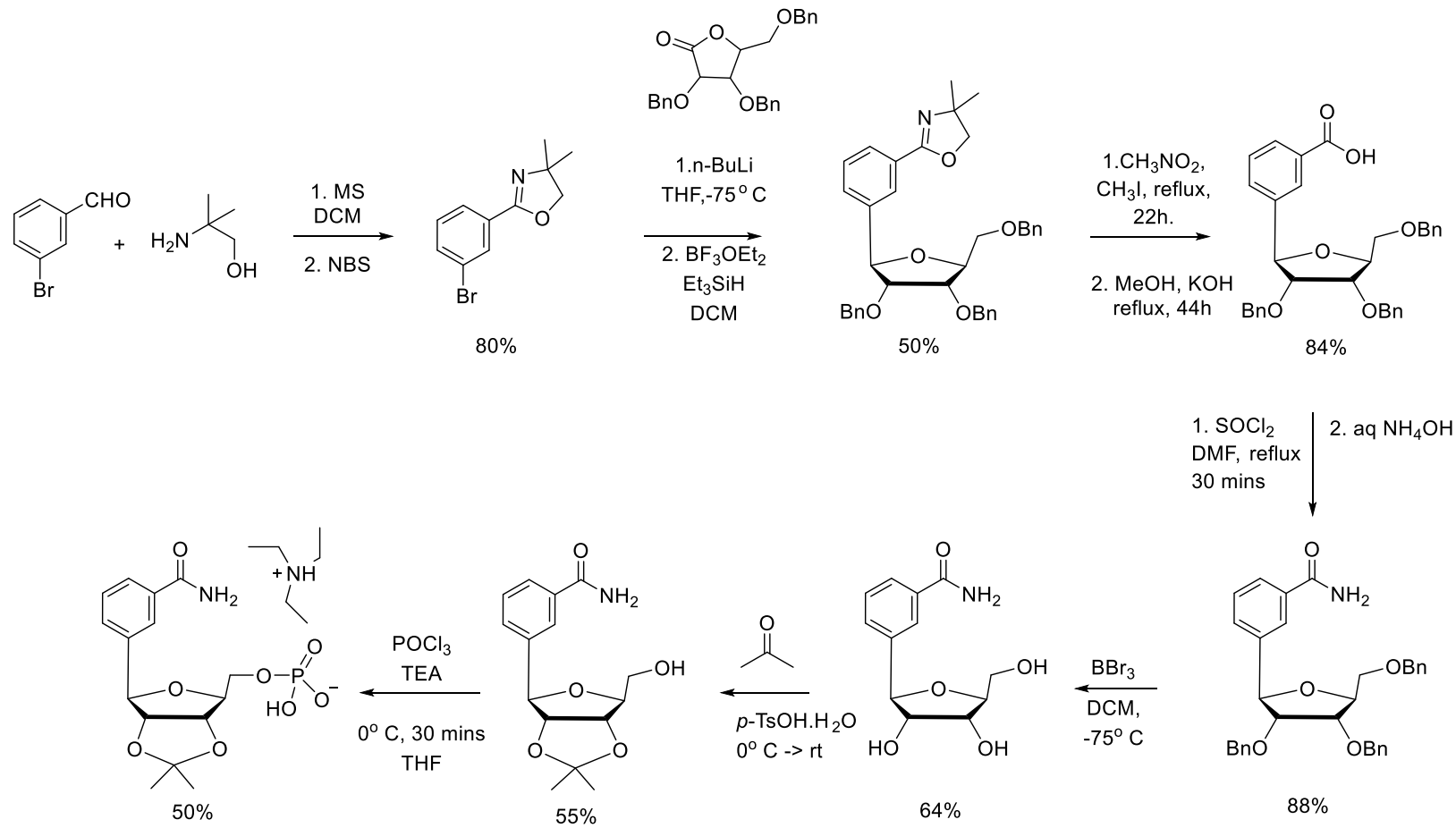


\section{Scheme S4: Synthesis of 2-ad-BAD}
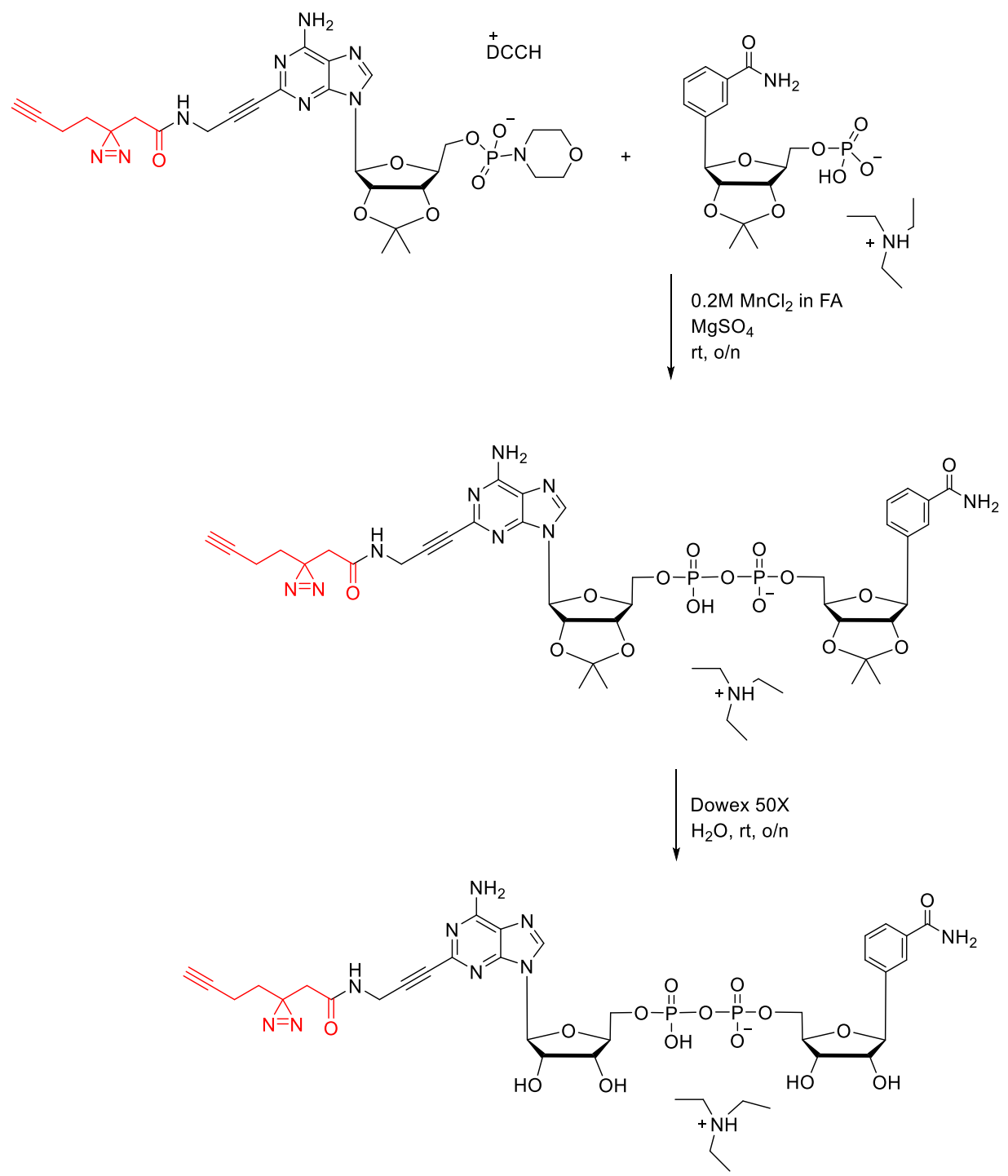
Scheme S5: Synthesis of 6-Diaziridyl alkyl AMP morpholidate

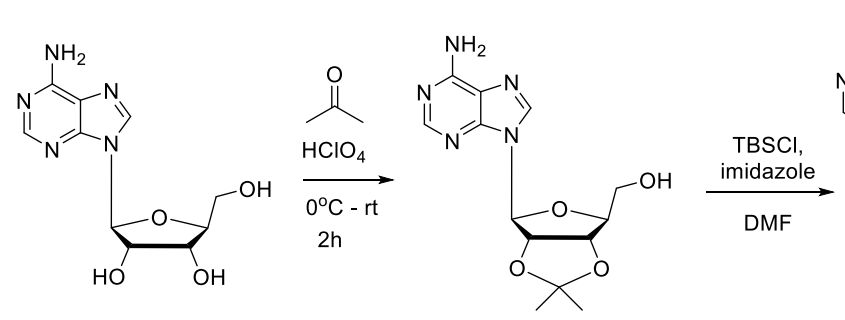

$94 \%$

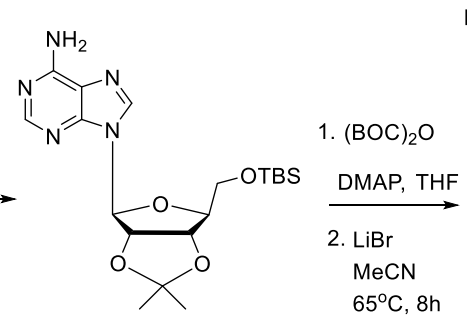

$95 \%$

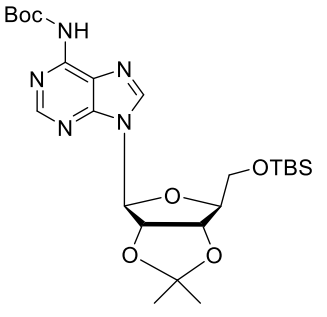

$47 \%$

over 2 steps

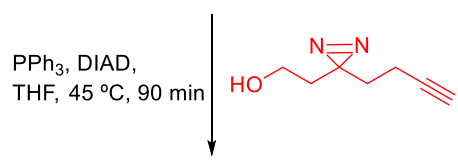

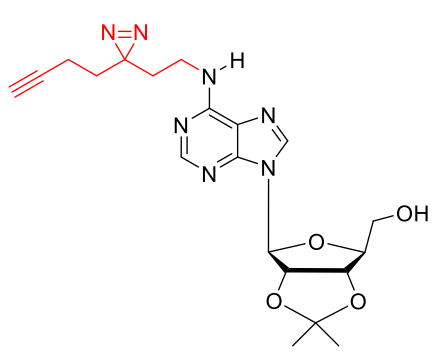

$50 \%$

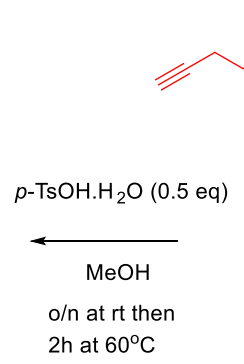

$2 \mathrm{~h}$ at $60^{\circ} \mathrm{C}$

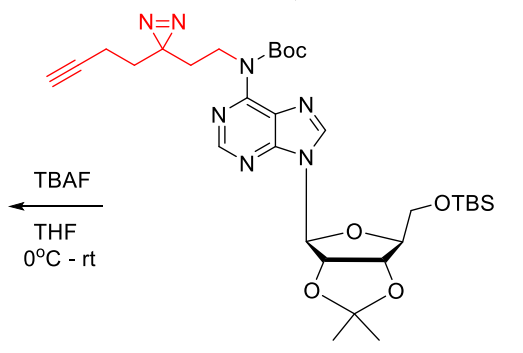

$80 \%$

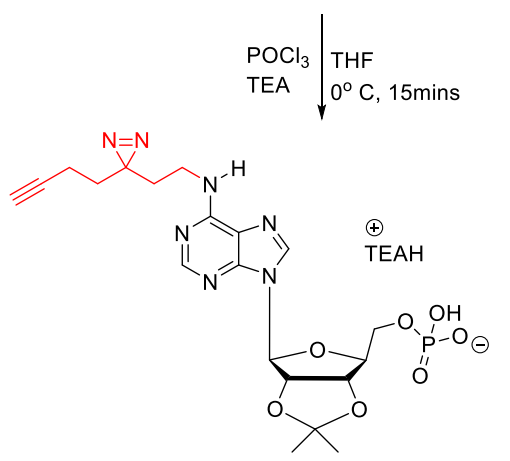

$44 \%$

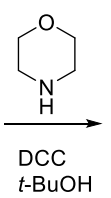

$t$-BuOH

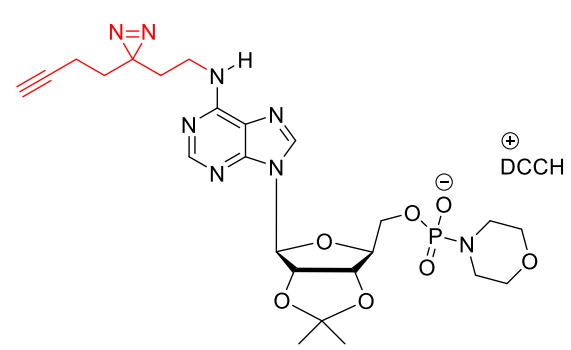

quantitative 
Scheme S6: Synthesis of 6-ad BAD
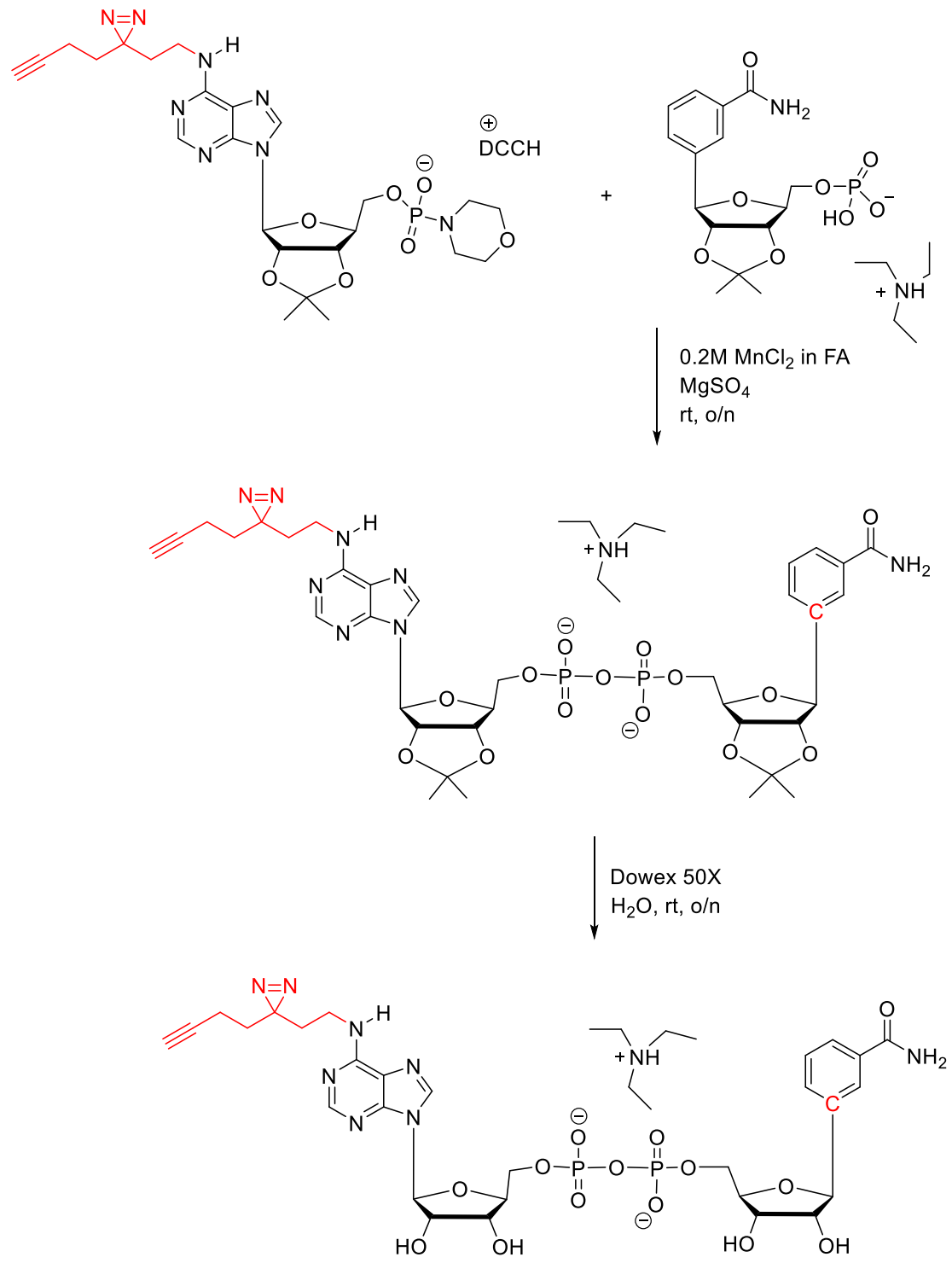


\section{Scheme S7: Synthesis of BAD}

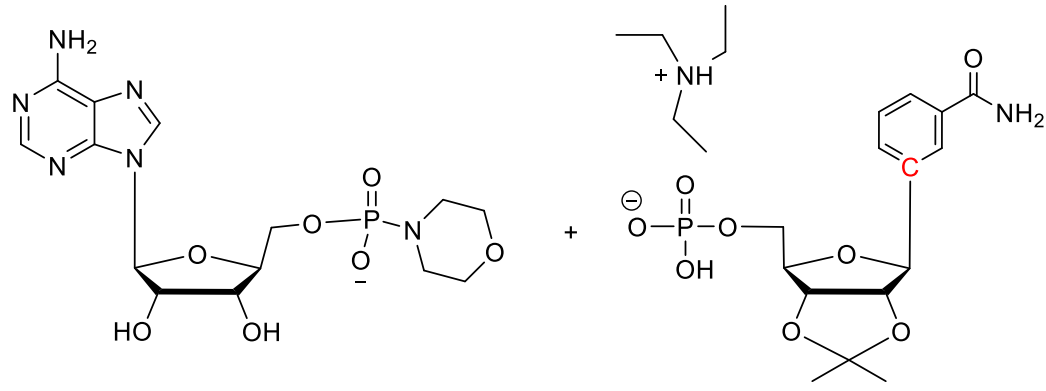

$$
\begin{array}{l|l}
\begin{array}{l}
0.2 \mathrm{M} \mathrm{MnCl}_{2} \\
\mathrm{MgSO}_{4} \\
\mathrm{rt}, \mathrm{o} / \mathrm{n}
\end{array} & \begin{array}{l}
\text { DOWEX-50X } \\
\mathrm{H}_{2} \mathrm{O}, \mathrm{rt} \mathrm{o} / \mathrm{n}
\end{array}
\end{array}
$$

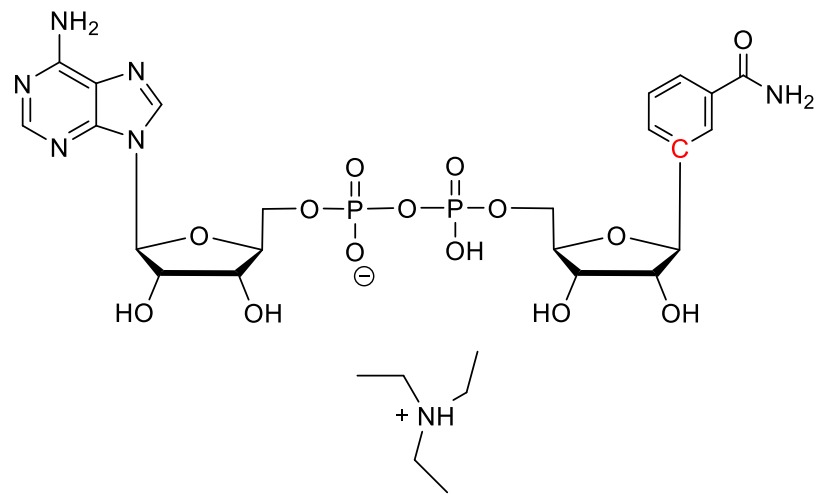

\section{Scheme S8: Synthesis of ad-olaparib}

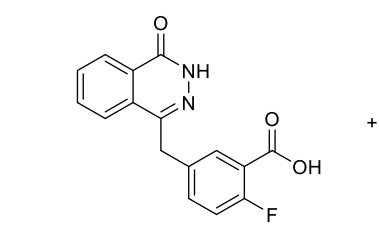

2-fluoro-5-((4-oxo-3,4-dihydrophthalazin1-yl)methyl)benzoic acid<smiles>CC(C)(C)OC(=O)N1CCNCC1</smiles>
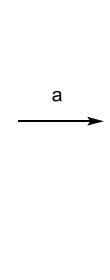

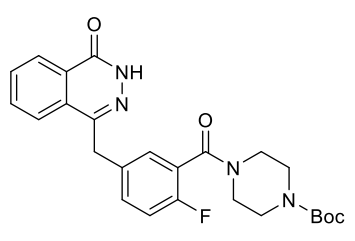

1
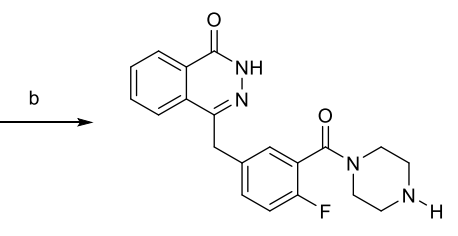

2<smiles>C#CCCC1(CCOC(=O)Oc2ccc([N+](=O)[O-])cc2)N=N1</smiles>
(i)

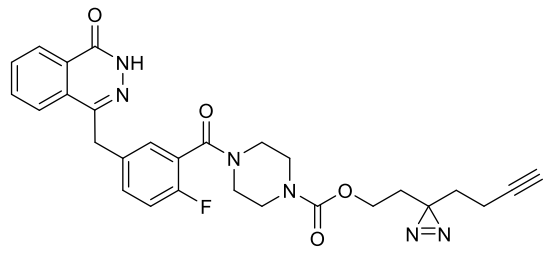

3

a. Propyl-phosphonic andydride (T3P), DIPEA, DMF, 84\% yield. b. $4 \mathrm{~N} \mathrm{HCl/Dioxane,} \mathrm{EtOH,} 70 \%$ yield.
c.i, TEA DMF, O/N, $89 \%$ yield 


\section{Chemical synthesis methods and compound characterization}

\section{General methods}

${ }^{1} \mathrm{H}$ NMR were recorded on a Bruker DPX spectrometer at $400 \mathrm{MHz}$. Chemical shifts are reported as parts per million (ppm) downfield from an internal tetramethylsilane standard or solvent references. For air- and water-sensitive reactions, glassware was oven-dried prior to use and reactions were performed under argon. Dichloromethane, dimethylformamide, and tetrahydrofuran were dried using the solvent purification system manufactured by Glass Contour, Inc. (Laguna Beach, CA). All other solvents were of ACS chemical grade (Fisher Scientific) and used without further purification unless otherwise indicated. Commercially available starting reagents were used without further purification. Analytical thin-layer chromatography was performed with silica gel 60 F254 glass plates (SiliCycle). Flash column chromatography was conducted with either pre-packed Redisep Rf normal/reverse phase columns Teledyne ISCO) or selfpacked columns containing 200-400 mesh silica gel (SiliCycle) on a Combiflash Companion purification system (Teledyne ISCO). High performance liquid chromatography (HPLC) was performed on a Varian Prostar 210 (Agilent) with a flow rate of $20 \mathrm{ml} / \mathrm{min}$ using Polaris 5 C18-A columns $(150 \mathrm{x} 4.6 \mathrm{~mm}, 3 \mu \mathrm{m}$ analytical, $150 \times 21.2 \mathrm{~mm}, 5 \mu \mathrm{m}$-preparative) (Agilent). HPLC analytical conditions: mobile phase (MP) A: 50mM TEAB buffer (aq), mobile phase (MP) B: Acetonitrile/Methanol; flow rate $=1.0 \mathrm{ml} / \mathrm{min}$; UVVis detection: $\lambda 1=254 \mathrm{~nm}, \lambda 2=220 \mathrm{~nm}$. All final products were $\geq 95 \%$ purity as assessed by this method. Retention times (tR) and purity refer to UV detection at $220 \mathrm{~nm}$. Low-resolution mass spectra were acquired on an Advion Mass-express. 


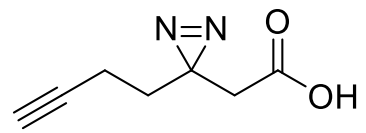

Minimalist linker acid

Synthesized according the literature procedure with minor modifications ${ }^{6}$.

To a stirred solution of 2-(3-But-3-ynyl-3H-diazirin-3-yl)-ethanol $(0.070 \mathrm{~g}, 0.51 \mathrm{mmol}, 1 \mathrm{eq}$.$) in acetone (6$ $\mathrm{mL}$ ) at $0^{\circ} \mathrm{C}$ Jones reagent ( $2 \mathrm{M} \mathrm{CrO}_{3}$ in $\mathrm{H}_{2} \mathrm{SO}_{4}(\mathrm{aq}), 1.0 \mathrm{~mL}, 2.0 \mathrm{mmol}, 4$ eq.) was added dropwise. The reaction solution was stirred at room temperature for $2 \mathrm{~h}$. After TLC showed the consumption of starting material, the reaction was quenched with isopropanol $(10 \mathrm{~mL})$ and the precipitate formed was separated. The filtrate was passed through celite and washed with acetone $(3 \times 10 \mathrm{~mL})$, dried over $\mathrm{MgSO}_{4}$, concentrated in vасио and redissolved in Ethyl acetate. It was then passed through a silica plug and then concentrated to give the photocrosslinker acid $(0.068 \mathrm{~g}, 89 \%)$ as a yellowish oil.

${ }^{1}$ H NMR (400 MHz, CDCl3) $\delta 11.91$ (s, 1H), 2.06 (dt, J = 7.3, 3.6 Hz, 2H), $2.03-1.98$ (m, 1H), 1.80 (t, $\mathrm{J}=7.3 \mathrm{~Hz}, 2 \mathrm{H})$.

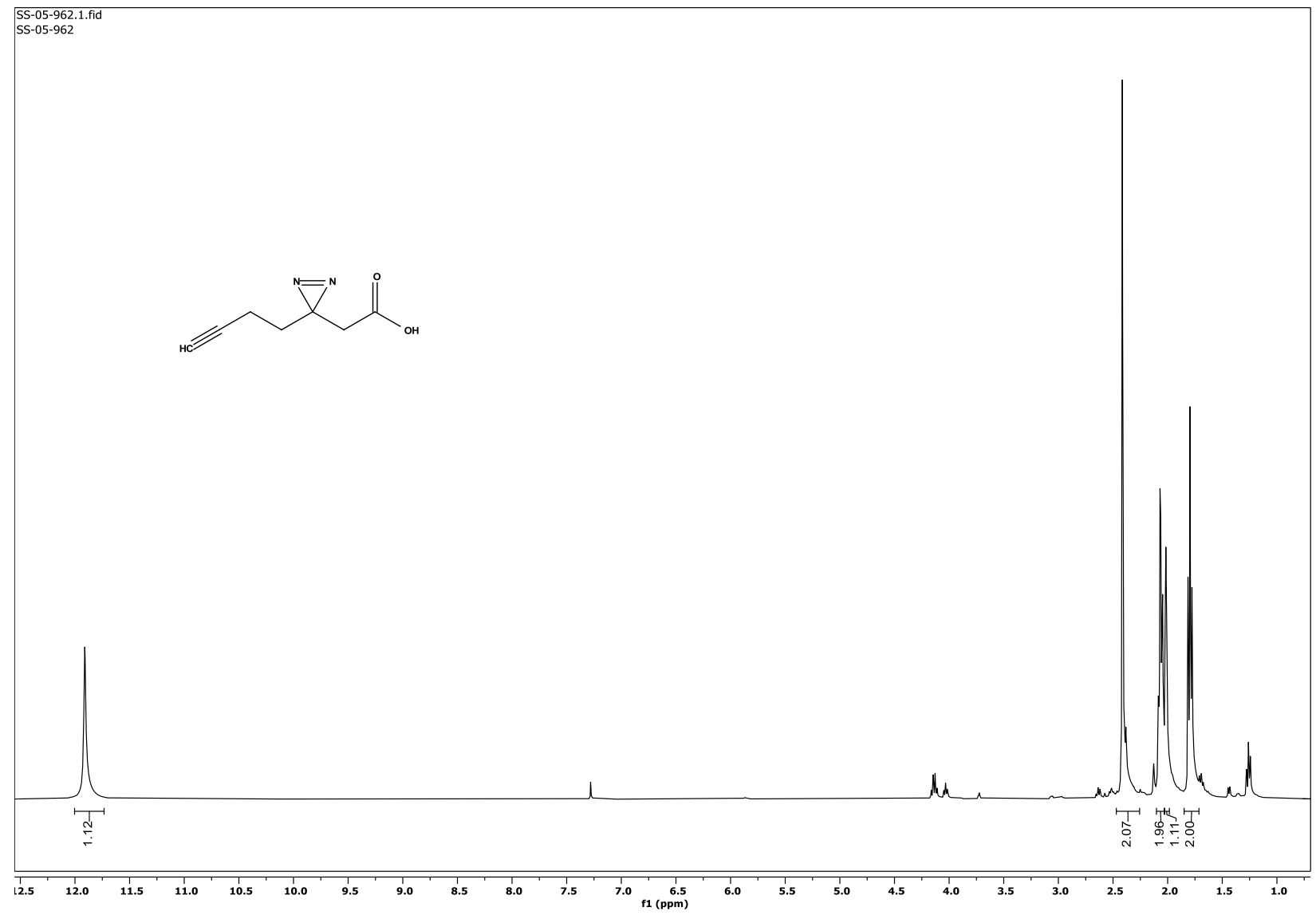




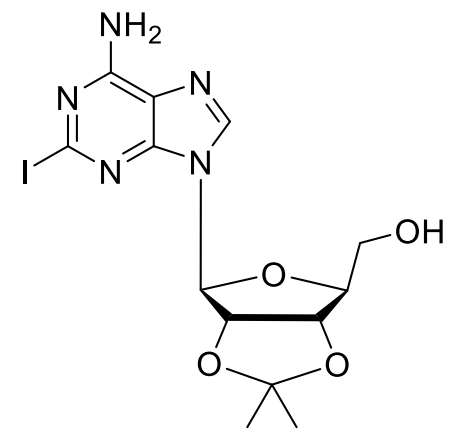

$2 \mathrm{~A}-1$

2-iodoadenosine $(0.906 \mathrm{~g}, 2.28 \mathrm{mmol})$ was suspended in acetone $(75 \mathrm{~mL})$ and cooled to $0^{\circ} \mathrm{C}$. $p$ - $\mathrm{TsOH}_{\mathrm{H}} \mathrm{H}_{2} \mathrm{O}$ ( $2.17 \mathrm{~g}, 11.44 \mathrm{mmol}, 5$ equiv.) was added and stirred the mixture at $\mathrm{rt}$ for $4 \mathrm{hrs}$. Upon completion of the reaction (monitored by TLC), it was quenched and neutralized with sat. $\mathrm{NaHCO}_{3}$ and extracted with ethyl acetate $(3 \times 50 \mathrm{~mL})$. The organic layer was passed through silica plug and dried over $\mathrm{MgSO}_{4}$. It was then concentrated and dried under high vacuum to yield an off white solid $(0.826 \mathrm{~g}, 83 \%)$.

${ }^{1}$ H NMR (400 MHz, DMSO) $\delta 8.28(\mathrm{~s}, 1 \mathrm{H}), 7.74(\mathrm{~s}, 2 \mathrm{H}), 6.05(\mathrm{~d}, J=2.7 \mathrm{~Hz}, 1 \mathrm{H}), 5.27(\mathrm{dd}, J=6.1,2.7$ $\mathrm{Hz}, 1 \mathrm{H}), 5.05(\mathrm{t}, J=5.4 \mathrm{~Hz}, 1 \mathrm{H}), 4.93(\mathrm{dd}, J=6.1,2.8 \mathrm{~Hz}, 1 \mathrm{H}), 4.19(\mathrm{q}, J=2.8,1.4,0.7 \mathrm{~Hz}, 1 \mathrm{H}), 3.54(\mathrm{td}$, $J=5.2,2.8 \mathrm{~Hz}, 2 \mathrm{H}), 1.54(\mathrm{~s}, 3 \mathrm{H}), 1.33(\mathrm{~s}, 3 \mathrm{H})$. LRMS (ESI) $\mathrm{m} / \mathrm{z}[\mathrm{M}]^{+}$calculated for $\mathrm{C}_{13} \mathrm{H}_{16} \mathrm{IN}_{5} \mathrm{O}_{4} 433.0$, observed 433.2.

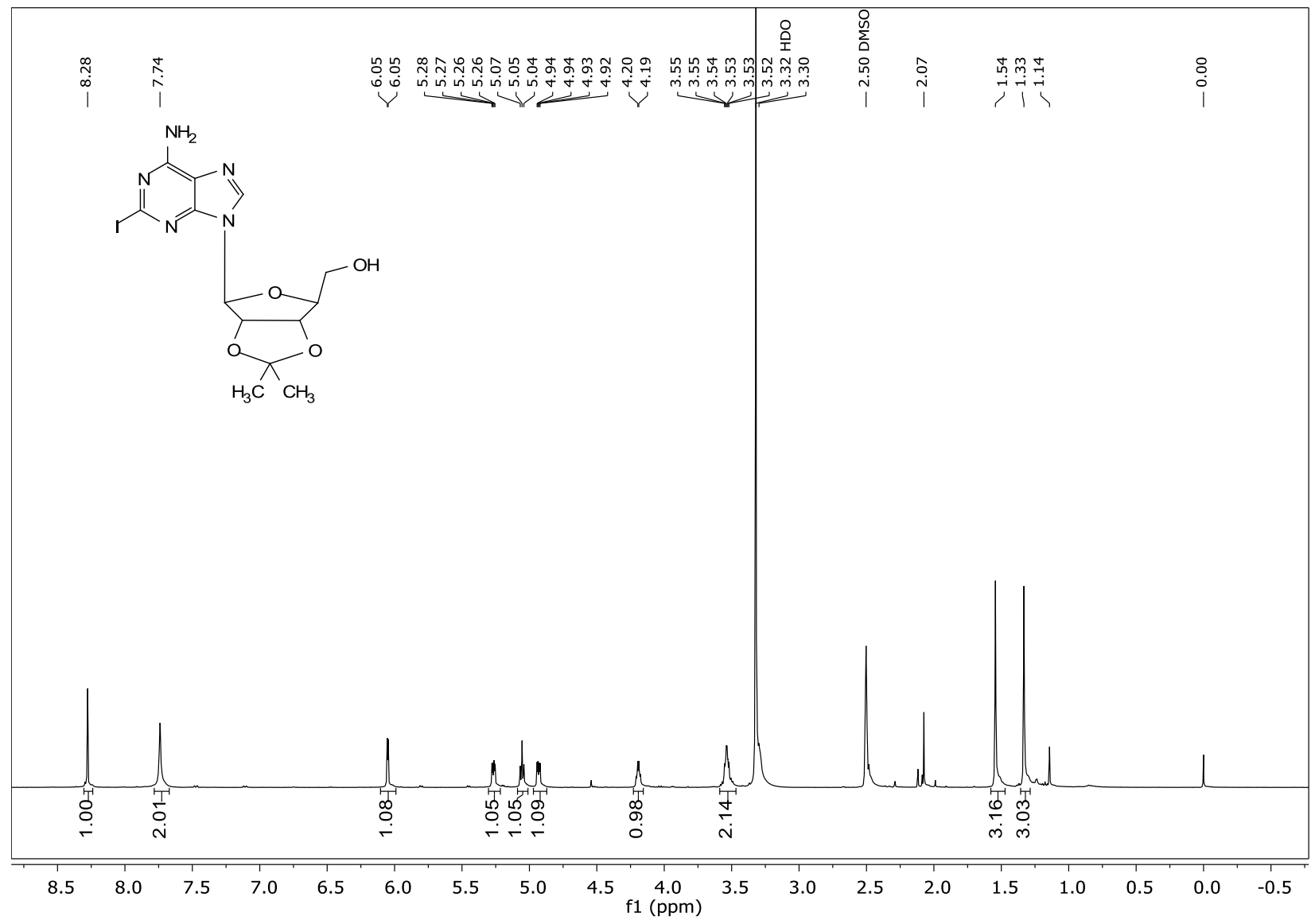




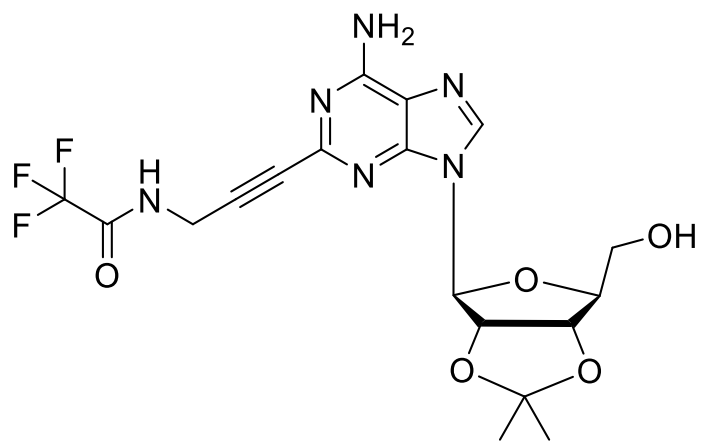

2A-2

To a solution of $2 \mathrm{~A}-1(0.264 \mathrm{~g}, 0.60 \mathrm{mmol})$ in anhydrous acetonitrile $(6.0 \mathrm{~mL})$ under Argon were added $\mathrm{Pd}\left(\mathrm{PPh}_{3}\right)_{2} \mathrm{Cl}_{2}(14 \mathrm{mg}, 0.012 \mathrm{mmol})$ and $\mathrm{CuI}(12 \mathrm{mg}, 0.024 \mathrm{mmol})$. The reaction flask was evacuated and refilled with argon three times, and stirred for 10 mins before adding Triethylamine $(6.0 \mathrm{~mL})$. N-propargyl trifluoroacetamide $(0.282 \mathrm{~g}, 1.8 \mathrm{mmol})$ was added after $10 \mathrm{mins}$ and stirred the mixture at room temperature for $5 \mathrm{~h}$. Upon completion of the reaction (monitored by TLC), the mixture was concentrated and the crude residue was purified via a Combiflash Companion system (EtOAc/MeOH). Fractions containing the desired product were collected and concentrated in vacuo to yield the product as an amorphous pale yellow solid $(0.18 \mathrm{~g}, 67 \%)$.

${ }^{1} \mathbf{H}$ NMR (400 MHz, CDCl 3$) \delta 7.89(\mathrm{~s}, 1 \mathrm{H}), 6.07(\mathrm{~d}, J=10.3 \mathrm{~Hz}, 1 \mathrm{H}), 5.91(\mathrm{~s}, 1 \mathrm{H}), 5.83(\mathrm{~d}, J=4.9 \mathrm{~Hz}$, 1H), 5.24 (s, 1H), $5.23-5.16(\mathrm{~m}, 2 \mathrm{H}), 5.14(\mathrm{~d}, J=6.0 \mathrm{~Hz}, 1 \mathrm{H}), 4.53(\mathrm{~s}, 1 \mathrm{H}), 4.18(\mathrm{~d}, J=4.4 \mathrm{~Hz}, 2 \mathrm{H}), 4.00$ $(\mathrm{d}, J=12.7 \mathrm{~Hz}, 1 \mathrm{H}), 3.80(\mathrm{t}, J=11.1 \mathrm{~Hz}, 1 \mathrm{H}), 3.49$ (s, 1H), $1.64(\mathrm{~s}, 3 \mathrm{H}), 1.38$ (s, 3H). LR-MS (ESI) m/z $[\mathrm{M}]^{+}$calculated for $\mathrm{C}_{18} \mathrm{H}_{19} \mathrm{~F}_{3} \mathrm{~N}_{6} \mathrm{O}_{5} 456.1$, observed 457.0

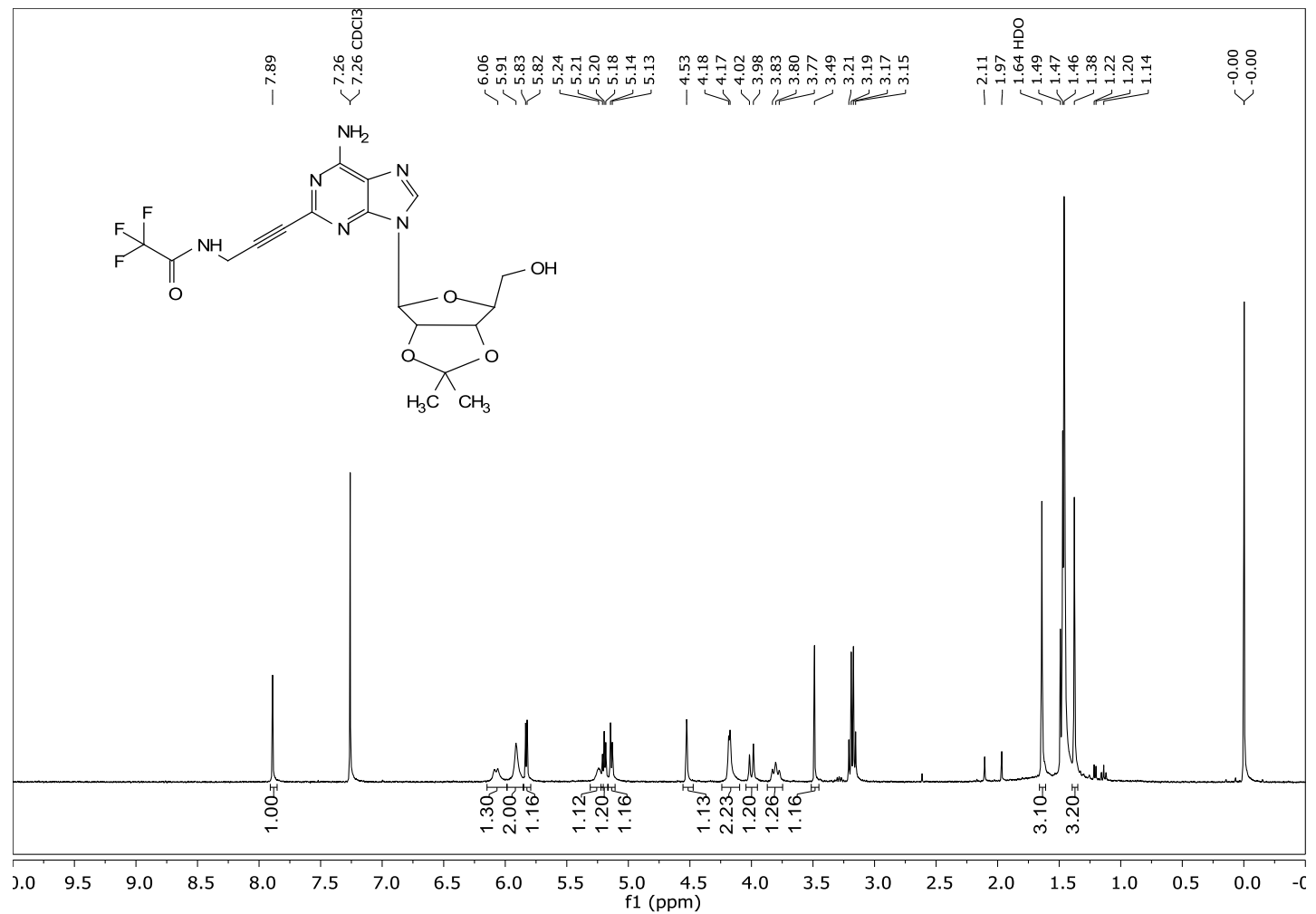




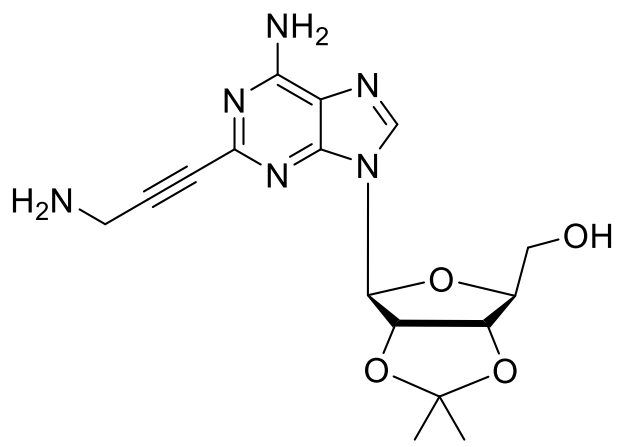

2A-3

2A-2 (0.17 g, $0.37 \mathrm{mmol})$ was dissolved in $\mathrm{MeOH}(2.0 \mathrm{~mL})$ and added aqueous $\mathrm{NH}_{4} \mathrm{OH}(8.0 \mathrm{~mL})$. Stirred the mixture at room temperature $2.5 \mathrm{hrs}$. Upon completion of the reaction (monitored by TLC), all the solvents were evaporated and further co-evaporated with acetonitrile to yield the product as off-white solid (quantitative yield).

${ }^{1}$ H NMR (400 MHz, MeOD) $\delta 8.37$ (s, 1H), $6.13(\mathrm{~s}, 1 \mathrm{H}), 5.22(\mathrm{~s}, 1 \mathrm{H}), 5.05$ (s, 1H), 4.40 (s, 1H), 4.02 (s, $1 \mathrm{H}), 3.88-3.69(\mathrm{~m}, 2 \mathrm{H}), 1.62(\mathrm{~s}, 3 \mathrm{H}), 1.38(\mathrm{~s}, 3 \mathrm{H})$. Missing peaks due to overlapping peaks with $\mathrm{H}_{2} \mathrm{O}$. ). LR-MS (ESI) m/z [M] calculated for $\mathrm{C}_{16} \mathrm{H}_{20} \mathrm{~N}_{6} \mathrm{O}_{4} 360.2$, observed 360.8 .

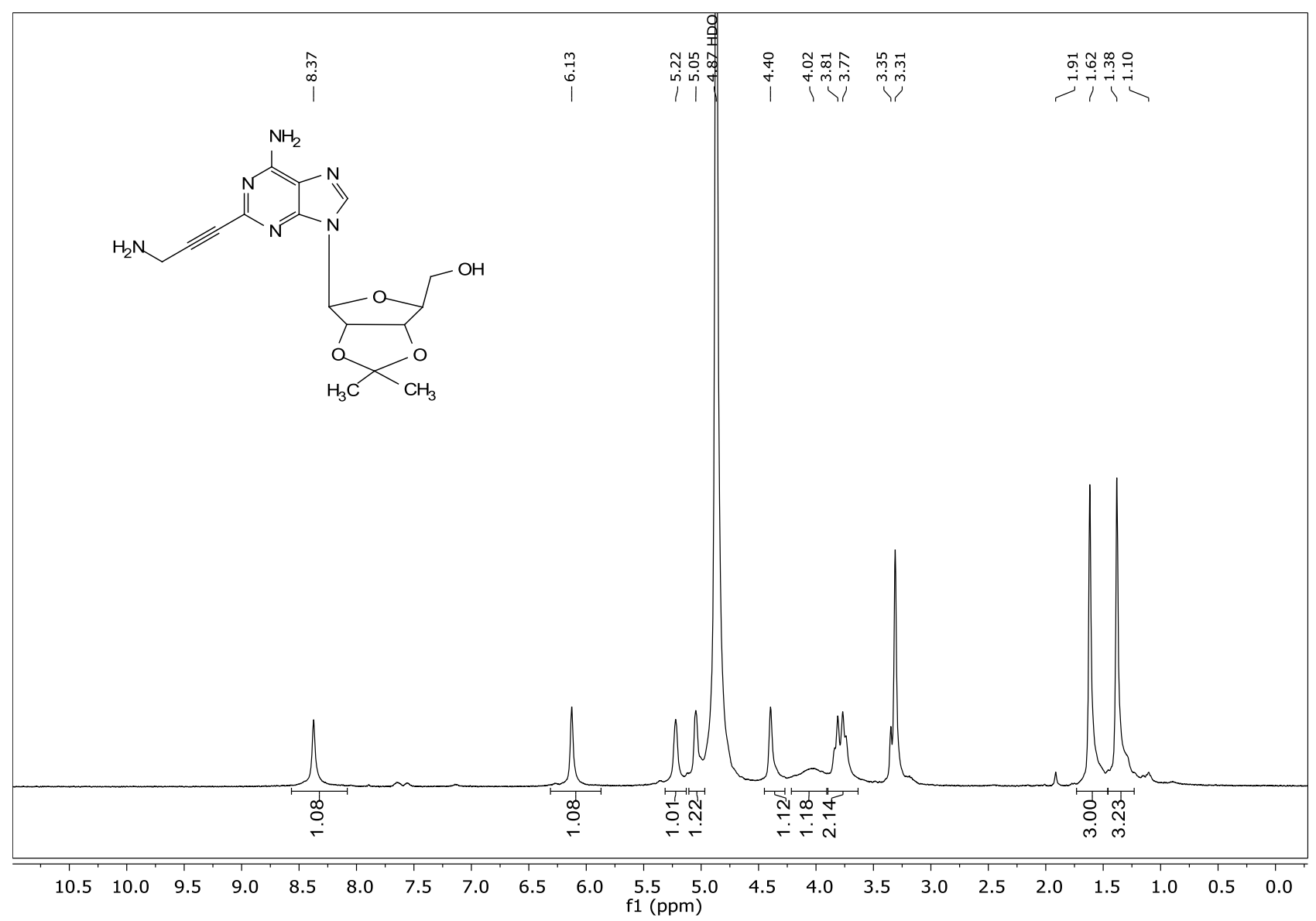




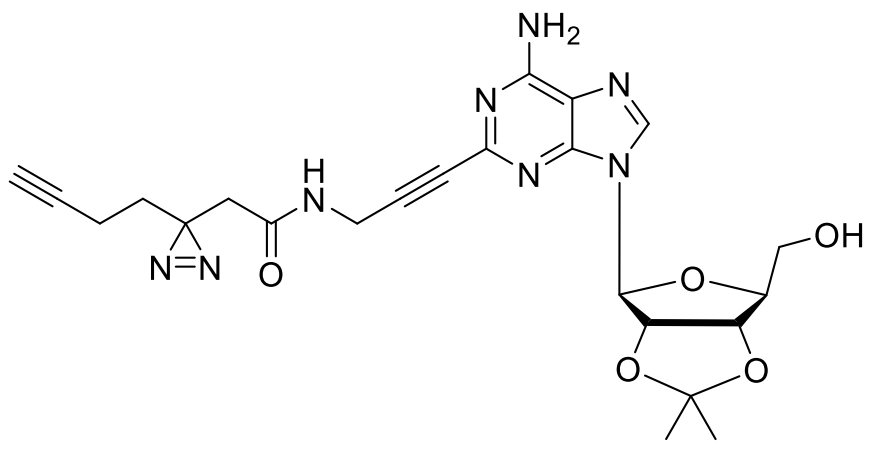

\section{$2 A-4$}

Amine 2A-3 (0.136 g, $0.37 \mathrm{mmol}$ ) and 2-(3-(but-3-yn-1-yl)-3H-diazirin-3-yl)acetic acid (0.069 g, 0.45 mmol, 1.2 equiv.) were dissolved in anhydrous DMF $(2.7 \mathrm{~mL})$ and cooled to $0^{\circ} \mathrm{C}$. DIPEA $0.13 \mathrm{~mL}, 2.0$ equiv.) and stirred for $5 \mathrm{~min}$, followed by addition of Propyl-phosphonic andydride (T3P) (0.34 mL, 0.56 $\mathrm{mmol}$ ). The mixture was stirred for $30 \mathrm{~min}$ at $0^{\circ} \mathrm{C}$. Upon completion of the reaction (monitored by TLC), it was dissolved in ethyl acetate $(5 \mathrm{~mL})$ and added with $5 \% \mathrm{NaHCO}_{3}(5 \mathrm{~mL})$. The layers were separated and extracted the aqueous layer with ethyl acetate. It was then washed with brine $(5 \mathrm{~mL})$ and passed through a silica plug and dried over $\mathrm{MgSO}_{4}$. The solvent was evaporated and dried under high vacuum to yield the product as an off-white solid $(0.128 \mathrm{~g}, 69 \%)$.

${ }^{1}$ H NMR (400 MHz, CDCl $) \delta 8.01(\mathrm{~s}, 1 \mathrm{H}), 7.28(\mathrm{~s}, 1 \mathrm{H}), 6.61(\mathrm{~s}, 2 \mathrm{H}), 6.39(\mathrm{~s}, 1 \mathrm{H}), 5.85(\mathrm{~d}, J=4.7 \mathrm{~Hz}$, $1 \mathrm{H}), 5.29-5.10(\mathrm{~m}, 2 \mathrm{H}), 4.51(\mathrm{~s}, 1 \mathrm{H}), 4.30-4.26(\mathrm{~m}, 2 \mathrm{H}), 4.04-3.93(\mathrm{~d}, J=12.7 \mathrm{~Hz} 1 \mathrm{H}), 3.79(\mathrm{~s}, 1 \mathrm{H})$, 2.29 (s, 2H), $2.13-1.93(\mathrm{~m}, 3 \mathrm{H}), 1.85-1.77$ (m, 2H), 1.63 (s, 3H), 1.37 (s, 3H). LR-MS (ESI) m/z [M] calculated for $\mathrm{C}_{23} \mathrm{H}_{26} \mathrm{~N}_{8} \mathrm{O}_{5} 494.2$, observed 494.7 .

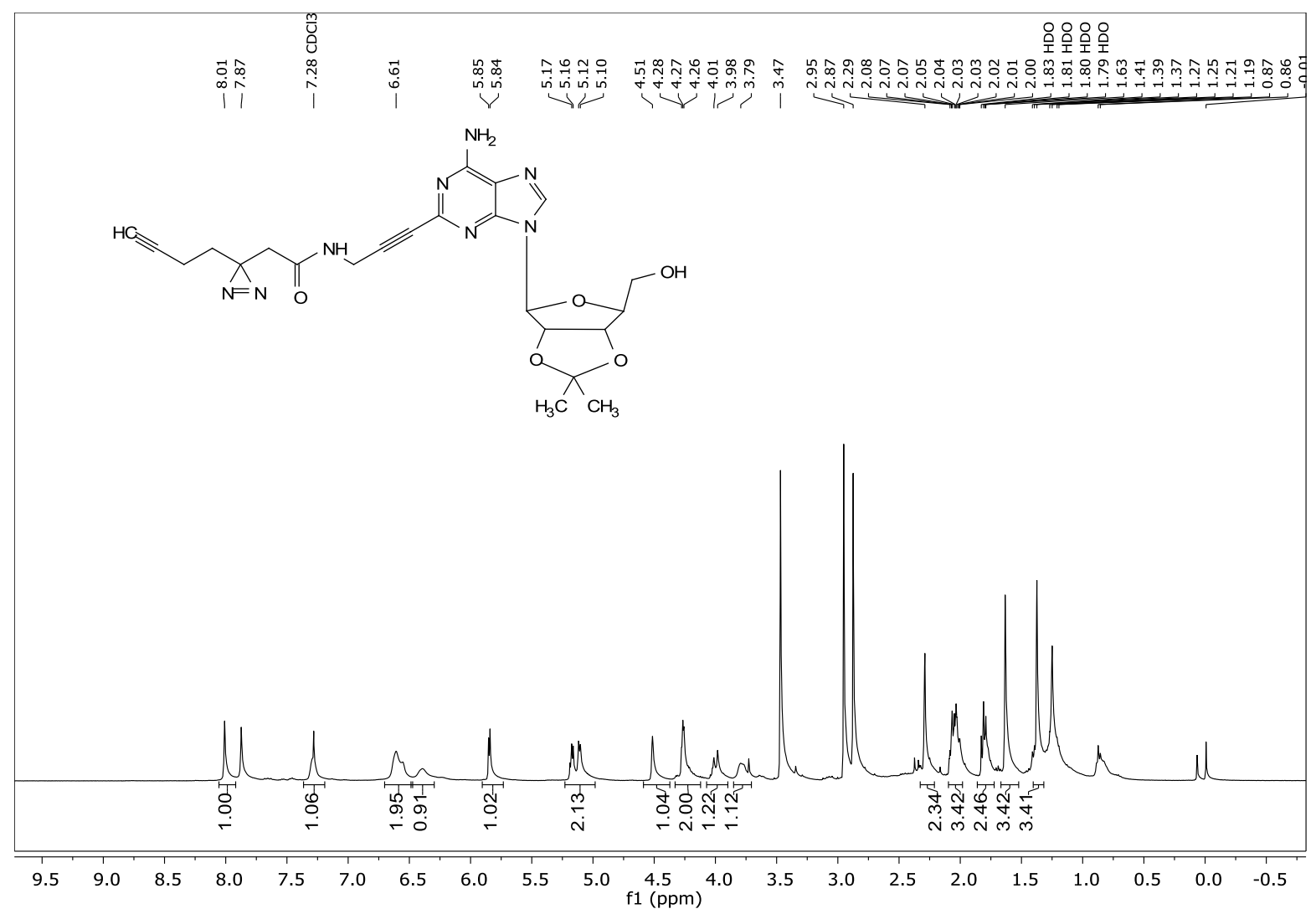




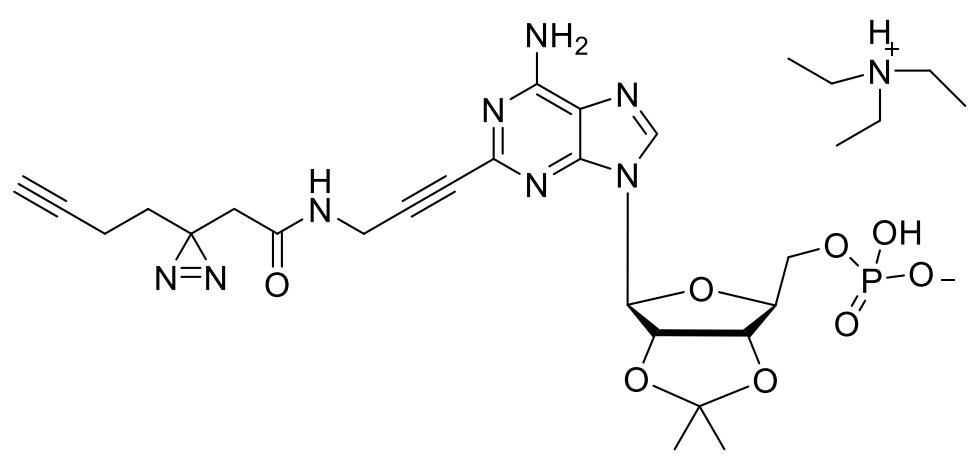

2A-5

A solution of $2 \mathrm{~A}-4(0.128 \mathrm{~g}, 0.26 \mathrm{mmol})$ dissolved in THF $(2.6 \mathrm{~mL})$ under argon was cooled to $0{ }^{\circ} \mathrm{C}$ and added triethylamine $\left(0.36 \mathrm{~mL}, 2.6 \mathrm{mmol}, 10\right.$ equiv.). After stirring for $10 \mathrm{mins}, \mathrm{POCl}_{3}(50 \mu \mathrm{L}, 0.51 \mathrm{mmol}$, 2 equiv.) was added dropwise solution turned cloudy. After 15 mins TLC showed the consumption of starting material. Immediately quenched the reaction with water $(1.0 \mathrm{~mL})$ and evaporated the solvents and co-evaporated with acetonitrile to yield a solid. Dissolved the solid in minimum amount of methanol and subjected to C-18 column chromatography using $50 \mathrm{mM}$ TEAB buffer and methanol as the solvent system. The fractions containing the product were pooled together and evaporated the solvent to yield the desired compound 2A-5 (90 mg, 50\%).

${ }^{1}$ H NMR (400 MHz, DMSO) $\delta 8.80(\mathrm{t}, J=5.1 \mathrm{~Hz}, 1 \mathrm{H}), 8.49(\mathrm{~s}, 1 \mathrm{H}), 7.47(\mathrm{~s}, 2 \mathrm{H}), 6.09(\mathrm{~d}, J=2.7 \mathrm{~Hz}, 1 \mathrm{H})$, $5.27(\mathrm{dd}, J=5.9,2.9 \mathrm{~Hz}, 1 \mathrm{H}), 5.02(\mathrm{~d}, J=6.0 \mathrm{~Hz}, 1 \mathrm{H}), 4.33(\mathrm{~s}, 2 \mathrm{H}), 4.10(\mathrm{~d}, J=5.1 \mathrm{~Hz}, 2 \mathrm{H}), 3.89-3.73$ $(\mathrm{m}, 2 \mathrm{H}), 2.80(\mathrm{t}, J=2.6 \mathrm{~Hz}, 1 \mathrm{H}), 2.31(\mathrm{~s}, 2 \mathrm{H}), 2.10-1.96(\mathrm{~m}, 2 \mathrm{H}), 1.68(\mathrm{t}, J=7.5 \mathrm{~Hz}, 2 \mathrm{H}), 1.53(\mathrm{~s}, 3 \mathrm{H})$, $1.31(\mathrm{~s}, 3 \mathrm{H})$. LR-MS (ESI) m/z [M] calculated for $\mathrm{C}_{23} \mathrm{H}_{27} \mathrm{~N}_{8} \mathrm{O}_{8} \mathrm{P}$ 574.2, observed 574.8. 


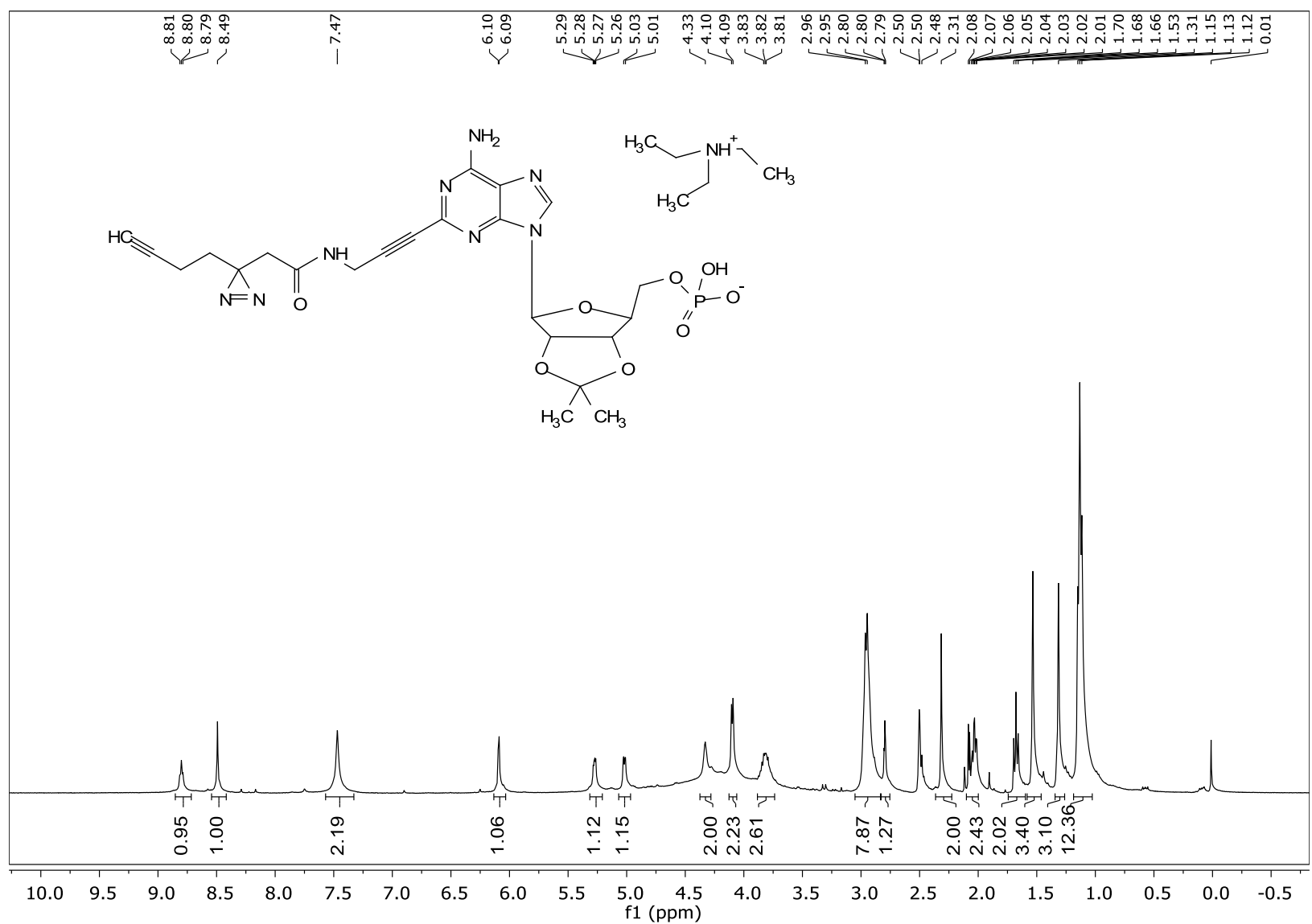




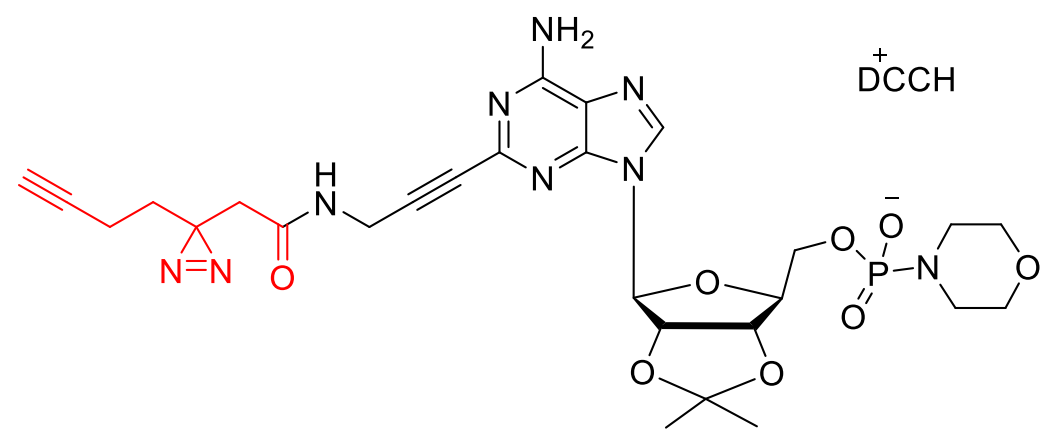

$2 \mathrm{~A}-6$

2A-5 (90 mg, $0.13 \mathrm{mmol})$ was dissolved in t-BuOH $(7.0 \mathrm{~mL})$, followed by dropwise addition of morpholine (60 $\mu \mathrm{L}, 5.0$ equiv). The reaction mixture was first stirred at RT for $15 \mathrm{~min}$ and then refluxed. Dicyclohexylcarbodiimide (DCC, $0.11 \mathrm{~g}, 4.0$ equiv) was dissolved in t-BuOH (3.5 mL) and divided into 10 aliquots. An aliquot was added dropwise to the reaction mixture under reflux every ten minutes. After 2 h, DCC addition was complete and reflux was continued for another $5 \mathrm{~min}$. After reaction was completed, (as determined by MS analysis) the mixture was cooled and concentrated under vacuum. Addition of ether formed a precipitate, then the ether was decanted and fresh ether was added to wash the precipitate. The precipitate was dried under high vacuum to form $2 \mathrm{~A}-6$ as an off-white powder $(0.116 \mathrm{~g}, 96 \%)$.

${ }^{1}$ H NMR (400 MHz, D $\left.\mathbf{O}\right) \delta 8.31(\mathrm{~s}, 1 \mathrm{H}), 6.18(\mathrm{~s}, 1 \mathrm{H}), 5.42(\mathrm{~d}, \mathrm{~J}=6.1 \mathrm{~Hz}, 1 \mathrm{H}), 5.13(\mathrm{~d}, \mathrm{~J}=6.1 \mathrm{~Hz}, 1 \mathrm{H})$, $4.16(\mathrm{~s}, 2 \mathrm{H}), 3.94-3.83(\mathrm{~m}, 4 \mathrm{H}), 3.72(\mathrm{~s}, 2 \mathrm{H}), 3.35(\mathrm{~d}, \mathrm{~J}=4.2 \mathrm{~Hz}, 5 \mathrm{H}), 3.28-3.15(\mathrm{~m}, 4 \mathrm{H}), 2.62(\mathrm{~d}, \mathrm{~J}=$ $4.6 \mathrm{~Hz}, 3 \mathrm{H}), 2.41(\mathrm{~s}, 2 \mathrm{H}), 2.29(\mathrm{~d}, \mathrm{~J}=2.6 \mathrm{~Hz}, 1 \mathrm{H}), 2.02(\mathrm{dt}, \mathrm{J}=7.1,3.5 \mathrm{~Hz}, 2 \mathrm{H}), 1.71(\mathrm{t}, \mathrm{J}=7.2 \mathrm{~Hz}, 2 \mathrm{H})$, $1.60(\mathrm{~s}, 3 \mathrm{H}), 1.40(\mathrm{~s}, 3 \mathrm{H})$. LR-MS (ESI) m/z [M] calculated for $\mathrm{C}_{27} \mathrm{H}_{34} \mathrm{~N}_{9} \mathrm{O}_{8} \mathrm{P}$ 643.2, observed 643.7. 


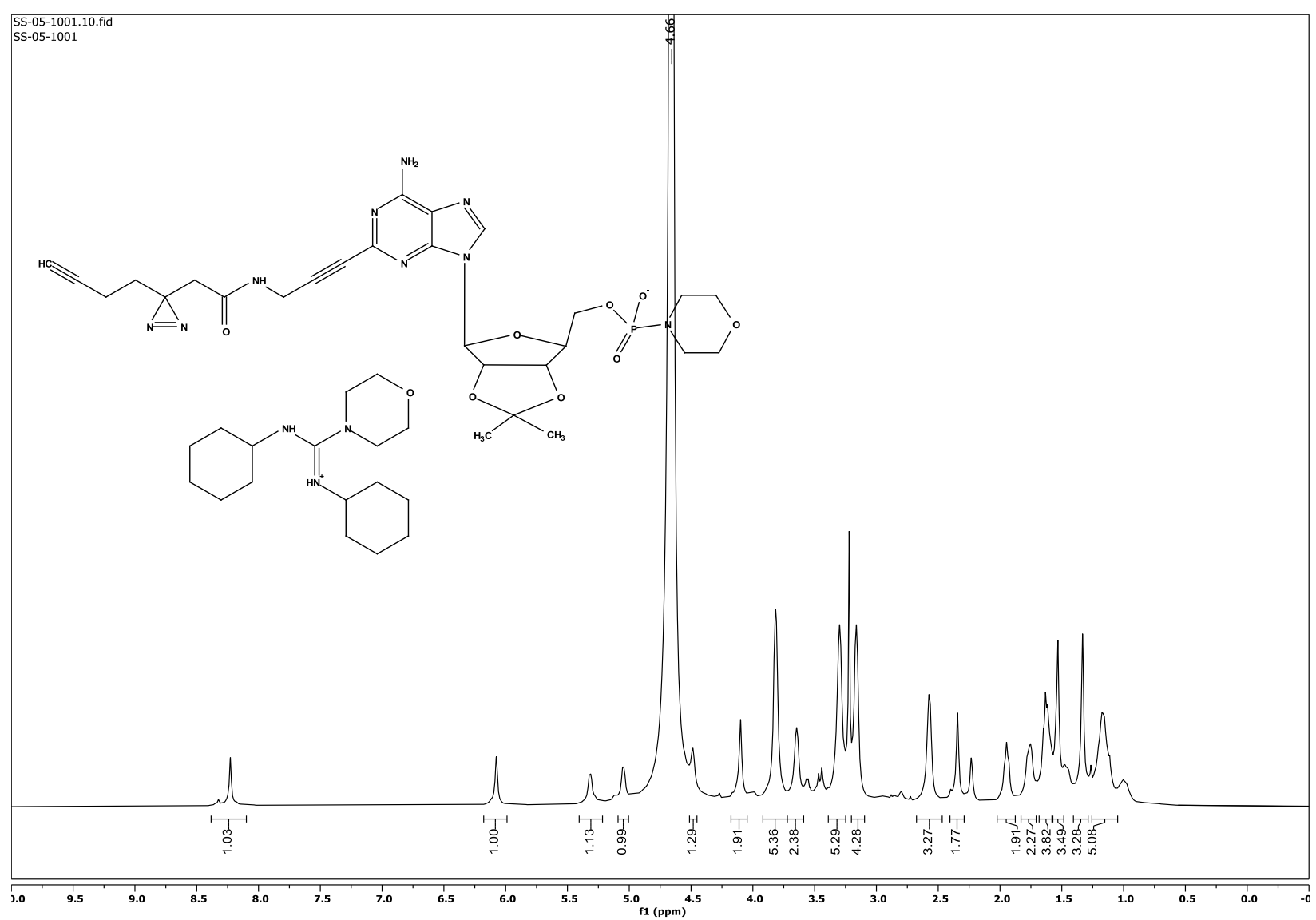




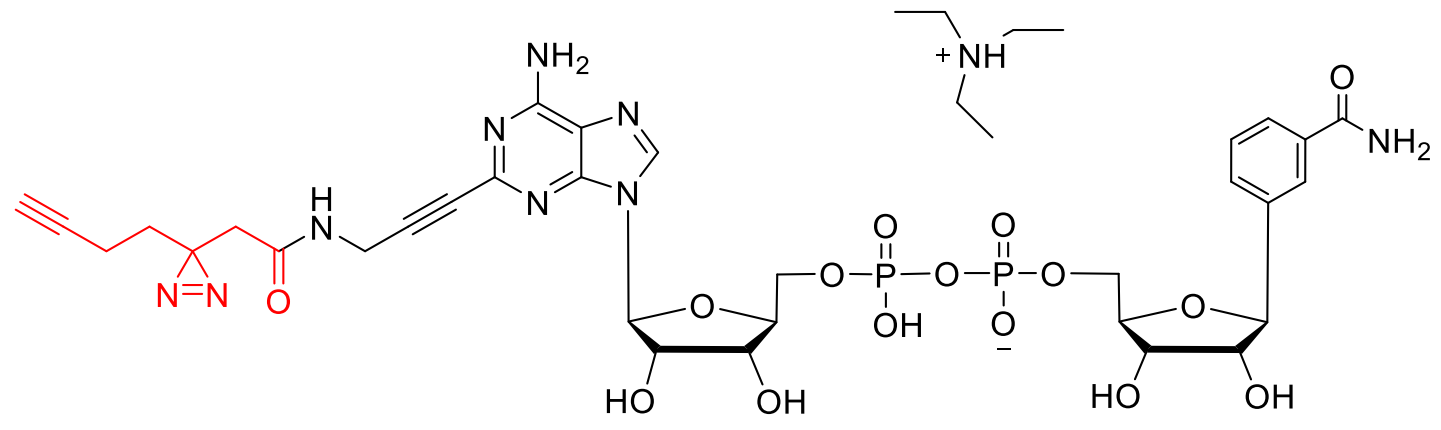

2-ad-BAD

2-diaziridylalkyne AMP-morpholidate 2A-6 (47 mg, $0.05 \mathrm{mmol}), \mathbf{B} 4$ (92 mg, $0.11 \mathrm{mmol}, 2.1 \mathrm{equiv}$ ), and $\mathrm{MgSO}_{4}\left(13 \mathrm{mg}, 0.1 \mathrm{mmol}, 2.0\right.$ equiv) were dissolved in a solution of $\mathrm{MnCl}_{2}(0.5 \mathrm{ml}, 0.2 \mathrm{M}$ in formamide) and stirred at room temperature for overnight. After the completion of the coupling reaction monitored by MS, $\mathrm{H}_{2} \mathrm{O}(4.0 \mathrm{~mL})$ was added. To this mixture) was added DOWEX 50x (1.0 g) and the mixture was stirred overnight at RT. After the complete deprotection of acetonide groups (monitored by MS), the resin was filtered off and the aqueous solution was concentrated to dryness. Methanol $(5 \mathrm{~mL})$ was added to form a cloudy suspension and the reaction was centrifuged to separate the precipitate. The methanol layer was then evaporated to dryness and the resultant solid was further washed with acetone $(4.0 \mathrm{~mL})$ and decanted. The solid was again resuspended in methanol and the crude product was purified via preparative HPLC using $50 \mathrm{mM}$ TEAB buffer and acetonitrile. The fraction containing the product were pooled and concentrated to yield the product as TEA salt $(4.2 \mathrm{mg})$.

${ }^{1}$ H NMR (400 MHz, MeOD) $\delta 8.60(\mathrm{~s}, 1 \mathrm{H}), 8.07(\mathrm{~s}, 1 \mathrm{H}), 7.80(\mathrm{~d}, \mathrm{~J}=8.0 \mathrm{~Hz}, 1 \mathrm{H}), 7.58(\mathrm{~d}, \mathrm{~J}=7.5 \mathrm{~Hz}, 1 \mathrm{H})$, $7.41(\mathrm{t}, \mathrm{J}=7.7 \mathrm{~Hz}, 1 \mathrm{H}), 6.04(\mathrm{~d}, \mathrm{~J}=4.9 \mathrm{~Hz}, 1 \mathrm{H}), 4.56(\mathrm{t}, \mathrm{J}=4.7 \mathrm{~Hz}, 1 \mathrm{H}), 4.49(\mathrm{t}, \mathrm{J}=4.8 \mathrm{~Hz}, 1 \mathrm{H}), 4.30(\mathrm{~m}$, $3 \mathrm{H}), 4.16(\mathrm{~s}, 1 \mathrm{H}), 4.03-3.96(\mathrm{~m}, 1 \mathrm{H}), 2.36(\mathrm{~s}, 2 \mathrm{H}), 2.29(\mathrm{t}, \mathrm{J}=2.7 \mathrm{~Hz}, 1 \mathrm{H}), 2.09(\mathrm{td}, \mathrm{J}=7.4,2.6 \mathrm{~Hz}, 2 \mathrm{H})$, $1.76(\mathrm{t}, \mathrm{J}=7.5 \mathrm{~Hz}, 2 \mathrm{H})$. LR-MS (ESI) $\mathrm{m} / \mathrm{z}[\mathrm{M}]^{+}$calculated for $\mathrm{C}_{32} \mathrm{H}_{37} \mathrm{~N}_{9} \mathrm{O}_{15} \mathrm{P}_{2}$ 849.2, observed 849.4. 


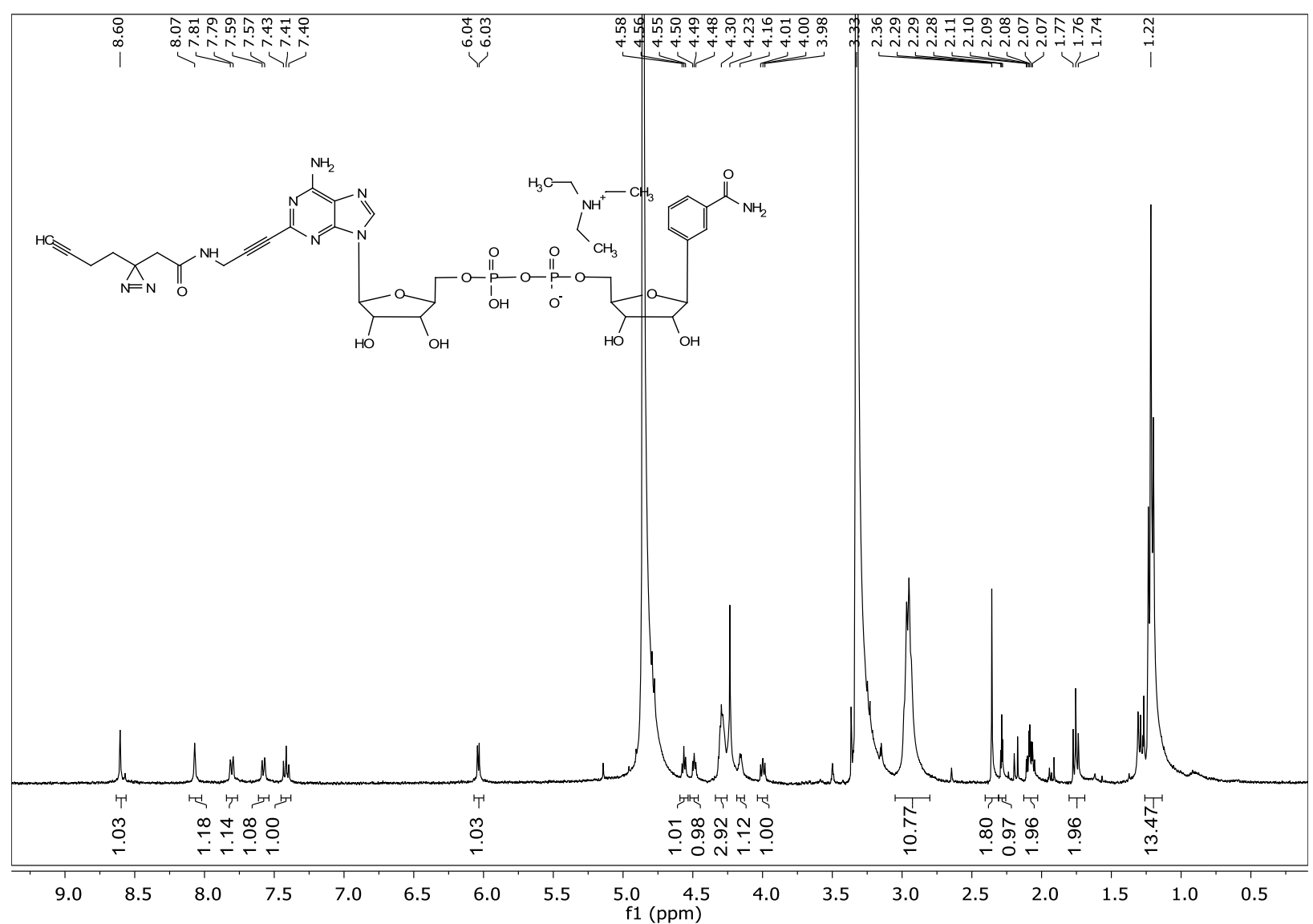




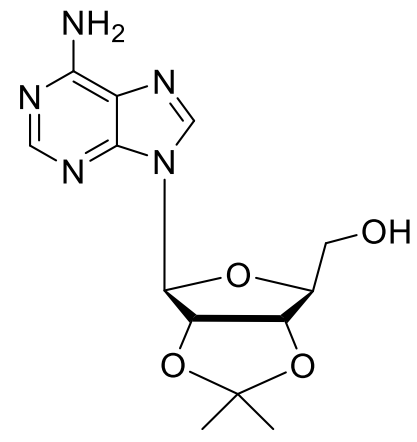

6A-1

To a solution of adenosine $(6.68 \mathrm{~g}, 25.0 \mathrm{mmol})$ in $500 \mathrm{~mL}$ of acetone was treated with perchloroic acid (3.0 $\mathrm{mL}, 70 \%$ in water) at $0{ }^{\circ} \mathrm{C}$ then stirred at room temperature for $2 \mathrm{~h}$. The resulting solution was neutralized with $\mathrm{Na}_{2} \mathrm{CO}_{3}$ at $0{ }^{\circ} \mathrm{C}$ and the resulting white solid removed by filtration. The filtrate was concentrated under reduced pressure to yield acetonide $(4.67 \mathrm{~g}, 95 \%)$.

${ }^{1}$ H NMR (400 MHz, DMSO) $\delta 8.25(\mathrm{~s}, 1 \mathrm{H}), 8.07(\mathrm{~s}, 1 \mathrm{H}), 6.03(\mathrm{~d}, J=3.0 \mathrm{~Hz}, 1 \mathrm{H}), 5.25(\mathrm{dd}, J=6.1,3.1$ $\mathrm{Hz}, 2 \mathrm{H}), 5.16(\mathrm{~s}, 1 \mathrm{H}), 4.87(\mathrm{dd}, J=6.1,2.4 \mathrm{~Hz}, 2 \mathrm{H}), 4.12(\mathrm{q}, J=4.6 \mathrm{~Hz}, 2 \mathrm{H}), 3.45$ (qd, $J=11.7,4.8 \mathrm{~Hz}$, $3 \mathrm{H}), 1.45(\mathrm{~s}, 3 \mathrm{H}), 1.23(\mathrm{~s}, 3 \mathrm{H})$.

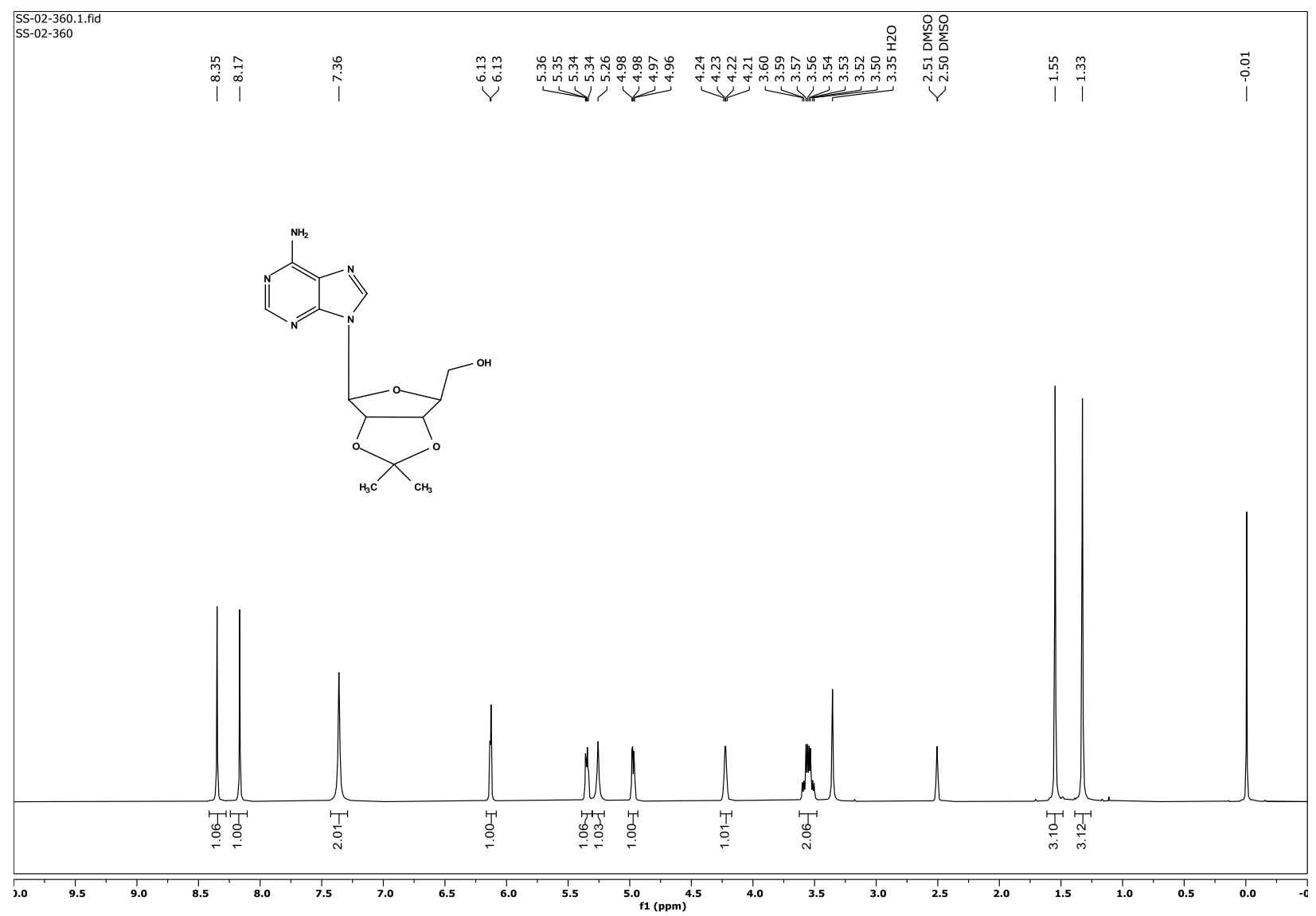




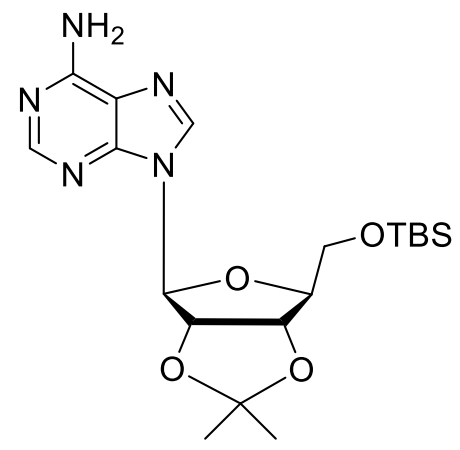

6A-2

To a solution $6 \mathrm{~A}-1(1.84 \mathrm{~g}, 6.0 \mathrm{mmol})$ in $6 \mathrm{~mL}$ of DMF and imidazole $(1.02 \mathrm{~g}, 5 \mathrm{mmol})$ at $0{ }^{\circ} \mathrm{C}$ was added t-butyldimethylsilyl chloride $(1.18 \mathrm{~g}, 7.8 \mathrm{mmol})$ under $\mathrm{N}_{2}$ atmosphere. The reaction mixture was stirred at room temperature for overnight and quenched with water. Extracted with the aqueous mixture with DCM $(50 \mathrm{ml}$ x 3$)$ and dried over $\mathrm{MgSO}_{4}$. Evaporated all the solvent to yield pure product $(2.39 \mathrm{~g}, 95 \%)$.

${ }^{1}$ H NMR (400 MHz, CDCl $) \delta 8.37(\mathrm{~s}, 1 \mathrm{H}), 8.12(\mathrm{~s}, 1 \mathrm{H}), 6.25(\mathrm{~s}, 2 \mathrm{H}), 6.16(\mathrm{~d}, J=2.4 \mathrm{~Hz}, 1 \mathrm{H}), 5.21(\mathrm{dd}$, $J=6.1,2.4 \mathrm{~Hz}, 1 \mathrm{H}), 4.92(\mathrm{dd}, J=6.1,2.3 \mathrm{~Hz}, 1 \mathrm{H}), 3.88(\mathrm{dd}, J=11.3,3.6 \mathrm{~Hz}, 1 \mathrm{H}), 3.76(\mathrm{dd}, J=11.3,3.9$ $\mathrm{Hz}, 1 \mathrm{H}), 1.62(\mathrm{~s}, 3 \mathrm{H}), 1.39$ (s, 3H), $0.82(\mathrm{~s}, 9 \mathrm{H}),-0.02(\mathrm{~d}, J=0.9 \mathrm{~Hz}, 6 \mathrm{H})$.

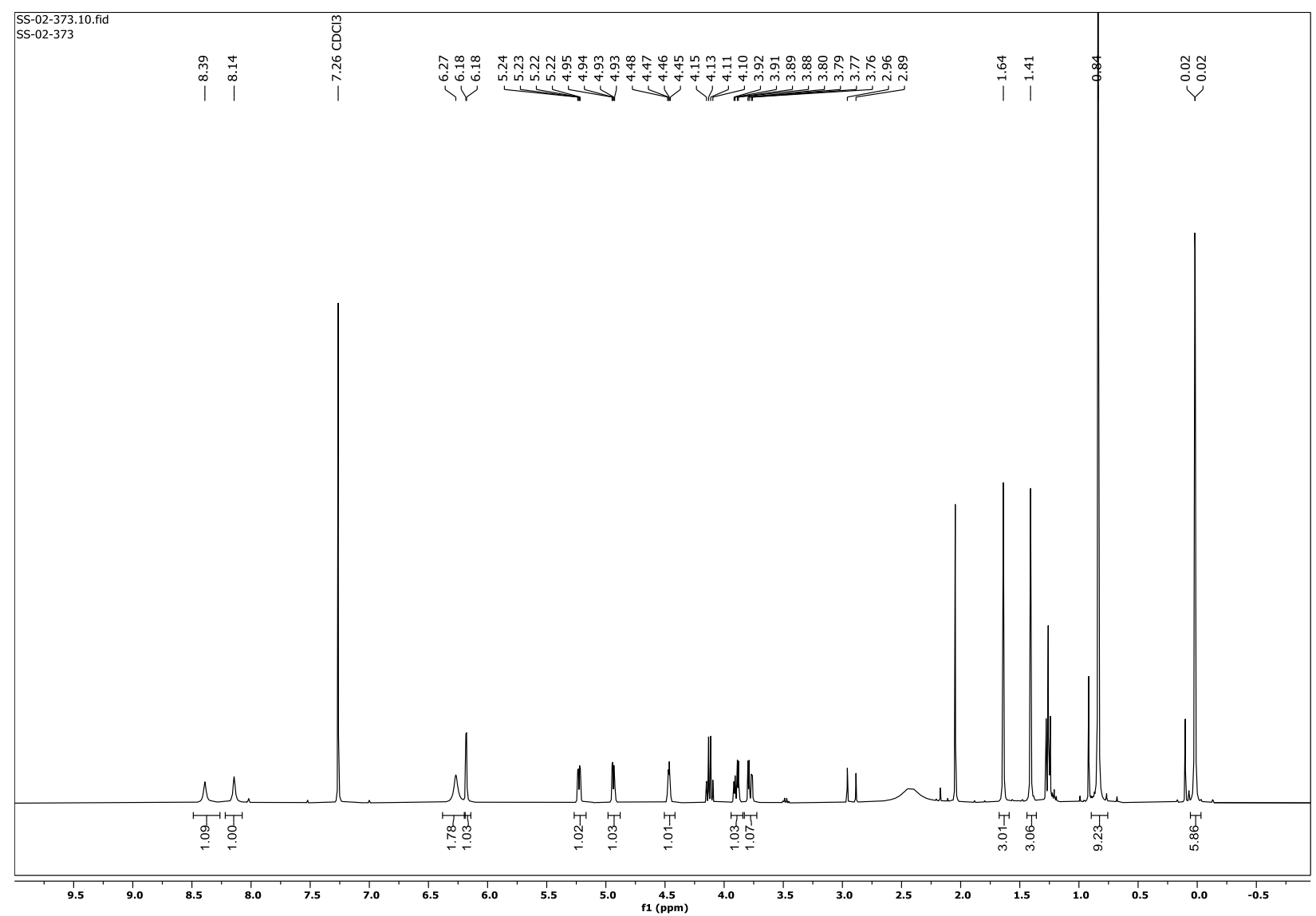




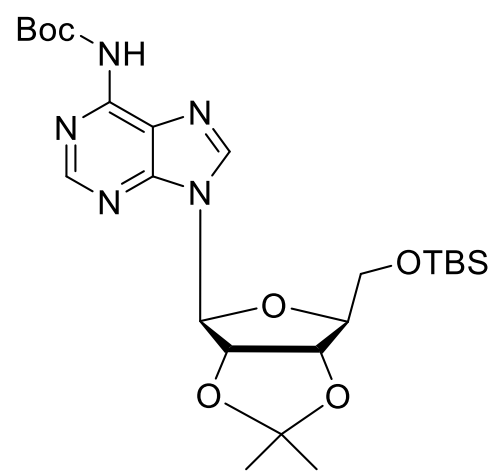

6A-3

To a solution of 6A-2 $(0.61 \mathrm{~g}, 1.46 \mathrm{mmol})$ in dry THF $(8.0 \mathrm{ml})$ was added Di-tert-butyl dicarbonate $(0.96$ $\mathrm{g}, 4.38 \mathrm{mmol}, 3.0$ equiv.) and DMAP $(0.036 \mathrm{~g}, 0.29 \mathrm{mmol}, 0.2$ equiv.). The mixture was stirred at room temperature for $4 \mathrm{~h}$. After the reaction was completed monitored by TLC. It was then quenched with water and extracted Ethyl acetate $\left(50 \mathrm{~mL}\right.$ x 3) and dried over $\mathrm{MgSO}_{4}$ and concentrated. The crude was then dissolved in dry $\mathrm{MeCN}$ and treated with $\mathrm{LiBr}(0.38 \mathrm{~g}, 4.38 \mathrm{mmol}, 3$ equiv.). The mixture was stirred at 65 ${ }^{\circ} \mathrm{C}$ for $8 \mathrm{hrs}$. Evaporated and the solvent and the crude residue was purified via a Combiflash Companion system (EtOAc/Hexanes) to isolate the product as off white crystalline solid ( $0.36 \mathrm{~g}, 47 \%$ in 2 steps).

${ }^{1} \mathbf{H}$ NMR (400 MHz, CDCl$) \delta 8.81(\mathrm{~s}, 1 \mathrm{H}), 8.27(\mathrm{~s}, 1 \mathrm{H}), 6.22(\mathrm{~d}, J=2.4 \mathrm{~Hz}, 1 \mathrm{H}), 5.26(\mathrm{dd}, J=6.1,2.4 \mathrm{~Hz}, 1 \mathrm{H})$, $4.93(\mathrm{dd}, J=6.1,2.2 \mathrm{~Hz}, 1 \mathrm{H}), 4.49(\mathrm{q}, J=3.4 \mathrm{~Hz}, 1 \mathrm{H}), 3.90(\mathrm{dd}, J=11.3,3.4 \mathrm{~Hz}, 1 \mathrm{H}), 3.78(\mathrm{dd}, J=11.3,3.8 \mathrm{~Hz}$, $1 \mathrm{H}), 1.64$ (s, 3H), 1.57 (s, 9H), $1.41(\mathrm{~s}, 3 \mathrm{H}), 0.82(\mathrm{~s}, 9 \mathrm{H}), 0.00(\mathrm{~s}, 6 \mathrm{H})$.

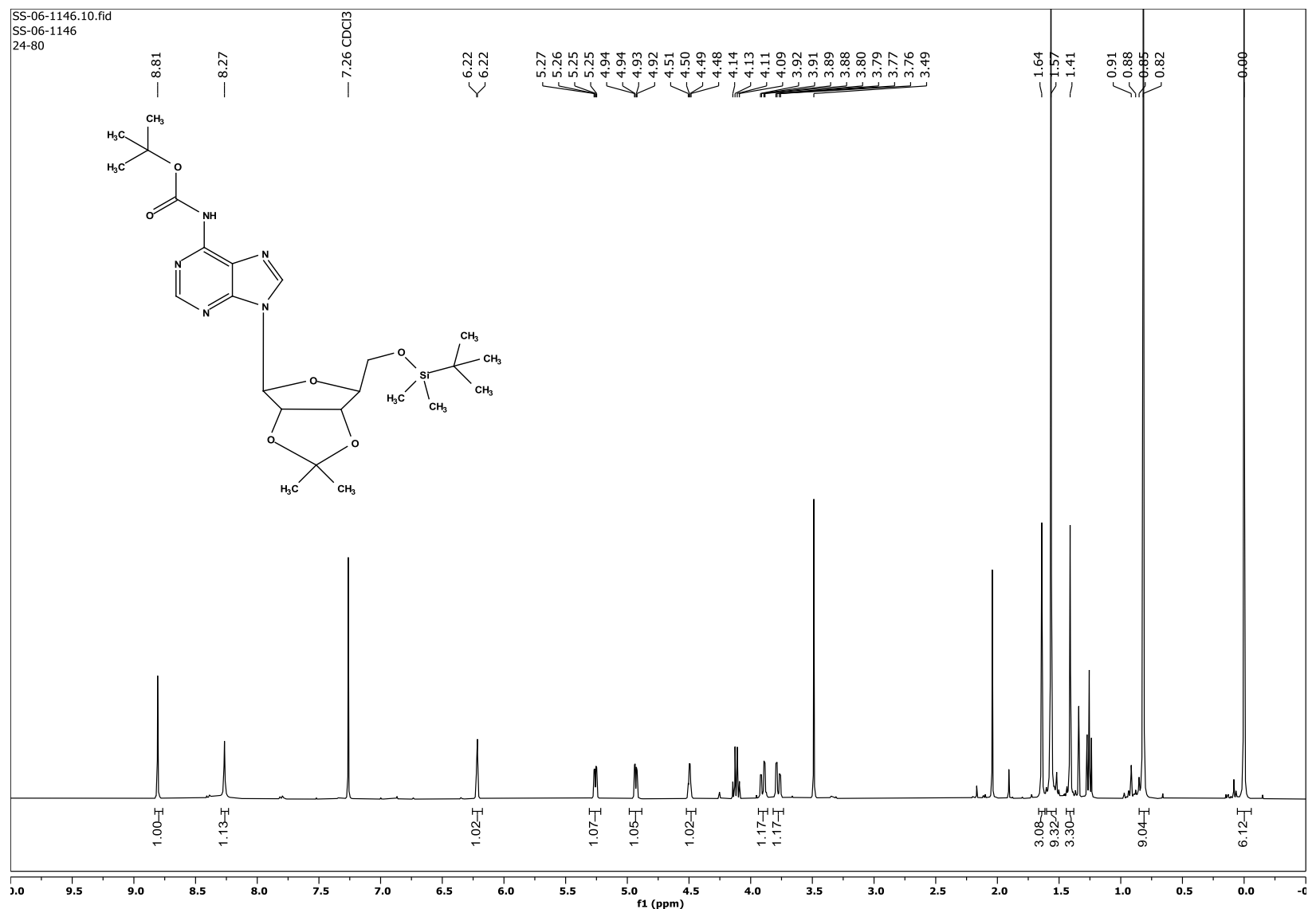




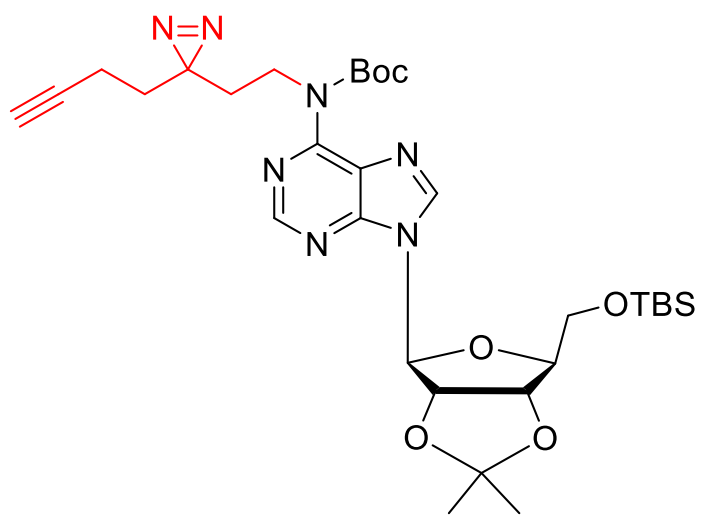

6A-4

6A-3 (0.57 g, $1.09 \mathrm{mmol})$ was dissolved in dry THF and were added $\mathrm{PPh}_{3}(0.43 \mathrm{~g}, 1.63 \mathrm{mmol})$ and 2-(3(but-3-yn-1-yl)-3H-diazirin-3-yl)ethan-1-ol $(0.22 \mathrm{~g}, 1.63 \mathrm{mmol})$. Stirred the mixture at $45^{\circ} \mathrm{C}$ for 2 mins and then added DIAD $(0.33 \mathrm{ml}, 1.63 \mathrm{mmol})$ in 30 secs. After stirring the mixture at $45^{\circ} \mathrm{C}$ for $1 \mathrm{~h}$ TLC showed the completion of reaction. Evaporated the solvent and the crude residue was purified via a Combiflash Companion system (EtOAc/Hexanes) to yield the product (0.66 g, 95\%).

${ }^{1}$ H NMR (400 MHz, CDCl3) $\delta 8.71(\mathrm{~s}, 1 \mathrm{H}), 8.25(\mathrm{~s}, 1 \mathrm{H}), 6.20(\mathrm{~d}, J=2.6 \mathrm{~Hz}, 1 \mathrm{H}), 5.19(\mathrm{dd}, J=6.2,2.6 \mathrm{~Hz}, 1 \mathrm{H})$, $4.98-4.89(\mathrm{~m}, 1 \mathrm{H}), 4.39(\mathrm{q}, J=3.9 \mathrm{~Hz}, 1 \mathrm{H}), 3.99-3.90(\mathrm{~m}, 2 \mathrm{H}), 3.85(\mathrm{dd}, J=11.2,3.9 \mathrm{~Hz}, 1 \mathrm{H}), 3.75(\mathrm{dd}, J=11.2$, $4.2 \mathrm{~Hz}, 1 \mathrm{H}), 1.97$ (td, $J=7.5,2.5 \mathrm{~Hz}, 3 \mathrm{H}), 1.90(\mathrm{t}, J=2.6 \mathrm{~Hz}, 1 \mathrm{H}), 1.81-1.72(\mathrm{~m}, 2 \mathrm{H}), 1.66(\mathrm{qd}, J=7.9,7.4,4.8 \mathrm{~Hz}$, $2 \mathrm{H}), 1.61(\mathrm{~s}, 3 \mathrm{H}), 1.43(\mathrm{~s}, 9 \mathrm{H}), 1.37$ (s, 3H), $0.83(\mathrm{~s}, 9 \mathrm{H}),-0.00(\mathrm{~d}, J=3.6 \mathrm{~Hz}, 6 \mathrm{H})$.

LR-MS (ESI) $\mathrm{m} / \mathrm{z}[\mathrm{M}+\mathrm{H}]^{+}$calculated for $\mathrm{C}_{31} \mathrm{H}_{48} \mathrm{~N}_{7} \mathrm{O}_{6} \mathrm{Si} 642.34$, observed 642.10 . 


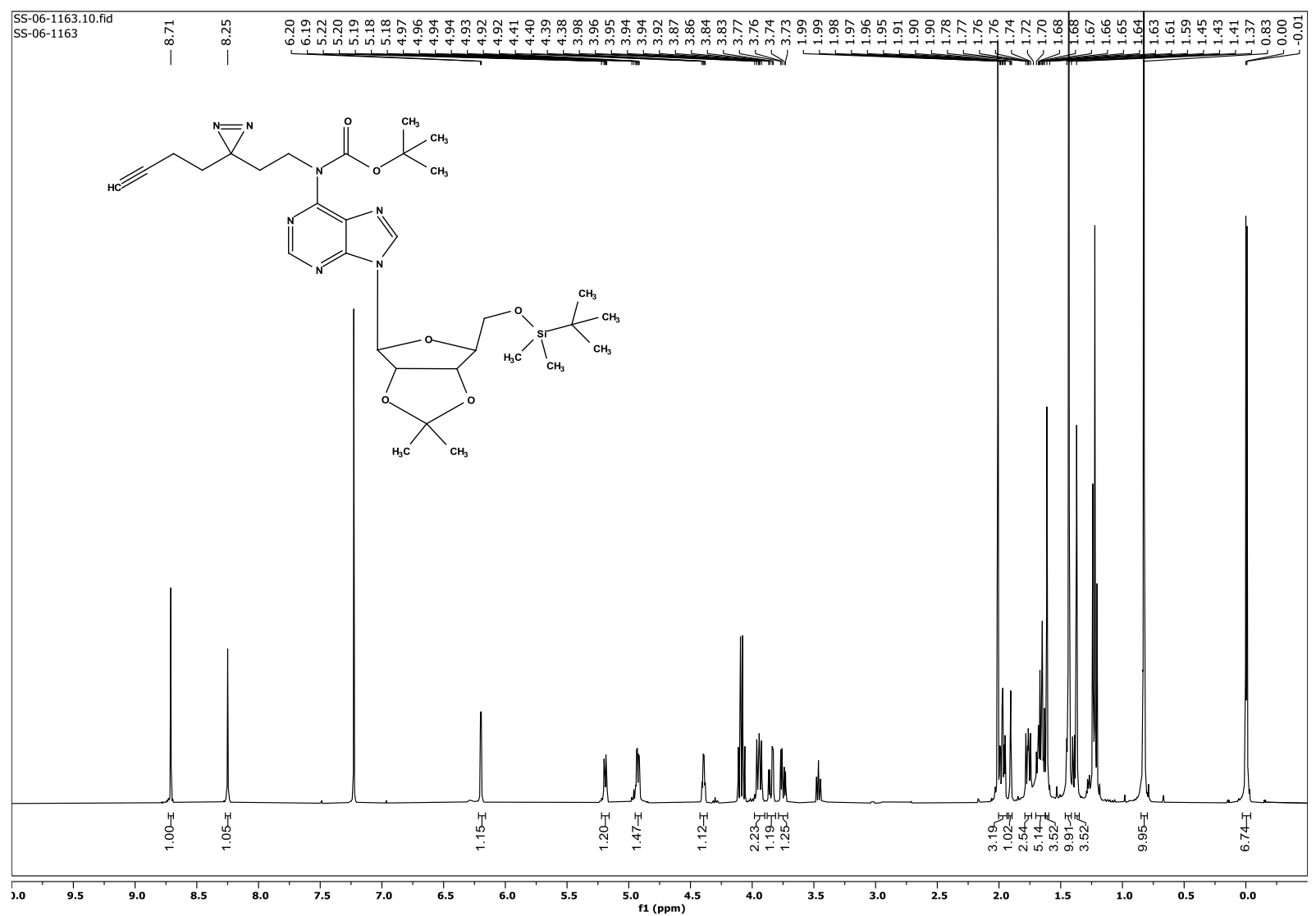




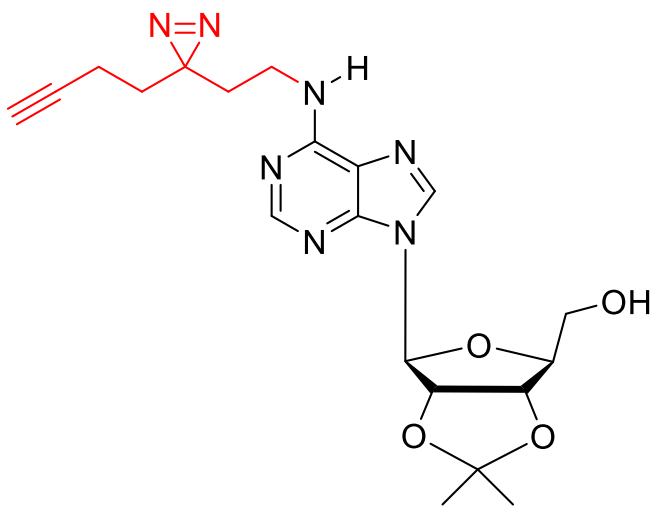

6A-5

6A-4 (0.53 g, $0.82 \mathrm{mmol})$ and $p$-TsOH. $\mathrm{H}_{2} \mathrm{O}(0.41 \mathrm{~g}, 0.5$ equiv. $)$ were dissolved in dry $\mathrm{MeOH}(6 \mathrm{~mL})$ and stirred the mixture at room temperature overnight to remove the TBS group and for $2 \mathrm{hrs}$ at $60{ }^{\circ} \mathrm{C}$ to remove the Boc group. After the complete deprotection monitored by TLC, the crude residue was purified via a Combiflash Companion system (EtOAc/Hexanes) to yield the product $(0.085 \mathrm{~g}, 25 \%)$.

${ }^{1}$ H NMR (400 MHz, CDCl $) \delta 8.32(\mathrm{~s}, 1 \mathrm{H}), 7.81(\mathrm{~s}, 1 \mathrm{H}), 6.07(\mathrm{~s}, 1 \mathrm{H}), 5.84(\mathrm{~d}, J=4.9 \mathrm{~Hz}, 1 \mathrm{H}), 5.19$ (t, $J$ $=5.4 \mathrm{~Hz}, 1 \mathrm{H}), 5.12-5.08(\mathrm{dd}, J=12.6,1.4 \mathrm{~Hz}, 1 \mathrm{H}), 4.53(\mathrm{~s}, 1 \mathrm{H}), 3.97(\mathrm{dd}, J=12.8,1.4 \mathrm{~Hz}, 1 \mathrm{H}), 3.78(\mathrm{~d}$, $J=12.7 \mathrm{~Hz}, 1 \mathrm{H}), 3.60-3.44(\mathrm{~m}, 2 \mathrm{H}), 2.06-1.97(\mathrm{~m}, 3 \mathrm{H}), 1.86(\mathrm{t}, J=6.9 \mathrm{~Hz}, 2 \mathrm{H}), 1.68(\mathrm{t}, J=7.2 \mathrm{~Hz}$, 2H), 1.64 (s, 3H), 1.37 (s, 3H).

LR-MS (ESI) m/z [M+H] $]^{+}$calculated for $\mathrm{C}_{20} \mathrm{H}_{26} \mathrm{~N}_{7} \mathrm{O}_{4}$ 428.2, observed 428.0.

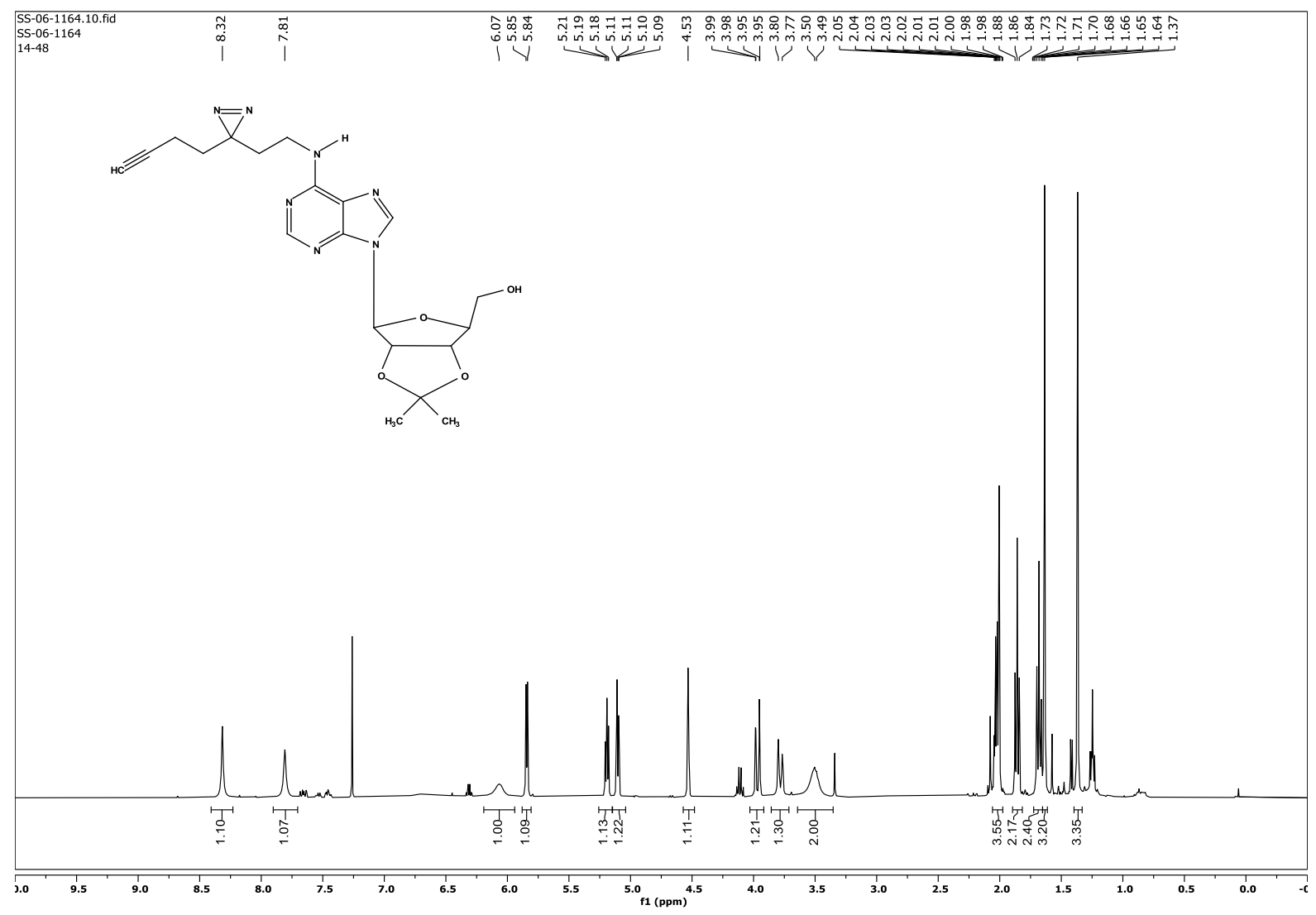




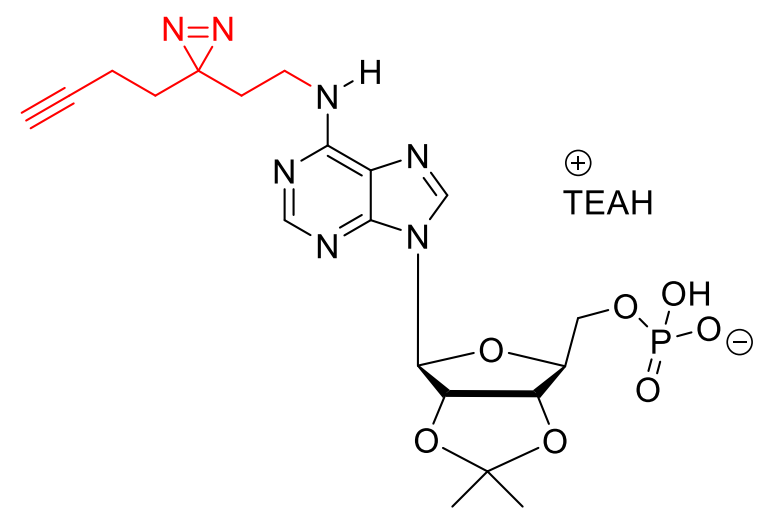

\section{A-6}

A solution of $6 \mathrm{~A}-5(0.0837 \mathrm{~g}, 0.19 \mathrm{mmol})$ dissolved in THF $(2.0 \mathrm{~mL})$ under argon was cooled to $0{ }^{\circ} \mathrm{C}$ and added triethylamine $\left(0.27 \mathrm{~mL}, 1.9 \mathrm{mmol}, 10\right.$ equiv.). After stirring for $10 \mathrm{mins}, \mathrm{POCl}_{3}(40 \mu \mathrm{L}, 0.4 \mathrm{mmol}, 2$ equiv.) was added dropwise solution turned cloudy. After 15 mins TLC showed the consumption of starting material. Immediately quenched the reaction with water $(1.0 \mathrm{~mL})$ and evaporated the solvents and coevaporated with acetonitrile to yield a solid. Dissolved the solid in minimum amount of methanol and subjected to C-18 column chromatography using $50 \mathrm{mM}$ TEAB buffer and methanol as the solvent system. The fractions containing the product were pooled together and evaporated the solvent to yield the desired compound 6A-6 (0.052 g, 44\%).

${ }^{1}$ H NMR (400 MHz, CDCl $) \delta 8.33(\mathrm{~s}, 1 \mathrm{H}), 8.22(\mathrm{~s}, 1 \mathrm{H}), 6.79(\mathrm{~s}, 1 \mathrm{H}), 6.12(\mathrm{~d}, J=2.7 \mathrm{~Hz}, 1 \mathrm{H}), 5.04(\mathrm{~s}$, $1 \mathrm{H}), 4.81(\mathrm{~m}, 1 \mathrm{H}), 4.39(\mathrm{~s}, 1 \mathrm{H}), 4.03-3.91(\mathrm{~m}, 2 \mathrm{H}), 3.38(\mathrm{~s}, 2 \mathrm{H}), 1.91-1.88(\mathrm{~m}, 2 \mathrm{H})$ overlapped, $1.72(\mathrm{t}$, $J=7.0 \mathrm{~Hz}, 2 \mathrm{H}), 1.56(\mathrm{t}, J=7.2 \mathrm{~Hz}, 2 \mathrm{H}), 1.48(\mathrm{~s}, 3 \mathrm{H}), 1.21(\mathrm{~s}, 3 \mathrm{H})$.

LR-MS (ESI) m/z [M] calculated for $\mathrm{C}_{20} \mathrm{H}_{26} \mathrm{~N}_{7} \mathrm{O}_{7} \mathrm{P}$ 507.16, observed 507.80. 


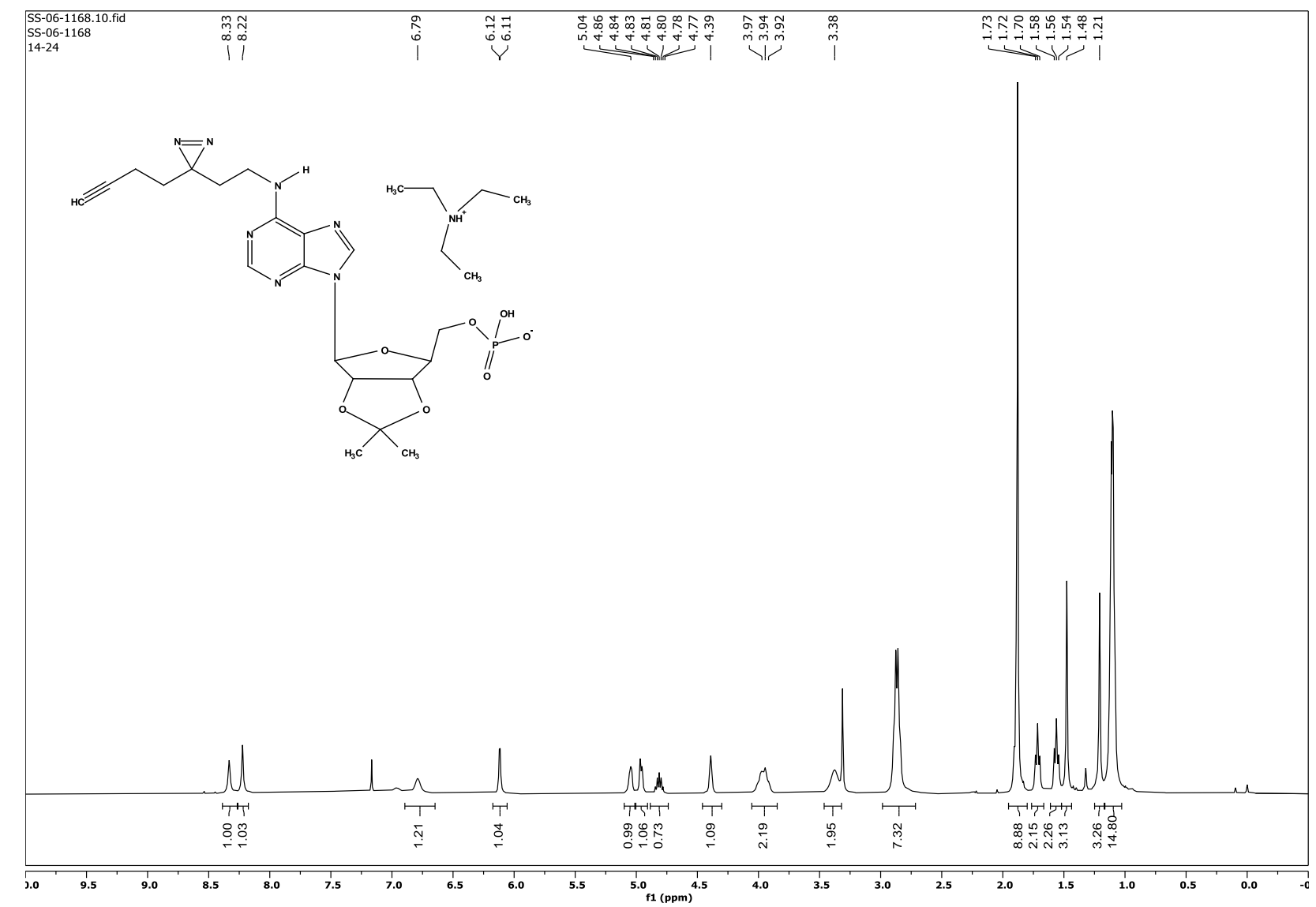




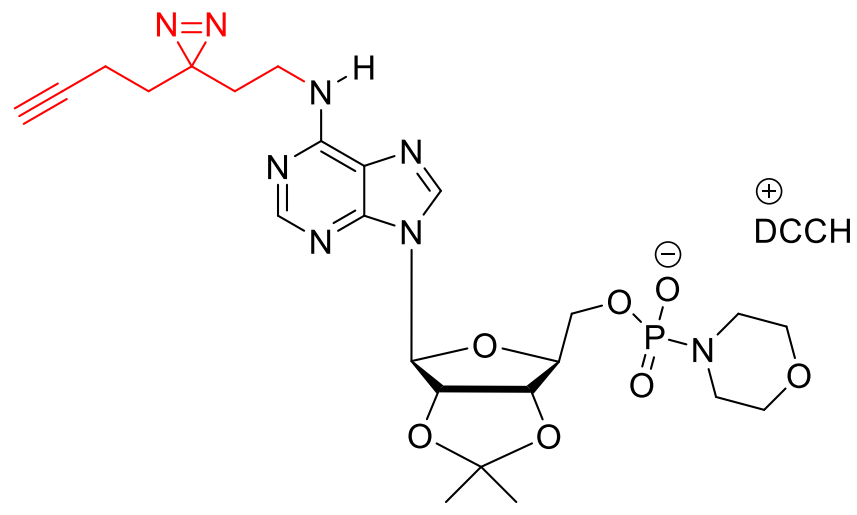

6A-7

6A-6 $(0.052 \mathrm{~g}, 0.086 \mathrm{mmol})$ was dissolved in $\mathrm{t}-\mathrm{BuOH}(5.0 \mathrm{~mL})$, followed by dropwise addition of morpholine ( $40 \mu \mathrm{L}, 0.43 \mathrm{mmol}, 5.0$ equiv). The reaction mixture was first stirred at RT for $15 \mathrm{~min}$ and then refluxed. Dicyclohexylcarbodiimide $(0.072 \mathrm{~g}, 0.34 \mathrm{mmol}, 4.0$ equiv) was dissolved in $t$ - $\mathrm{BuOH}(3.5 \mathrm{~mL})$ and divided into 10 aliquots. An aliquot was added dropwise to the reaction mixture under reflux every ten minutes. After $2 \mathrm{~h}$, DCC addition was complete and reflux was continued for another $5 \mathrm{~min}$. After reaction was completed, (as determined by MS analysis) the mixture was cooled and concentrated under vacuum. Addition of ether formed a precipitate, then the ether was decanted and fresh ether was added to wash the precipitate. The precipitate was dried under high vacuum to form 6A-7 as an off-white powder in quantitative yield. The crude was used in the coupling step without further purification.

LR-MS (ESI) m/z [M] ${ }^{+}$calculated for $\mathrm{C}_{24} \mathrm{H}_{33} \mathrm{~N}_{8} \mathrm{O}_{7} \mathrm{P} 576.22$, observed 576.80. 


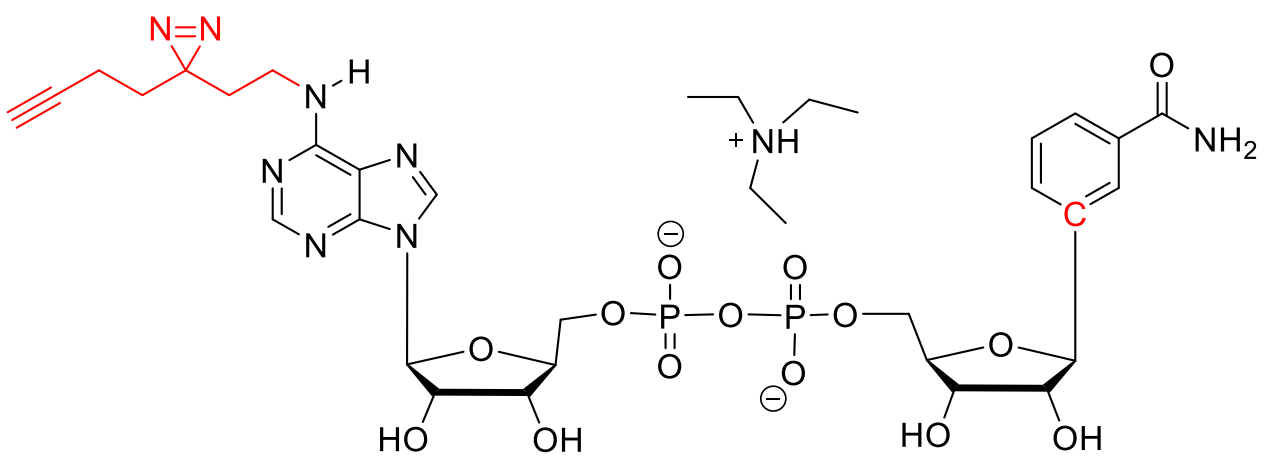

6-ad-BAD

6-diaziridylalkyne AMP-morpholidate 6A-7 (0.074 g, $0.05 \mathrm{mmol}), \mathbf{B 4}$ (0.134 g, $0.17 \mathrm{mmol}, 2.0$ equiv), and $\mathrm{MgSO}_{4}$ (24 mg, $0.17 \mathrm{mmol}, 2.0$ equiv) were dissolved in a solution of $\mathrm{MnCl}_{2}$ (2.0 ml, $0.2 \mathrm{M}$ in formamide) and stirred at room temperature for overnight. After the completion of the coupling reaction monitored by MS, $\mathrm{H}_{2} \mathrm{O}(4.0 \mathrm{~mL})$ was added. To this mixture) was added DOWEX 50x (1.0 g) and the mixture was stirred overnight at RT. After the complete deprotection of acetonide groups (monitored by MS), the resin was filtered off and the aqueous solution was concentrated to dryness. Methanol $(5 \mathrm{~mL})$ was added to form a cloudy suspension and the reaction was centrifuged to separate the precipitate. The methanol layer was then evaporated to dryness and the resultant solid was further washed with acetone $(4.0 \mathrm{~mL})$ and decanted. The solid was again resuspended in methanol and the crude product was purified via preparative HPLC using $50 \mathrm{mM}$ TEAB buffer and acetonitrile. The fraction containing the product were pooled and concentrated to yield the product as TEA salt $(2.4 \mathrm{mg})$.

${ }^{1}$ H NMR (400 MHz, D $\mathbf{2}$ ) $\delta 8.21(\mathrm{~s}, 1 \mathrm{H}), 8.07(\mathrm{~s}, 1 \mathrm{H}), 7.58(\mathrm{~s}, 1 \mathrm{H}), 7.47(\mathrm{~d}, J=7.2 \mathrm{~Hz}, 1 \mathrm{H}), 7.38(\mathrm{~s}$, $1 \mathrm{H}), 7.22(\mathrm{~s}, 1 \mathrm{H}), 6.07(\mathrm{~s}, 1 \mathrm{H}), 5.95(\mathrm{~s}, 1 \mathrm{H}), 4.16(\mathrm{~s}, 6 \mathrm{H}), 3.92(\mathrm{~s}, 2 \mathrm{H}), 3.55-3.53(\mathrm{~m}, 2 \mathrm{H}), 3.41(\mathrm{~s}, 2 \mathrm{H})$ $3.30(\mathrm{dd}, J=15.7,8.6 \mathrm{~Hz}, 2 \mathrm{H}), 2.25-2.14(\mathrm{~m}, 2 \mathrm{H}), 1.94-1.90(\mathrm{~m}, 2 \mathrm{H}), 1.83-1.77(\mathrm{~m}, 3 \mathrm{H}), 1.62(\mathrm{~m}, 2 \mathrm{H})$. Peaks missing are due to overlapping signal of $\mathrm{D}_{2} \mathrm{O}$.

LR-MS (ESI) m/z [M] calculated for $\mathrm{C}_{29} \mathrm{H}_{35} \mathrm{~N}_{8} \mathrm{O}_{14} \mathrm{P}_{2}$ 782.18, observed 782.80. 


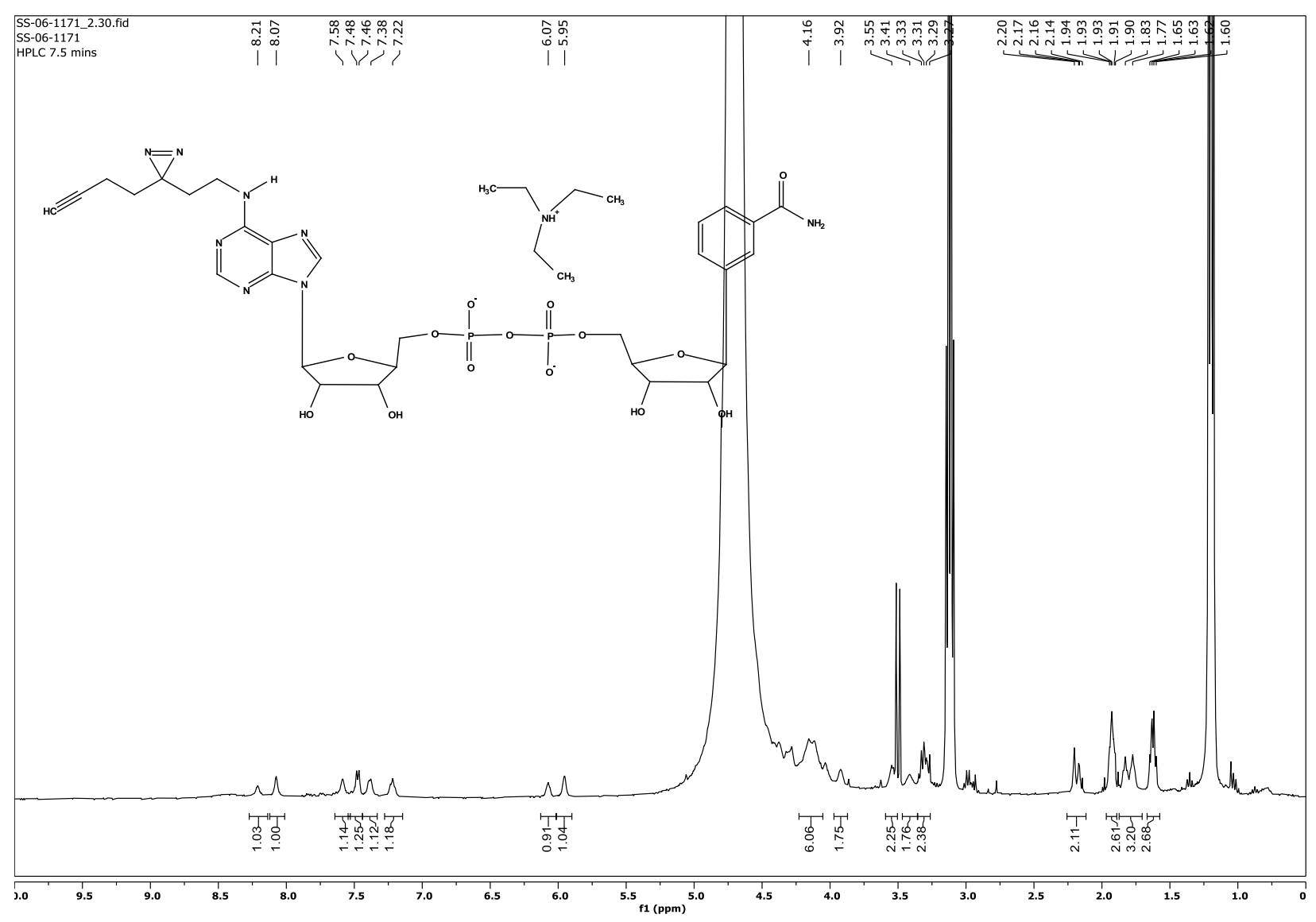




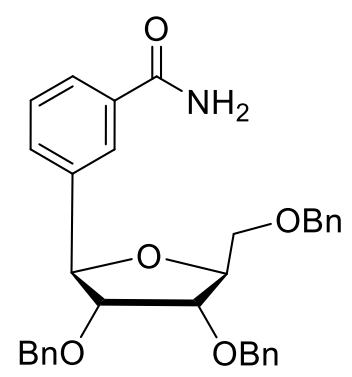

B1

This compound was prepared using previously published procedure ${ }^{7}$.

${ }^{1}$ H NMR (400 MHz, CDCl3) $\delta 7.82-7.76(\mathrm{~m}, 2 \mathrm{H}), 7.53(\mathrm{~d}, J=7.6 \mathrm{~Hz}, 1 \mathrm{H}), 7.43-7.16(\mathrm{~m}, 17 \mathrm{H}), 5.78$ $(\mathrm{s}, 1 \mathrm{H}), 5.38(\mathrm{~s}, 1 \mathrm{H}), 5.09(\mathrm{~d}, J=6.4 \mathrm{~Hz}, 1 \mathrm{H}), 4.76-4.43(\mathrm{~m}, 7 \mathrm{H}), 4.42-4.35(\mathrm{~m}, 1 \mathrm{H}), 4.09(\mathrm{t}, J=4.6 \mathrm{~Hz}$, $1 \mathrm{H}), 3.87-3.82(\mathrm{~m}, 1 \mathrm{H}), 3.78(\mathrm{dd}, J=10.5,3.7 \mathrm{~Hz}, 1 \mathrm{H}), 3.68(\mathrm{dd}, J=10.5,3.4 \mathrm{~Hz}, 1 \mathrm{H})$. 


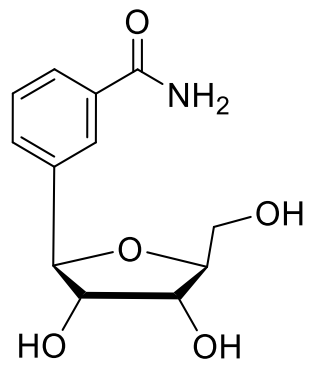

B2

This compound was prepared using previously published procedure ${ }^{8}$.

B1 $(0.98 \mathrm{~g}, 1.88 \mathrm{mmol})$ was dissolved in dry DCM $(38 \mathrm{~mL})$ under nitrogen at $-78^{\circ} \mathrm{C}$ and a $1 \mathrm{~N}$ solution of $\mathrm{BBr}_{3}$ in $\mathrm{DCM}(7.6 \mathrm{~mL})$ was added slowly. The reaction was stirred for 1 hour at $-78^{\circ} \mathrm{C}$ and then overnight warming to room temperature. The reaction was quenched with a mixture of $\mathrm{Et}_{2} \mathrm{O}$ and $\mathrm{MeOH}(4 / 1,40 \mathrm{~mL})$, stirred for 20 minutes, and concentrated. The crude residue was purified via a Combiflash Companion system using DCM-MeOH (4:1). Fractions containing the desired product were treated with charcoal and filtered through celite pad which was then concentrated to yield a white solid $(0.417 \mathrm{~g}, 87 \%)$.

${ }^{1}$ H NMR (400 MHz, DMSO) $\delta 7.94(\mathrm{~s}, 1 \mathrm{H}), 7.85(\mathrm{~s}, 1 \mathrm{H}), 7.76(\mathrm{~d}, \mathrm{~J}=7.6 \mathrm{~Hz}, 1 \mathrm{H}), 7.55(\mathrm{~d}, \mathrm{~J}=7.5 \mathrm{~Hz}$, $1 \mathrm{H}), 7.40(\mathrm{t}, \mathrm{J}=7.6 \mathrm{~Hz}, 1 \mathrm{H}), 7.34(\mathrm{~s}, 1 \mathrm{H}), 4.59(\mathrm{~d}, \mathrm{~J}=7.1 \mathrm{~Hz}, 1 \mathrm{H}), 3.97-3.87(\mathrm{~m}, 2 \mathrm{H}), 3.83(\mathrm{~d}, \mathrm{~J}=3.7$ $\mathrm{Hz}, 1 \mathrm{H}), 3.75-3.66(\mathrm{~m}, 3 \mathrm{H}), 3.56(\mathrm{t}, \mathrm{J}=5.0 \mathrm{~Hz}, 2 \mathrm{H})$.

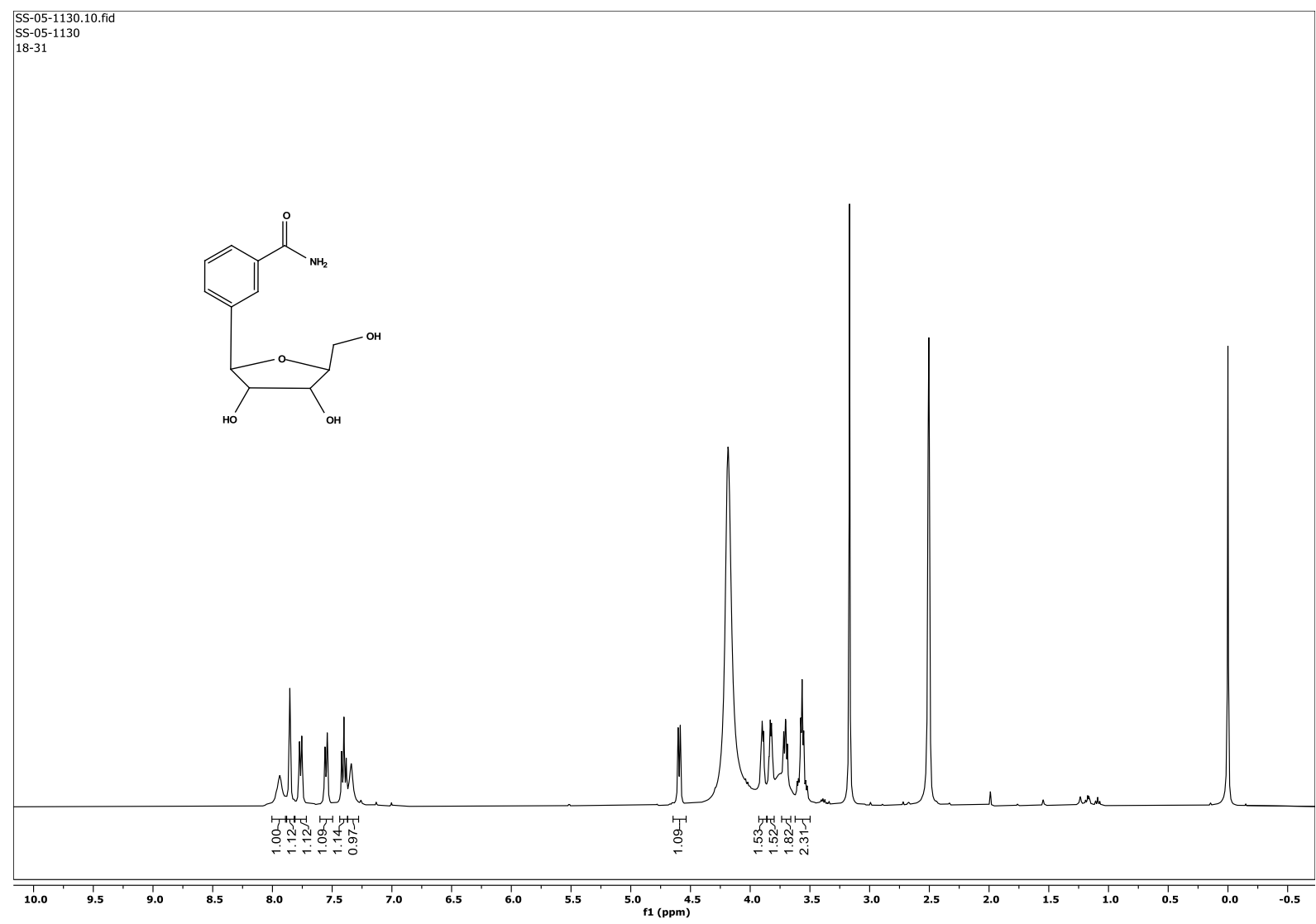




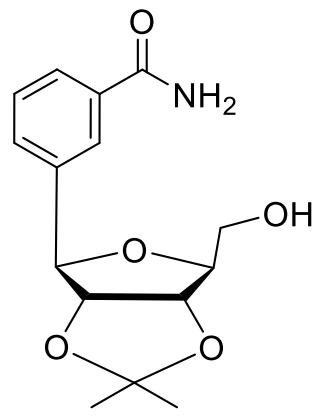

B3

B2 was suspended in acetone $(40 \mathrm{~mL})$ and cooled to $0^{\circ}$ C. $p$-TsOH. $\mathrm{H}_{2} \mathrm{O}(1.54 \mathrm{~g}, 8.09 \mathrm{mmol}, 5$ equiv. $)$ was added and stirred the mixture at RT overnight. Upon completion of the reaction (monitored by TLC), it was quenched and neutralized with sat. $\mathrm{NaHCO}_{3}$ and the precipitate formed was filtered out and diluted and extracted with $\mathrm{CHCl}_{3}\left(3 \times 50 \mathrm{~mL}\right.$ ). The organic layer was dried over $\mathrm{MgSO}_{4}$ and then concentrated and dried under high vacuum to yield an off white solid $(0.37 \mathrm{~g}, 80 \%)$.

${ }^{1}$ H NMR (400 MHz, CDCl $) \delta 7.85(\mathrm{~s}, 1 \mathrm{H}), 7.65(\mathrm{~d}, \mathrm{~J}=7.8 \mathrm{~Hz}, 1 \mathrm{H}), 7.42(\mathrm{~s}, 1 \mathrm{H}), 7.28(\mathrm{t}, \mathrm{J}=7.7 \mathrm{~Hz}, 1 \mathrm{H})$, $6.90(\mathrm{~s}, 1 \mathrm{H}), 6.39(\mathrm{~s}, 1 \mathrm{H}), 4.79(\mathrm{~d}, \mathrm{~J}=5.4 \mathrm{~Hz}, 1 \mathrm{H}), 4.67(\mathrm{dd}, \mathrm{J}=6.9,4.1 \mathrm{~Hz}, 1 \mathrm{H}), 4.40(\mathrm{dd}, \mathrm{J}=6.7,5.6 \mathrm{~Hz}$, 1H), $4.08(\mathrm{~d}, \mathrm{~J}=2.9 \mathrm{~Hz}, 1 \mathrm{H}), 3.83(\mathrm{~d}, \mathrm{~J}=2.7 \mathrm{~Hz}, 2 \mathrm{H}), 3.68(\mathrm{dd}, \mathrm{J}=12.1,4.1 \mathrm{~Hz}, 1 \mathrm{H}), 1.53(\mathrm{~s}, 3 \mathrm{H}), 1.25$ (s, 3H). LR-MS (ESI) m/z [M-H] ${ }^{-}$calculated for $\mathrm{C}_{15} \mathrm{H}_{19} \mathrm{NO}_{5}{ }^{-}$292.1, observed 292.7.

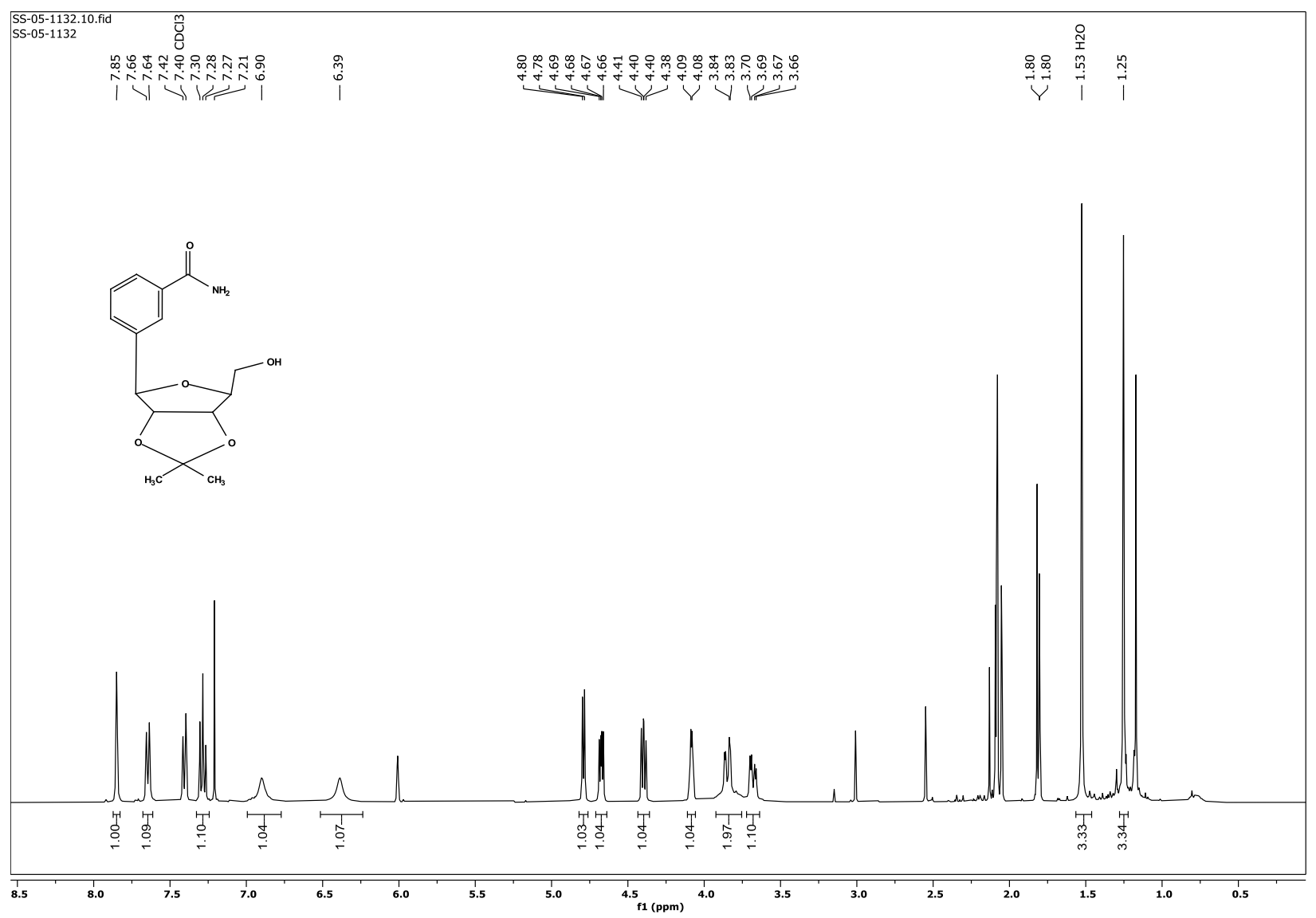




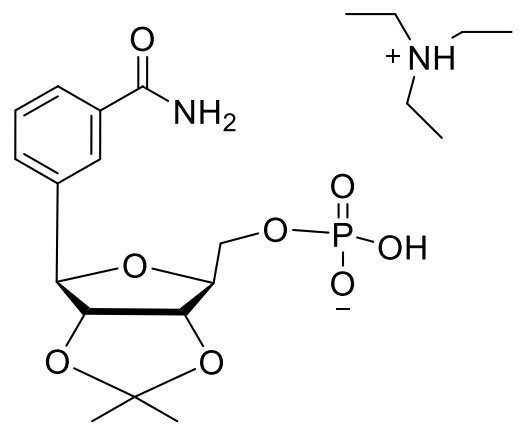

B4 (BMN)

A solution of $\mathbf{B 3}(0.080 \mathrm{~g}, 0.27 \mathrm{mmol})$ dissolved in THF $(2.7 \mathrm{~mL})$ under argon was cooled to $0{ }^{\circ} \mathrm{C}$ and added triethylamine $(0.38 \mathrm{~mL}, 2.7 \mathrm{mmol}, 10$ equiv. $)$. After stirring for $10 \mathrm{mins}, \mathrm{POCl}_{3}(51 \mu \mathrm{L}, 0.54 \mathrm{mmol}$, 2 equiv.) was added dropwise solution turned cloudy. After 15 mins TLC showed the consumption of starting material. Immediately quenched the reaction with water $(1.0 \mathrm{~mL})$, evaporated the solvents, and coevaporated with acetonitrile to yield a solid. Dissolved the solid in minimum amount of $\mathrm{CHCl}_{3}$ and subjected to flash column chromatography using $\mathrm{DCM} / \mathrm{MeOH}$ as the solvent system. The fractions containing the product were pooled together and evaporated the solvent to yield the desired compound (62.6 $\mathrm{mg}, 49 \%)$.

${ }^{1}$ H NMR (400 MHz, MeOD-d 1 ) $\delta 7.63(\mathrm{~m}, 2 \mathrm{H}), 7.60$ (d, J = $\left.7.8 \mathrm{~Hz}, 1 \mathrm{H}\right), 7.52-7.46(\mathrm{~m}, 1 \mathrm{H}), 4.84$ - 4.80 $(\mathrm{m}, 1 \mathrm{H}), 4.75(\mathrm{dt}, \mathrm{J}=6.7,3.4 \mathrm{~Hz}, 1 \mathrm{H}), 4.48-4.43(\mathrm{~m}, 1 \mathrm{H}), 4.24(\mathrm{dd}, \mathrm{J}=3.7,1.7 \mathrm{~Hz}, 1 \mathrm{H}), 4.12(\mathrm{dt}, \mathrm{J}=6.7$, $3.5 \mathrm{~Hz}, 2 \mathrm{H}), 3.65$ (d, J = 2.7 Hz, 2H), 3.62 (d, J = 2.6 Hz, 2H), 1.54 (s, 3H), 1.29 (s, 3H). LR-MS (ESI) m/z $[\mathrm{M}]^{+}$calculated for $\mathrm{C}_{15} \mathrm{H}_{20} \mathrm{NO}_{8} \mathrm{P}$ 373.1, observed 373.9.

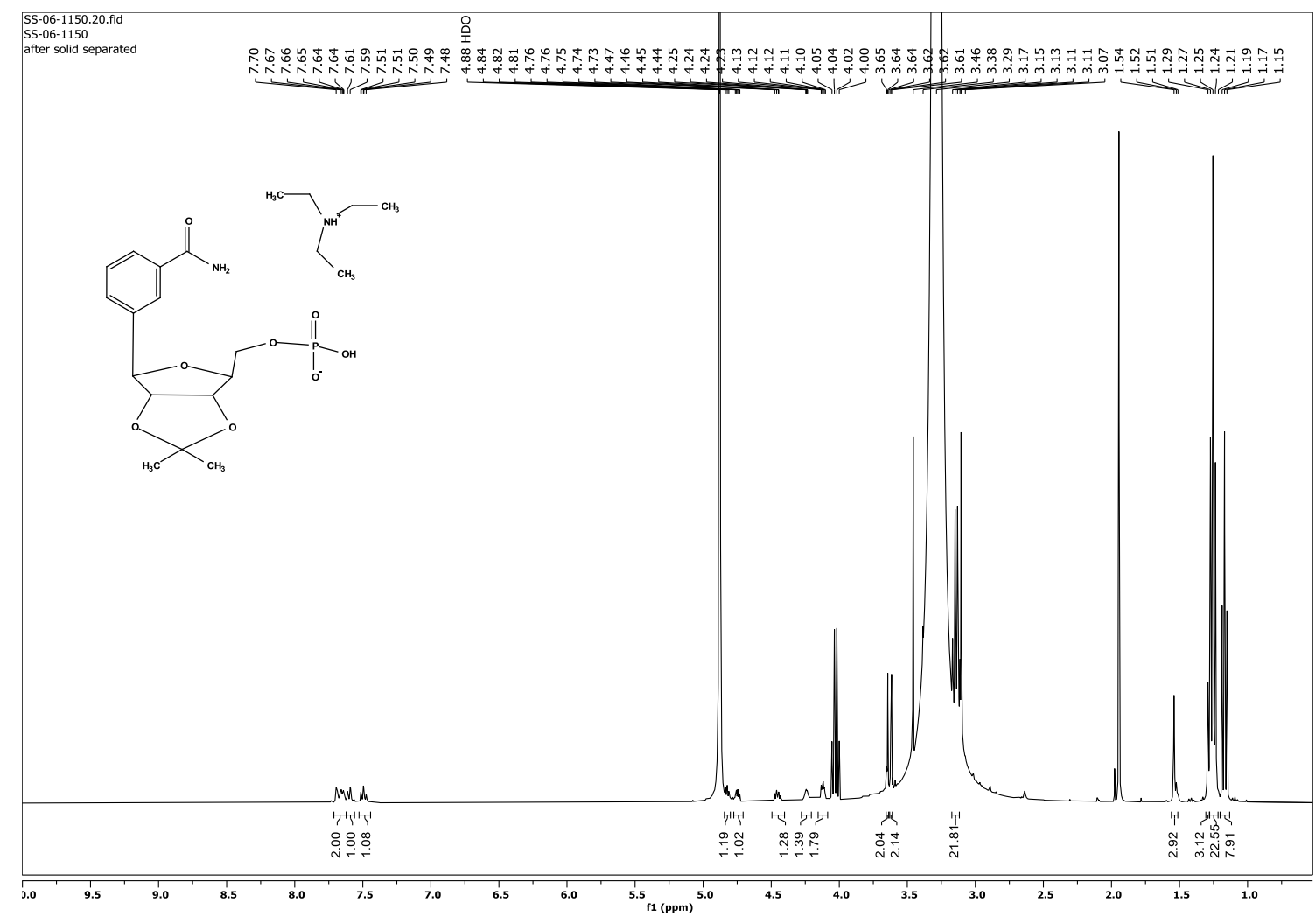




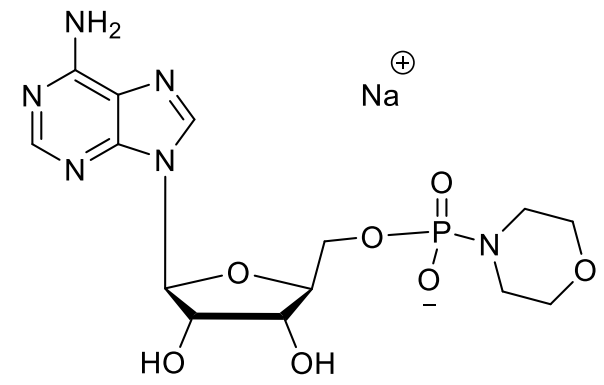

\section{AMP-Morpholidate}

AMP-Morpholidate was synthesized according to the literature procedure ${ }^{1}$.

${ }^{1} \mathbf{H}$ NMR (400 MHz, D2O) $\delta 8.35(\mathrm{~s}, 1 \mathrm{H}), 8.13(\mathrm{~s}, 1 \mathrm{H}), 6.03(\mathrm{~d}, \mathrm{~J}=5.0 \mathrm{~Hz}, 1 \mathrm{H}), 4.73-4.70(\mathrm{~m}, 2 \mathrm{H}$, overlapped by $\mathrm{D}_{2} \mathrm{O}$ peak) $4.45(\mathrm{t}, \mathrm{J}=4.7 \mathrm{~Hz}, 1 \mathrm{H}), 4.28(\mathrm{~s}, 1 \mathrm{H}), 3.95(\mathrm{dt}, \mathrm{J}=11.6,5.7 \mathrm{~Hz}, 2 \mathrm{H}), 3.48(\mathrm{t}, \mathrm{J}=$ $4.3 \mathrm{~Hz}, 4 \mathrm{H}), 2.85(\mathrm{t}, \mathrm{J}=4.0,2.4 \mathrm{~Hz}, 4 \mathrm{H}), 2.65(\mathrm{t}, 1 \mathrm{H})$.

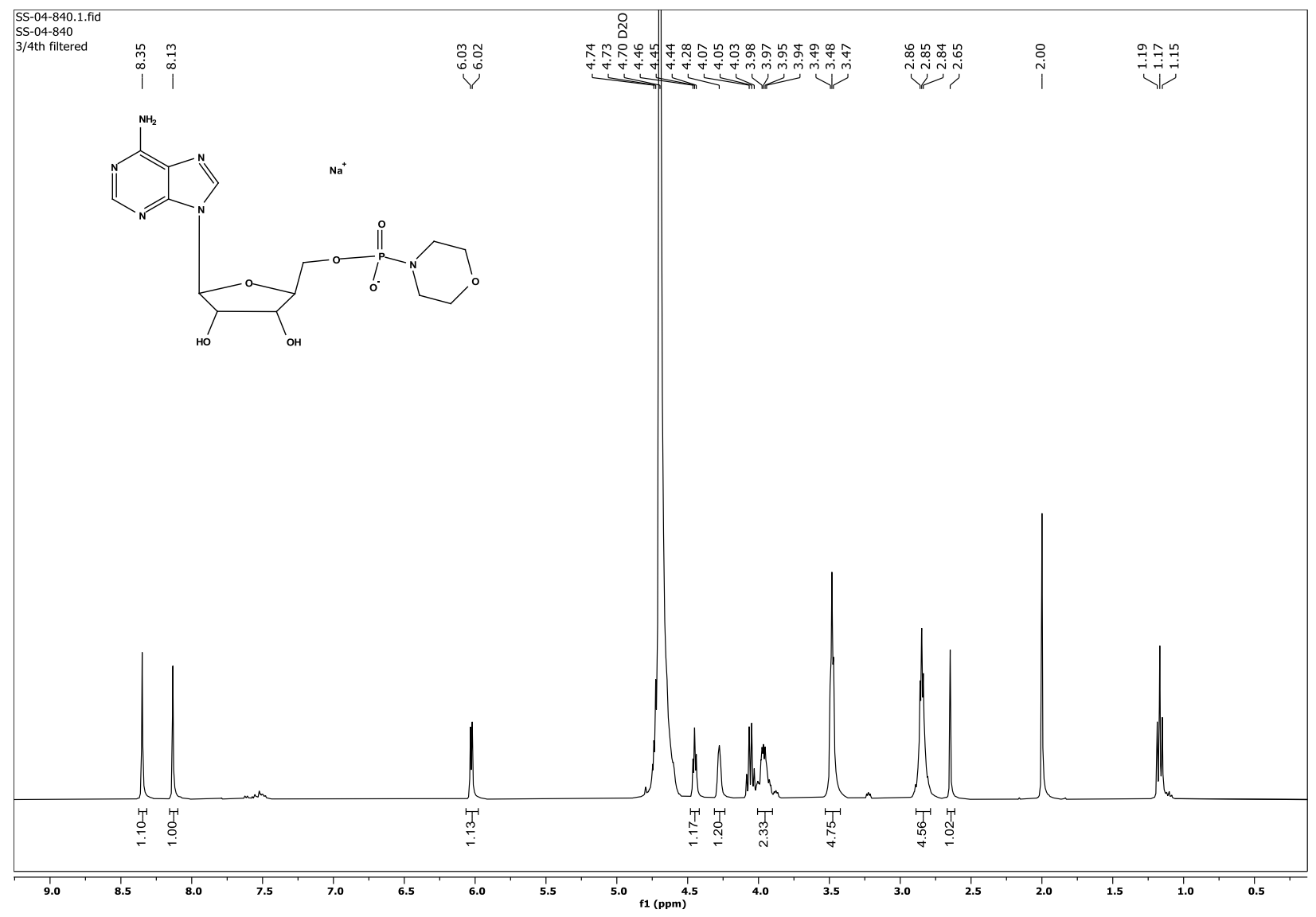




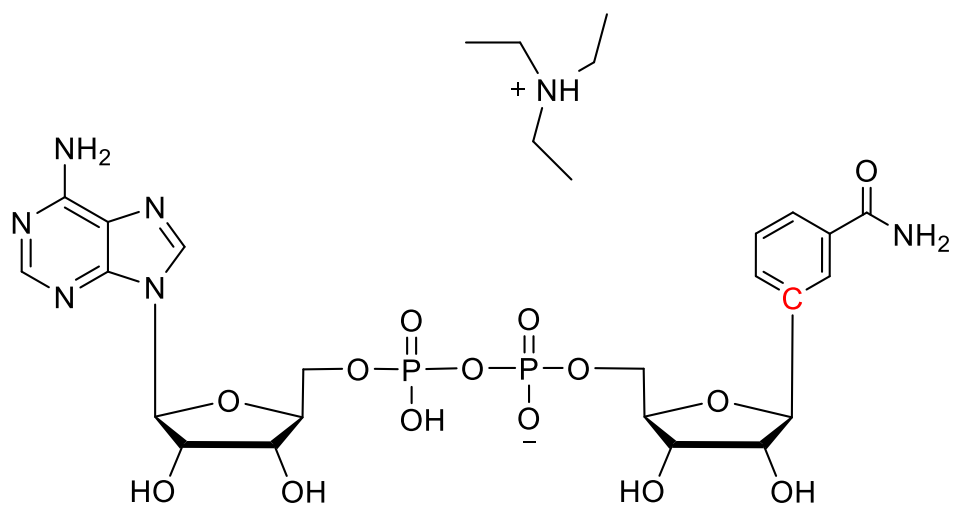

BAD

AMP-morpholidate (22.5 mg, $0.051 \mathrm{mmol}), \mathbf{B} 4$ (26.8 mg, $0.056 \mathrm{mmol}, 1.1$ equiv), and $\mathrm{MgSO}_{4}(12 \mathrm{mg}, 0.1$ mmol, 2.0 equiv) were dissolved in a solution of $\mathrm{MnCl}_{2}(0.4 \mathrm{ml}, 0.2 \mathrm{M}$ in formamide) and stirred at $\mathrm{RT}$ for overnight. After the completion of the coupling reaction monitored by $\mathrm{MS}, \mathrm{H}_{2} \mathrm{O}(4.0 \mathrm{~mL})$ was added. To this mixture DOWEX 50X (1.0 g) was added and stirred the mixture at RT overnight. After the complete deprotection of acetonide groups (monitored by MS), the resin was filtered off and the aqueous solution was concentrated to dryness and re-suspended in methanol and the crude product was purified via preparative HPLC using $50 \mathrm{mM}$ TEAB buffer and acetonitrile. The fraction containing the product were pooled and concentrated to yield the product as TEA salt $(7.0 \mathrm{mg})$.

${ }^{1}$ H NMR (400 MHz, D2O) $\delta 8.31(\mathrm{~s}, 1 \mathrm{H}), 8.07(\mathrm{~s}, 1 \mathrm{H}), 7.63(\mathrm{~s}, 1 \mathrm{H}), 7.51(\mathrm{~d}, \mathrm{~J}=7.9 \mathrm{~Hz}, 1 \mathrm{H}), 7.45(\mathrm{~d}, \mathrm{~J}=$ $7.7 \mathrm{~Hz}, 1 \mathrm{H}), 7.29(\mathrm{t}, \mathrm{J}=7.7 \mathrm{~Hz}, 1 \mathrm{H}), 5.94(\mathrm{~d}, \mathrm{~J}=5.5 \mathrm{~Hz}, 1 \mathrm{H}), 4.40-4.34(\mathrm{~m}, 2 \mathrm{H}), 4.27(\mathrm{~s}, 2 \mathrm{H}), 4.22-4.03$ $(\mathrm{m}, 6 \mathrm{H}), 3.96(\mathrm{dd}, \mathrm{J}=7.0,5.2 \mathrm{~Hz}, 1 \mathrm{H})$. Missing peaks are overlapped in the $\mathrm{D}_{2} \mathrm{O}$ signal. LR-MS $(\mathrm{ESI}) \mathrm{m} / \mathrm{z}$ $[\mathrm{M}]^{+}$calculated for $\mathrm{C}_{22} \mathrm{H}_{28} \mathrm{~N}_{6} \mathrm{O}_{14} \mathrm{P}_{2} 662.1$, observed 662.1. 


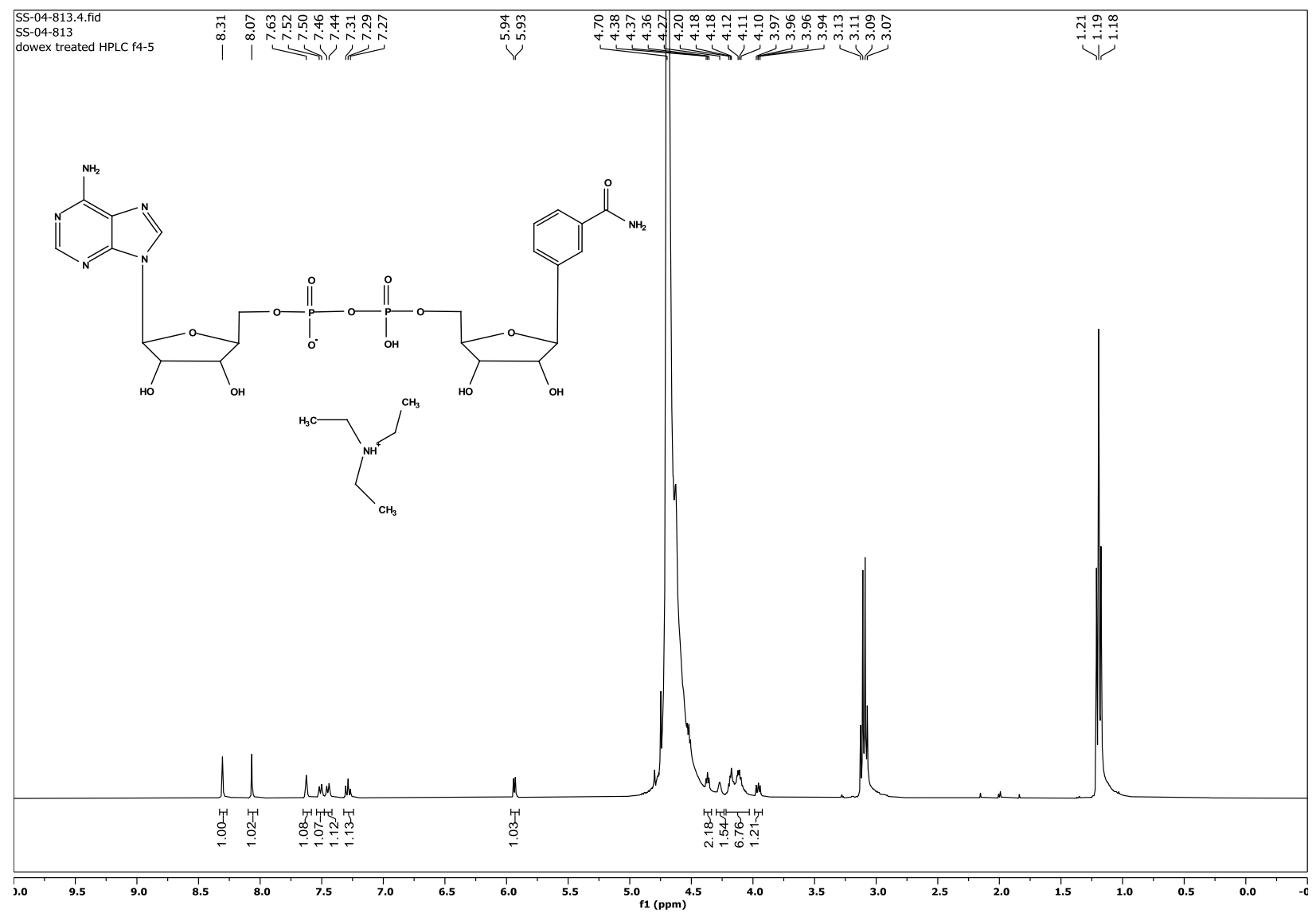


<smiles>CC(C)(C)OC(=O)N1CCN(C(=O)c2cc(Cc3n[nH]c(=O)c4ccccc34)ccc2F)CC1</smiles>

P1

2-fluoro-5-((4-oxo-3,4-dihydrophthalazin-1-yl)methyl)benzoic acid $(0.30 \mathrm{~g}, 1.0 \mathrm{mmol})$ and N-Boc piperizine $(0.186 \mathrm{~g}, 1.0 \mathrm{mmol}, 1.0$ equiv. $)$ were dissolved in DMF $(2.0 \mathrm{~mL})$. To this mixture was added T3P (1.2 mL, $2.0 \mathrm{mmol}, 2.0$ equiv.) and DIPEA (0.5 mL, $3.0 \mathrm{mmol}$. 3.0 equiv.). The resulting mixture was stirred at room temperature for $2 \mathrm{~h}$. Upon reaction completion monitored by TLC, the mixture was diluted with ethyl acetate, washed with sat. $\mathrm{NaHCO}_{3}, \mathrm{H}_{2} \mathrm{O}$ and brine. The organic layer was passed through a silica plug, dried over $\mathrm{MgSO}_{4}$ and concentrated to yield 1 as white solid $(0.393 \mathrm{~g}, 84 \%)$.

${ }^{1}$ H NMR (400 MHz, Chloroform- $d$ ) $\delta 10.46(\mathrm{~s}, 1 \mathrm{H}) 8.54-8.42(\mathrm{~m}, 1 \mathrm{H}), 7.86-7.65(\mathrm{~m}, 3 \mathrm{H}), 7.33(\mathrm{~m}$, $2 \mathrm{H}), 7.08-7.01(\mathrm{t}, \mathrm{J}=8.5 \mathrm{~Hz}, 1 \mathrm{H}), 4.30(\mathrm{~s}, 2 \mathrm{H}), 3.76(\mathrm{br}, 2 \mathrm{H}), 3.53(\mathrm{br}, 2 \mathrm{H}), 3.39(\mathrm{t}, \mathrm{J}=4.71 \mathrm{~Hz}, 2 \mathrm{H}), 3.28$ (br, 2H), 1.48 (s, 9H). LR-MS (ESI) m/z [M-H] ${ }^{-}$calculated for $\mathrm{C}_{25} \mathrm{H}_{26} \mathrm{FN}_{4} \mathrm{O}_{4}{ }^{-}$465.2, observed 465.1.

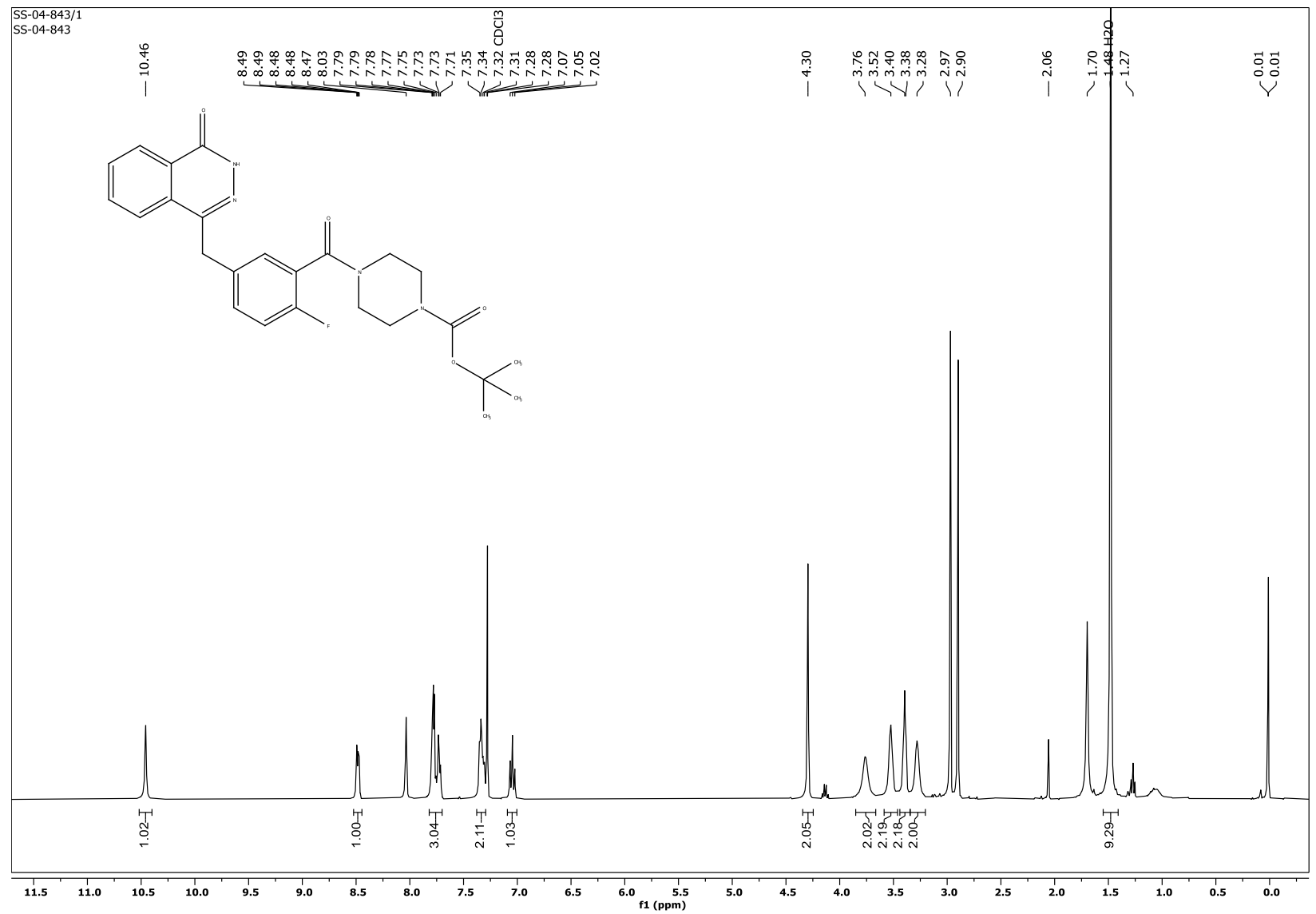


<smiles>O=C(c1cc(Cc2n[nH]c(=O)c3ccccc23)ccc1F)N1CCNCC1</smiles>

$\mathbf{P 2}$

To a suspension of $\mathbf{P 1}(0.39 \mathrm{~g}, 0.83 \mathrm{mmol})$ in ethanol $(20 \mathrm{~mL})$ were added $6 \mathrm{~N} \mathrm{HCl}$ in dioxane $(4.1 \mathrm{~mL})$ and stirred the mixture at $\mathrm{rt}$ for overnight. Upon the completion of the reaction, monitored by TLC, the solvent was evaporated and further co-evaporated with acetonitrile to form an oily residue. The oily residue was dissolved in a small amount of methanol and triturated. Evaporation of the solvent yielded a yellow crystalline powder $(0.215 \mathrm{~g}, 70 \%)$

${ }^{1}$ H NMR (400 MHz, DMSO-d $\left.\boldsymbol{d}_{6}\right) \delta 12.59$ (s, 1H), 9.49 (s, 1H), $8.26(\mathrm{~d}, J=7.6 \mathrm{~Hz}, 1 \mathrm{H}), 8.01-7.75$ (m, $3 \mathrm{H}), 7.51-7.35$ (m, 2H), 7.25 (t, $J=8.9 \mathrm{~Hz}, 1 \mathrm{H}), 4.33$ (s, 2H), 3.84 (br, 2H), 3.43 (br, 2H), 3.17 (br, 2H), 3.00 (br, 2H). LR-MS (ESI) m/z [M] ${ }^{+}$calculated for $\mathrm{C}_{20} \mathrm{H}_{19} \mathrm{FN}_{4} \mathrm{O}_{2} 366.1$, observed 366.9

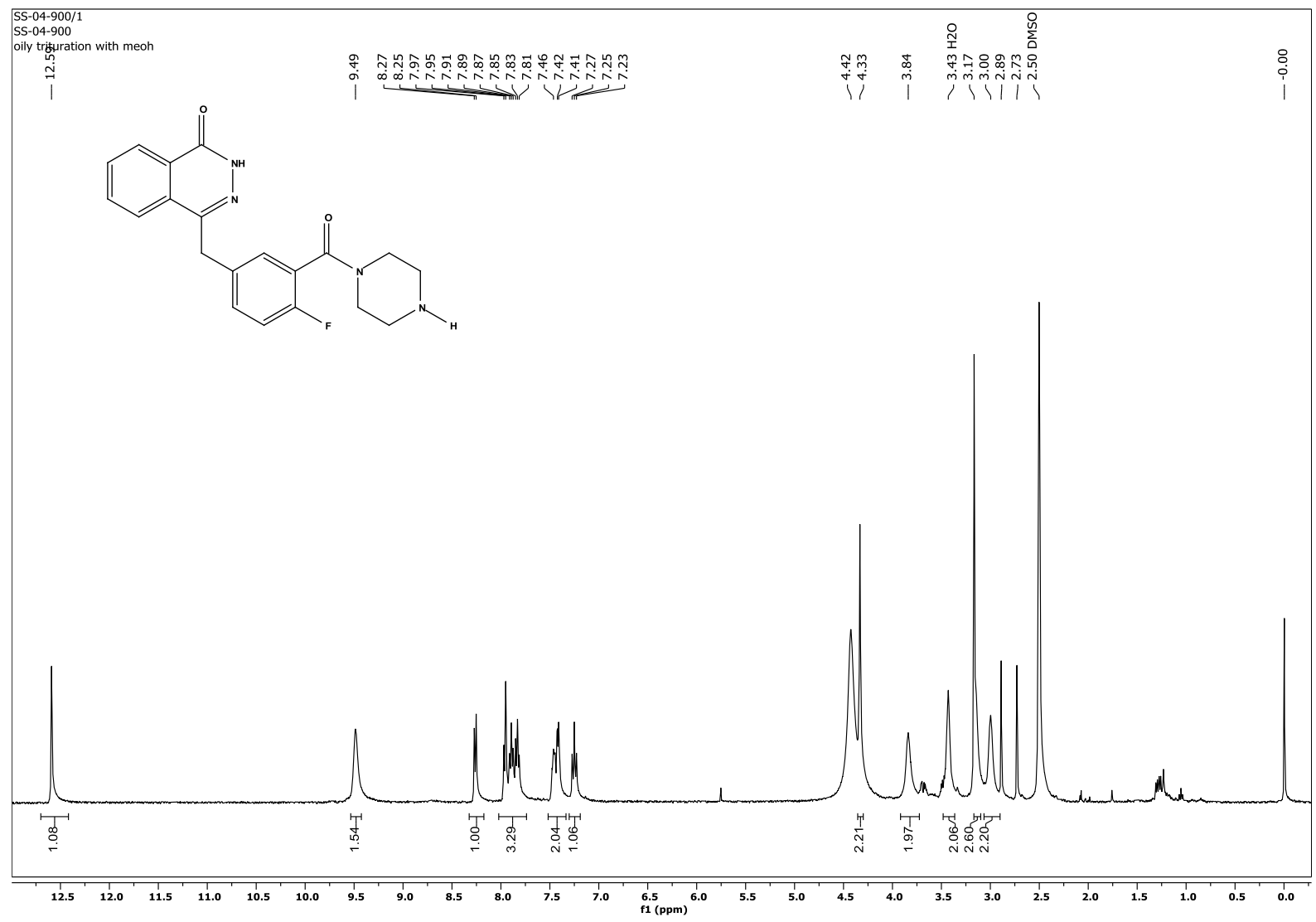




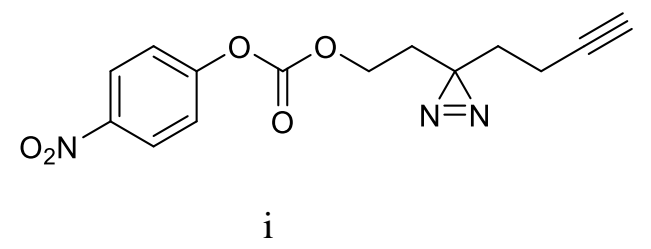

2-(3-(but-3-yn-1-yl)-3H-diazirin-3-yl)ethan-1-ol (0.03 g, $0.217 \mathrm{mmol})$ was dissolved in dry acetonitrile (1.0 $\mathrm{mL}$ ) and cooled to $0^{\circ} \mathrm{C}$. Added pyridine $(0.035 \mathrm{~mL}, 0.434 \mathrm{mmol}, 2.0$ equiv.) and stirred for 15 mins. A solution of 4-nitrophenylchloroformate $(0.66 \mathrm{~g}, 0.32 \mathrm{mmol}, 1.5$ equiv. $)$ dissolved in acetonitrile $(1 \mathrm{~mL})$ was added dropwise to the above mixture and the reaction was warmed to room temperature and stirred overnight. The reaction was then concentrated and quenched with water, extracted with ethyl acetate $(2 \times 5$ $\mathrm{mL}$ ), dried over $\mathrm{MgSO}_{4}$ and concentrated. The crude product was purified via a Combiflash Companion system (24g Redisep Rf Normal Phase; MP A: hexanes, MP B: Ethyl acetate) to yield the product which was contaminated with nitrophenol derivative was used in the next step without further purification.

${ }^{1}$ H NMR (400 MHz, Chloroform-d) $\delta 8.29(\mathrm{~d}, J=9.0 \mathrm{~Hz}, 2 \mathrm{H}), 7.40(\mathrm{~d}, J=9.0 \mathrm{~Hz}, 2 \mathrm{H}), 4.20(\mathrm{t}, J=6.3$ $\mathrm{Hz}, 2 \mathrm{H}), 2.10-1.99$ (m, 3H), 1.90 (t, $J=6.3 \mathrm{~Hz}, 2 \mathrm{H}), 1.72$ (t, $J=7.3 \mathrm{~Hz}, 2 \mathrm{H})$.

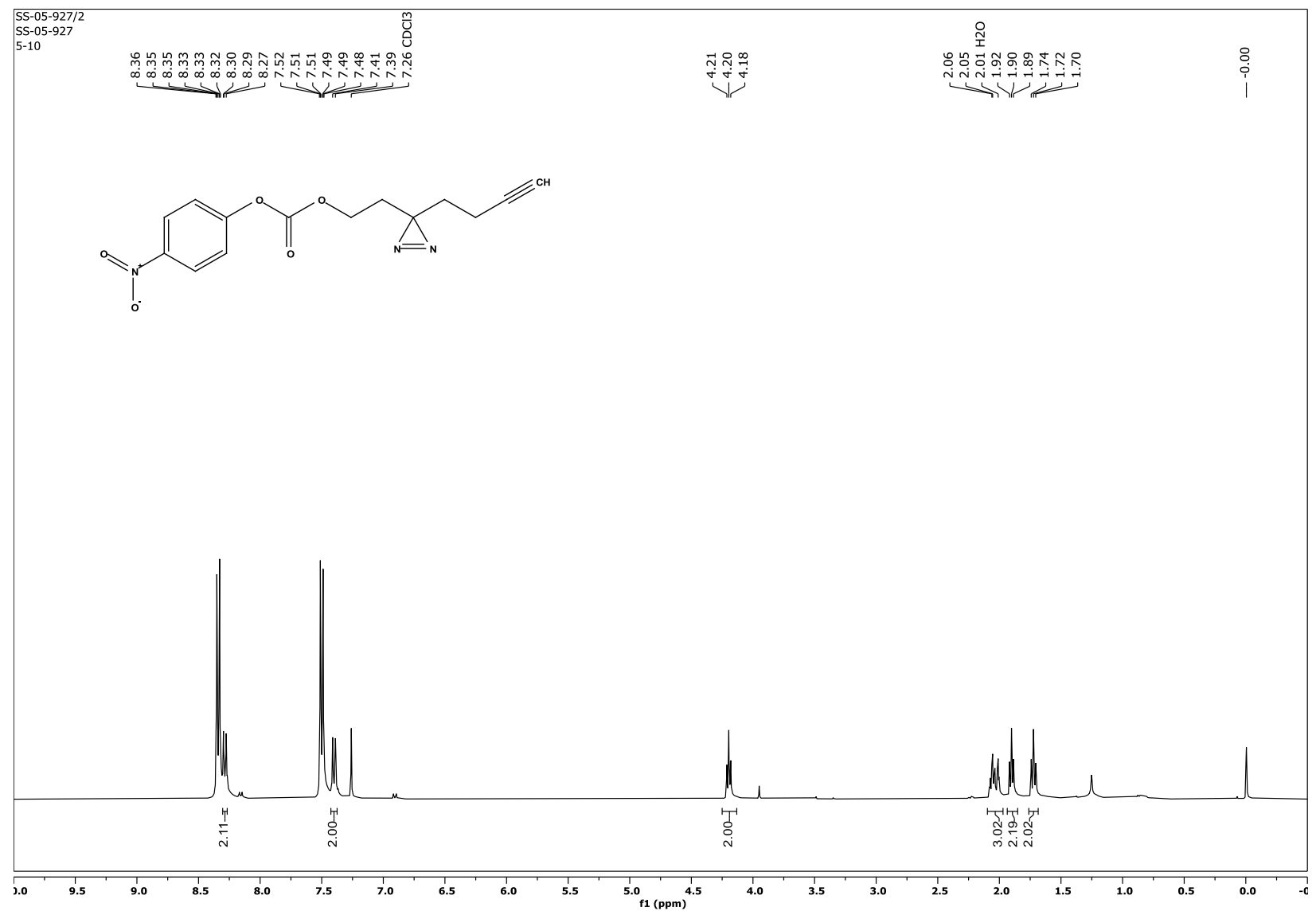




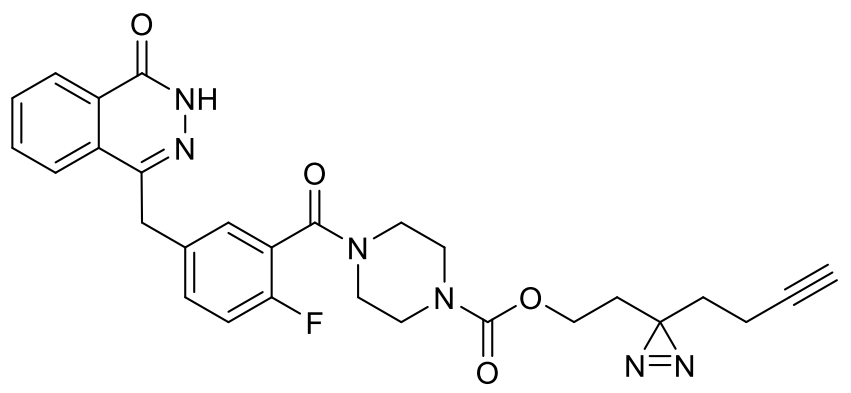

ad-olaparib

4-(4-fluoro-3-(piperazine-1-carbonyl)benzyl)phthalazin-1(2H)-one P2 (7.5 mg, $0.02 \mathrm{mmol}$ ) and 2-(3-(but3-yn-1-yl)-3H-diazirin-3-yl)ethyl (4-nitrophenyl) carbonate $\mathbf{i}(6.0 \mathrm{mg}, 0.02$, 1.0equvi) were dissolved in anhydrous DMF $(0.4 \mathrm{~mL})$. TEA $(40 \mu \mathrm{L}, 0.028 \mathrm{mmol}, 1.4$ equiv.) was added and the reaction was left to stir overnight at room temperature. Up on reaction completion monitored by TLC, it was quenched with water $(1.0 \mathrm{~mL})$ and extracted with ethyl acetate $(2 \times 5 \mathrm{~mL})$. The ethyl acetate was then washed with brine $(3 \times 5$ $\mathrm{mL}$ ). The organic layer was then passed through a silica plug, dried over $\mathrm{MgSO}_{4}$, and concentrated to yield white solid (9.6mg, 89\%).

${ }^{1}$ H NMR (400 MHz, Chloroform- $\left.\boldsymbol{d}\right) \delta 10.37(\mathrm{~s}, 1 \mathrm{H}), 8.60-8.33(\mathrm{~m}, 1 \mathrm{H}), 7.81-7.67(\mathrm{~m}, 3 \mathrm{H}), 7.37$ $7.27(\mathrm{~m}, 2 \mathrm{H}), 7.04(\mathrm{t}, J=8.7 \mathrm{~Hz}, 1 \mathrm{H}), 4.28(\mathrm{~s}, 2 \mathrm{H}), 4.03(\mathrm{t}, J=6.1 \mathrm{~Hz}, 2 \mathrm{H}), 3.79(\mathrm{br}, 2 \mathrm{H}), 3.60(\mathrm{br}, 2 \mathrm{H})$, 3.47 (br, 2H), 3.31 (br, 2H), $2.07-1.94$ (m, 3H), $1.80-1.75$ (m, 2H), $1.69-1.64$ (m, 2H). LR-MS (ESI) $\mathrm{m} / \mathrm{z}[\mathrm{M}]^{+}$calculated for $\mathrm{C}_{28} \mathrm{H}_{27} \mathrm{FN}_{6} \mathrm{O}_{4}, 530.2$ observed 530.7 .

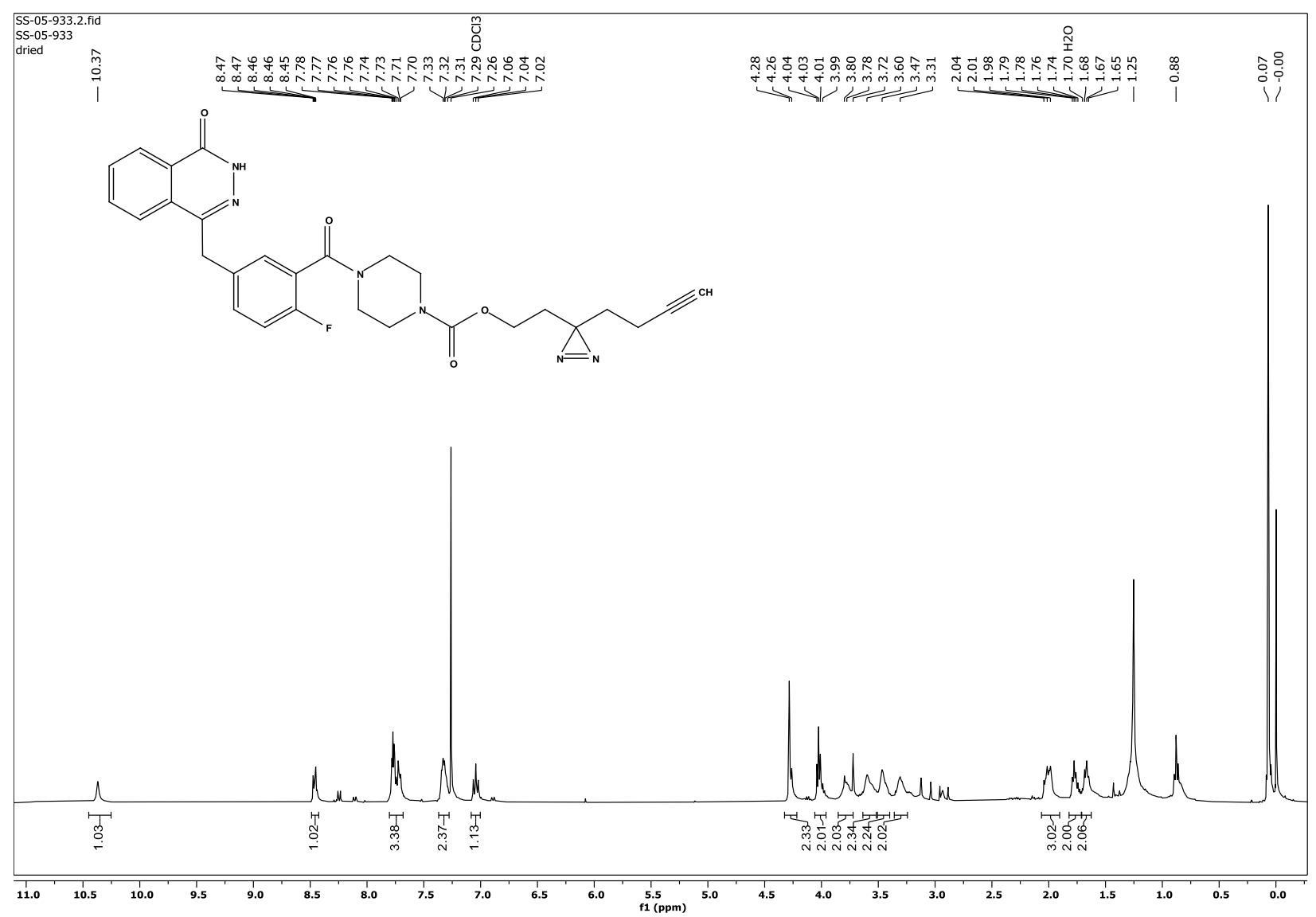




\section{References}

(1) Carter-O’Connell, I.; Jin, H.; Morgan, R. K.; David, L. L.; Cohen, M. S. Engineering the Substrate Specificity of ADP-Ribosyltransferases for Identifying Direct Protein Targets. J. Am. Chem. Soc. 2014, 136 (14), 5201-5204. https://doi.org/10.1021/ja412897a.

(2) Kirby, I. T.; Kojic, A.; Arnold, M. R.; Thorsell, A. G.; Karlberg, T.; Vermehren-Schmaedick, A.; Sreenivasan, R.; Schultz, C.; Schüler, H.; Cohen, M. S. A Potent and Selective PARP11 Inhibitor Suggests Coupling between Cellular Localization and Catalytic Activity. Cell Chem. Biol. 2018, 25 (12), 1547-1553.e12. https://doi.org/10.1016/j.chembiol.2018.09.011.

(3) Eng, J. K.; Jahan, T. A.; Hoopmann, M. R. Comet: An Open-Source MS/MS Sequence Database Search Tool. Proteomics 2013, 13 (1), 22-24. https://doi.org/10.1002/pmic.201200439.

(4) Wilmarth, P. A.; Riviere, M. A.; David, L. L. Techniques for Accurate Protein Identification in Shotgun Proteomic Studies of Human, Mouse, Bovine, and Chicken Lenses. J. Ocul. Biol. Dis. Infor. 2009, 2 (4), 223-234. https://doi.org/10.1007/s12177-009-9042-6.

(5) Keller, A.; Nesvizhskii, A. I.; Kolker, E.; Aebersold, R. Empirical Statistical Model to Estimate the Accuracy of Peptide Identifications Made by MS/MS and Database Search. Anal. Chem. 2002, 74 (20), 5383-5392. https://doi.org/10.1021/ac025747h.

(6) Kleiner, P.; Heydenreuter, W.; Stahl, M.; Korotkov, V. S.; Sieber, S. A. A Whole Proteome Inventory of Background Photocrosslinker Binding. Angew. Chemie Int. Ed. 2017, 56 (5), 13961401. https://doi.org/10.1002/anie.201605993.

(7) Krohn, K.; Heins, H.; Wielckens, K. Synthesis and Cytotoxic Activity of C-Glycosidic Nicotinamide Riboside Analogs. J. Med. Chem. 1992, 35 (3), 511-517. https://doi.org/10.1021/jm00081a012.

(8) Bonnac, L. F.; Gao, G. Y.; Chen, L.; Patterson, S. E.; Jayaram, H. N.; Pankiewicz, K. W. Efficient Synthesis of Benzamide Riboside, a Potential Anticancer Agent. Nucleosides, Nucleotides and Nucleic Acids 2007, 26 (10-12), 1249-1253. https://doi.org/10.1080/15257770701528222. 